\title{
Parenting across borders : effects of transnational parenting on the lives of Angolan and Nigerian migrant parents in The Netherlands
}

Citation for published version (APA):

Haagsman, R. K. (2015). Parenting across borders : effects of transnational parenting on the lives of Angolan and Nigerian migrant parents in The Netherlands. [Doctoral Thesis, Maastricht University]. Datawyse / Universitaire Pers Maastricht. https://doi.org/10.26481/dis.20150410rh

Document status and date:

Published: 01/01/2015

DOI:

10.26481/dis.20150410rh

Document Version:

Publisher's PDF, also known as Version of record

Please check the document version of this publication:

- A submitted manuscript is the version of the article upon submission and before peer-review. There can be important differences between the submitted version and the official published version of record.

People interested in the research are advised to contact the author for the final version of the publication, or visit the DOI to the publisher's website.

- The final author version and the galley proof are versions of the publication after peer review.

- The final published version features the final layout of the paper including the volume, issue and page numbers.

Link to publication

\footnotetext{
General rights rights.

- You may freely distribute the URL identifying the publication in the public portal. please follow below link for the End User Agreement:

www.umlib.nl/taverne-license

Take down policy

If you believe that this document breaches copyright please contact us at:

repository@maastrichtuniversity.nl

providing details and we will investigate your claim.
}

Copyright and moral rights for the publications made accessible in the public portal are retained by the authors and/or other copyright owners and it is a condition of accessing publications that users recognise and abide by the legal requirements associated with these

- Users may download and print one copy of any publication from the public portal for the purpose of private study or research.

- You may not further distribute the material or use it for any profit-making activity or commercial gain

If the publication is distributed under the terms of Article $25 \mathrm{fa}$ of the Dutch Copyright Act, indicated by the "Taverne" license above, 
๑ Copyright Maastricht 2015, Karlijn Haagsman | Alle rechten voorbehouden. Niets uit deze uitgave mag worden verveelvoudigd, opgeslagen in een geautomatiseerd gegevensbestand of openbaar gemaakt worden in enige vorm of op enige wijze, hetzij elektronisch, mechanisch of door fotokopieën, opname, of op enige andere manier, zonder voorafgaande schriftelijke toestemming van de auteur.

(c) Copyright Maastricht 2015, Karlijn Haagsman | All rights reserved. No part of this publication may be reproduced, stored in a retrieval system, or transmitted, in any form or by any means, electronic, mechanical, photocopying, recording, or otherwise, without the prior permission in writing from the proprietor.

Cover design: Els Haagsman | www.elshaagsman.com

Printed by: Datawyse | Universitaire Pers Maastricht 


\title{
Parenting across borders
}

\author{
Effects of transnational parenting on \\ the lives of Angolan and Nigerian migrant parents \\ in The Netherlands
}

DISSERTATION

to obtain the degree of Doctor at Maastricht University, on the authority of the Rector Magnificus, Prof. dr. L. L. G. Soete,

in accordance with the decision of the Board of Deans, to be defended in public on Friday, 10 April 2015 at 10:00 hrs.

by

RENSKE KARLIJN HAAGSMAN 


\section{SUPERVISOR}

Prof. dr. V. Mazzucato

\section{CO-SUPERVISOR}

Dr. B. Dito

\section{ASSESSMENT COMMITTEE}

Prof. dr. T. Conzelmann (Chair)

Prof. dr. E. Graham

Dr. M. Lubbers

Dr. M. Siegel

This dissertation has received funding from the New Opportunities for Research Funding Co-operation Agency in Europe (NORFACE) Research Programme 'Migration in Europe - Social, Economic, Cultural and Policy Dynamics' [NORFACE grant number 315]. 


\section{Contents}

$\begin{array}{ll}\text { Acknowledgements } & 9\end{array}$

CHAPTER 1. Introduction $\quad 15$

$\begin{array}{lll}1.1 & \text { Research problem } & 17\end{array}$

1.2 Migration \& Transnationalism studies 23

$\begin{array}{lll}1.3 & \text { Transnational families } & 26\end{array}$

1.3.1 The emergence of transnational family studies 26

1.3.2 Causes for transnational family separation 27

1.3.3 Parenting across borders and its consequences $\quad 29$

1.3.4 Contribution to transnational family studies 32

1.5 Overview of the dissertation 33

CHAPTER 2. Angolans and Nigerians in The Netherlands 37

2.1 Introduction 39

2.2 A short history of migration to The Netherlands 39

2.2.1 Angolan migration 40

2.2.2 Nigerian migration $\quad 42$

2.3 Recent developments in immigration law 44

2.3.1 Vreemdelingenwet $\quad 44$

2.3.2 Dutch asylum and refugee law 46

2.4 Angolans and Nigerians in The Netherlands 48

2.4.1 Demographic and migration statistics of Angolans and Nigerians in The Netherlands 48

2.4.2 Labour market position of Angolans and Nigerians in The Netherlands 51

2.5 Conclusion 53

CHAPTER 3. Data, methodology \& sample characteristics 55

$\begin{array}{lll}3.1 & \text { Introduction } & 57\end{array}$

3.2 Data \& methods $\quad 57$

3.2.1 Sampling procedure $\quad 57$

$\begin{array}{ll}3.2 .2 & \text { The questionnaire } \\ 3.2 .3 & 60\end{array}$

3.2.3 Methods $\quad 62$

$\begin{array}{lll}3.3 & \text { Sample characteristics } & 63\end{array}$

3.3.1 Socio-demographic characteristics sample $\quad 63$

3.3.2 Migration pattern respondents $\quad 66$

$\begin{array}{ll}\text { 3.3.3 Respondents' labour market participation } & 67\end{array}$

$\begin{array}{lll}3.4 & \text { Transnational family characteristics } & 69\end{array}$

\begin{tabular}{ll}
3.4 .1 & Reasons for transnational separation \\
\hline
\end{tabular}

$\begin{array}{ll}3.4 .2 & \text { Parenting across borders } \\ \end{array}$ 
CHAPTER 4. Quality of parent-child relationships in transnational families

4.1 Introduction

$\begin{array}{llr}4.2 & \text { Literature review } & 84\end{array}$

4.2.1 Gender 84

4.2.2 The amount of contact and remittances 85

4.2.3 The caregiver $\quad 86$

4.2.4 Length of separation $\quad 87$

4.2.5 Age of child and age at separation $\quad 87$

4.3 Angolan and Nigerian migrants in The Netherlands 89

4.4 Data and methods 91

$\begin{array}{lll}\text { 4.4.1 Data } & 91\end{array}$

4.4.2 Measures $\quad 92$

4.4.3 Descriptive statistics $\quad 92$

$\begin{array}{lll}\text { 4.4.4 Statistical analyses } & 93\end{array}$

$\begin{array}{lll}4.5 & \text { Results } & 94\end{array}$

$\begin{array}{lll}4.5 .1 & \text { Gender } & 94\end{array}$

$\begin{array}{ll}\text { 4.5.2 Contact and remittances } & 94\end{array}$

\begin{tabular}{ll}
4.5 .3 & Caregiver \\
\hline
\end{tabular}

4.5.4 Length of separation. $\quad 96$

4.5.5 Age at separation and age of child. 96

$\begin{array}{ll}\text { 4.5.6 Control variables } & 96\end{array}$

$\begin{array}{lll}\text { 4.6 Discussion and conclusion } & 97\end{array}$

CHAPTER 5. Subjective well-being of transnational parents $\quad \mathbf{1 0 1}$

$\begin{array}{lll}5.1 & \text { Introduction } & 103\end{array}$

$\begin{array}{lll}5.2 & \text { Theoretical background } & 104\end{array}$

$\begin{array}{llr}\text { 5.2.1 Transnational families } & 104\end{array}$

$\begin{array}{ll}\text { 5.2.2 Migrant well-being } & 105\end{array}$

5.3 Angolans and Nigerians in The Netherlands 106

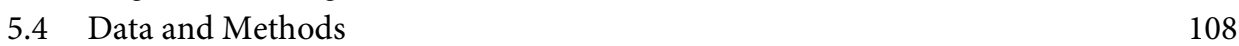

$\begin{array}{ll}\text { 5.4.1 Data } & 108\end{array}$

\begin{tabular}{lr}
5.4 .2 & Dependent variables \\
\hline 5.4 .3 & 108
\end{tabular}

$\begin{array}{ll}5.4 .3 & 109\end{array}$

$\begin{array}{ll}5.4 .4 & \text { Control variables } \\ 5.4 .5 & 109\end{array}$

$\begin{array}{lll}\text { 5.4.5 Socio-demographic characteristics } & 110\end{array}$

$\begin{array}{ll}\text { 5.4.6 Analytical strategy } & 111\end{array}$

$\begin{array}{lll}5.5 & \text { Results } & 112\end{array}$

$\begin{array}{lll}5.5 .1 & \text { Health } & 115\end{array}$

$\begin{array}{ll}\text { 5.5.2 Mental health status } & 115\end{array}$

$\begin{array}{lll}5.5 .3 & \text { Happiness } & 115\end{array}$

$\begin{array}{ll}\text { 5.5.4 Life satisfaction } & 115\end{array}$

$\begin{array}{lll}5.6 & \text { Discussion } & 116\end{array}$ 
CHAPTER 6. Job outcomes of transnational parents

$\begin{array}{lll}6.1 & \text { Introduction } & 123\end{array}$

$\begin{array}{ll}\text { 6.2 Work and family life } & 124\end{array}$

$\begin{array}{ll}\text { 6.2.1 Work-family conflict } & 124\end{array}$

6.2.2 Happy productive worker thesis 126

$\begin{array}{lll}6.3 & \text { Migration context } & 127\end{array}$

$\begin{array}{ll}\text { 6.4 Data \& analysis } & 129\end{array}$

$\begin{array}{lll}6.4 .1 & \text { Variable constructions } & 130\end{array}$

$\begin{array}{ll}\text { 6.4.2 Analytical strategy } & 131\end{array}$

$\begin{array}{llr}6.5 & \text { Results } & 133\end{array}$

6.5.1 Mediation analysis 134

6.5.2 Analysis with transnational parents 136

$\begin{array}{ll}\text { 6.6 Discussion and conclusions } & 138\end{array}$

CHAPTER 7. Conclusions $\quad 143$

$\begin{array}{lll}7.1 & \text { Introduction } & 145\end{array}$

$\begin{array}{lll}7.2 & \text { Main empirical findings } & 146\end{array}$

$\begin{array}{ll}7.3 \text { Contributions to literature } & 150\end{array}$

7.3.1 The transnational approach and families 150

7.3.2 Intersections of socio-economic status, legal status and transnational parenting 151

7.3.3 Focus transnational mothers and fathers 152

7.4 Future research and policy implications 153

$\begin{array}{ll}\text { References } & 157\end{array}$

Nederlandse samenvatting (summary in Dutch) 167

1 Introductie 169

2 Resultaten 170

3 Conclusie 172

$\begin{array}{ll}\text { Valorisation addendum } & 175\end{array}$

1 Policy implications $\quad 177$

2 Dissemination of results 180

$\begin{array}{ll}\text { Curriculum Vitae } & 181\end{array}$ 

Acknowledgements 
This dissertation is the product of a long journey which did not commence at my employment by Maastricht University but much longer ago. In this journey I have had the pleasure to meet many people who, without knowing, have led me to become the researcher I am today.

My career as an academic researcher started at home. How could it otherwise in a family full of academics? My father a biochemist with a chair in Molecular Host defence and my mother a biologist who preceded me by defending her dissertation five years ago. At home my two sisters and I were stimulated to gain knowledge, learn and ask (critical) questions. And I asked many questions; I am sure it drove them crazy at times. But they always helped me to look for answers. Especially my mother acted as a real Wiekepedia by looking up answers with me. Although I chose quite another discipline, politics and science were always topic of discussion at the dining table. Though I must say that when it was on biology, chemistry or veterinary science, and it was often, I was often lost. My parents also sparked interest in various topics by taking us to museums, providing us with science books, magazines (my favorite at the time being 'The National Geographic') and by travelling through various places. One of these trips sparked my interest in migration. It was in Ireland where we visited a museum on the Irish famine and the resulting mass migration to the U.S. This trip resulted a year later in my profielwerkstuk or high school paper. Having this home environment eventually led all three daughters to be scientists and all are at the moment employed by a university. Nonetheless my parents always let me take my own path and stimulated me to follow my own interests, which is why I ended up studying Cultural Anthropology. I am grateful to my parents for this safe home environment, but also in the support they have given me throughout my life and academic career. Without your upbringing and support I would never be where I am now. Lieve papa en mama jullie zijn mijn steun en toeverlaat.

My two sisters, Annika and Marjolein, are my best friends and have been very important in my life. You are the ones who understand me best and have always been there to provide comfort when I needed it. The trips to the sauna, theater, our dinners, zussenweekenden, and our many travels have given me the relaxation that I needed during this journey. Lieve Annika en M, ik hoop dat we nog veel zussenweekenden zullen hebben en vele reizen zullen gaan maken. Immers, we zijn allemaal deel van de academische wereld en kunnen af en toe wel een break gebruiken.

My grandparents also play an important part in my life. Unfortunately, I lost one grandmother at the beginning of this $\mathrm{Ph}$. D. journey and a grandfather at the end. Oma Wies and Opa that does not mean that you are not in my heart. Pake, je vraagt altijd of ik wat vaker op bezoek kan komen en ik weet dat ik dat door mijn verhuizing naar Maastricht niet genoeg heb gedaan. Maar als ik op Schier was, was het heerlijk om je te 
zien en uit te waaien. Oma Riet, je hebt altijd laten blijken hoe trots jij bent op al je kinderen en kleinkinderen en ik waardeer dat zeer. Ook gaf jij mij al jong het advies: “eerst je carrière dan pas de man!". Ten slotte, tante Els, ik vind het een enorme eer dat je de voorkant van mijn dissertatie hebt ontworpen en geschilderd. Ik dank je zeer.

In Nijmegen I took my first steps as a researcher as a student of Cultural Anthropology and have met my best friends. Friends I will have for life. Stuupke Inc, mijn mentorzusjes, I know you have seen less of me since I started working in Maastricht but the bond we established in Nijmegen has always remained. You have helped me during my $\mathrm{Ph}$. D. in several ways. Not only practically, as some of you have helped me with checking questionnaires and entering data, but also emotionally. Whenever I was struggling you were always there for me. We also planned many nice events and trips together that brought me the peace I needed. Anke, Marieke, Lieke, Rosalijne en Jolien, ook al wonen we verspreid over het hele land jullie zijn mijn homies. Also het 21ste bestuur der N.S.V.A. Quetzalcoatl, Rosalijne, Christa and Lieke, I want to thank you for all the nice weekends and sailing trips we had the last few years. Also, it was wonderful to celebrate the end my Ph. D with you last summer by going on a holiday to Croatia.

Jolien I want to especially thank you here. Through our common interests we have taken all our steps in our academic career together. Without you I would not have ended up in migration research. We did a Bachelor and two Masters together and our common interests led us both to do fieldwork in islands in the Pacific. Even while we were on two far away islands at the time, you stimulated me to join you half a year later in Utrecht for the research master and eventually to apply for a $\mathrm{Ph}$. $\mathrm{D}$. And here we are, both doing our $\mathrm{Ph}$. D. in migration research. I love the discussions we have about migration research and hope that we can take many more steps in our academic career together.

My next step in my academic career took me to Utrecht where I studied Migration, Ethnic Relations and Multiculturalism. Here my fellow students and the staff of ERCOMER have prepared me for a life as an academic researcher. And, not unimportantly, I met Özge. Without her I would not stand here today and that is also why she is my paranymph. Özge not only did you direct me to this Ph. D. position, I would have not been able to go through this journey without you. I know I do not show my emotions that often, so maybe I do not express it enough, but I am very grateful for all that you have done for me in Maastricht. I hope that we will continue this journey together now we are both employed by the University of Maastricht. I look forward to many more evenings spend at Lumiere or Café Zondag.

When I arrived at this Faculty the first person welcoming me with open arms was Kim. Kim, also without you I would have never been able to finish this dissertation. You had 
been appointed to act as my buddy, but have really become one in the past five years. I could consult you for everything, from statistics to personal issues. There are so many things you did for me; too many to mention. I feel like you have taken me up in your home and I have spent many evenings at your house. I have felt so much at home that I took over your house when you moved to The Hague. I do not know how to extend my gratitude, but maybe the fact that you are my paranymph shows how grateful I am.

At the faculty of Arts and Social Sciences in Maastricht I got to know many great colleagues and made new friends who made me feel at home in Maastricht. First I want to thank my roommates Kim, Koen, Miranda and Nicolle with whom there was never a dull moment in the office. Second, thanks go out to my colleagues in the C-building such as Joeri, Marijke and Claudia, with whom I spent many nice breaks in the FASoS garden. Third, I want to thank the secretariat, in particular Sabine, whom have assisted me throughout my research. Without you Sabine I would have never been able to deal with all the administrative issues that are involved with doing survey research such as paying the many interviewers hired. I am very grateful for all your wonderful assistance. Fourth, I want to thank the members of the TMG group, which always provided me with valuable feedback in work-in-progress meetings and helped me grow as a researcher. Kim, Miranda, Natalia, Marieke, Michaela, Bilisuma, Elsje and Joan: not only were you valuable colleagues you also have become my friends. Fifth, I got to work with a great team of teachers and researchers in the GTD group. I loved teaching in the Globalization and Development minor and in the Master of Globalization and Development. Chris, Wiebe, Lou, Bernike, Valentina, Bilisuma, Julia and Elsje I am honored to be part of such a great team and I am happy I can continue working with you.

Simone, Joan and Hortense, my mac gym buddies, thank you for joining me in the gym. Our sport sessions have been a great outlet when I was frustrated with research or teaching. Marrit, ik weet dat we elkaar minder zagen dan we wilden door mijn promotiewerk en mijn verhuizing naar Maastricht, maar altijd als je bij mij in Maastricht kwam voor een weekendje kwam ik helemaal tot rust. Eefje, thank you for the great dinners cooked and the nights in which we had long conversations over a glass of wine. It was great to celebrate all my $\mathrm{Ph}$. $\mathrm{D}$. milestones with you. I have prosecco for us in the fridge to celebrate this one. Julia, you came only in my life at the end of the Ph. D., but you helped me across the finish line. In you I have found a great friend and soul mate. You were always able to keep my spirits up. I miss our gym sessions, your enthusiasm and our crazy nights. I hope to visit you in San Fransisco soon, but know there is always a la chouffe waiting for you here. And finally, the migration crew: Kim, Tom, Marieke, Orçun, Sonja and Rik. Although you all knew each other through the research master in Nijmegen you took me into your group with open arms. You have all moved to The Hague now and I miss you a lot. I miss our great nights together at Tribunaal and 
Zondag and Kim I also miss your egg baking skills in the middle of the night! You all have made my stay in Maastricht a wonderful experience. Know there is always room for you in my bed \& breakfast.

I would also like to thank NORFACE for funding my dissertation through the TCRAfEu project. Through this TCRAf-Eu project I got to work with a great team of international researchers. I want to especially mention Miranda with whom I started this $\mathrm{Ph}$. D. journey together and with whom I had many valuable discussions about our research and findings. Also, I want to extend my gratitude to Djamila who left us in the middle of this journey but has provided me with a good beginning. I have learned a lot from the questionnaire development, interview training and the fieldwork. And as they say een goed begin is het halve werk.

I also want to thank the members of the assessment committee, Prof. dr. Thomas Conzelmann, Prof. dr. Elspeth Graham, dr. Marcel Lubbers and dr. Melissa Siegel for reading my dissertation and providing their valuable feedback.

Not unimportantly, I also want to express my gratitude to all the interviewers and research assistants that helped me conduct the fieldwork and enter the data. But most importantly, I want to thank the respondents, as without you my research would not have been possible. Thank you for your time and providing us with your life stories. It is highly appreciated.

Last but not least, I want to thank my supervisors Prof. dr. Valentina Mazzucato and dr. Bilisuma Dito. Dear Bilisuma, although you became my daily supervisor halfway through my Ph. D trajectory, you have helped me enormously. Thank you for your valuable feedback on my papers and other work. You gave me the guidance and confidence I needed to finish this $\mathrm{Ph}$. D. You helped me grow. I think we make a great team as teachers and researchers. And last, dear Valentina thank you for your confidence in me. You have transformed me from a student into an academic researcher. You have been patient with me and always encouraged me to do better. Your extensive and valuable feedback and thoroughness have enabled me to write this dissertation and grow. Finally, I want to thank you for providing me with many opportunities to grow further. Valentina and Bilisuma, this dissertation is a milestone but not the end of a journey. I am delighted we are able to continue our collaboration in research.

As always, as many of my friends and family have indicated, I talk too much. Though there are many people I did not mention, such has my huge and lovely extended family, I will end it here. For all my other friends, family and people that came onto my path I did not mention, I did not forget you. You are all in my heart. 

CHAPTER 1.

\section{Introduction}





\subsection{Research problem}

"I feel so bad, because the [Dutch] law says when the children are above 18 you cannot bring them here. And that make me go crazy earlier times. I never grow up with my children and it does not make me feel fine. [...] Before they were 18, I was not qualified for it, in the sense that I was not having a job or I was not having [the proper documents]. [...] One time in the Netherlands I was treated for, I was having a depression, because of my situation back home. I was very very very depressed. I was on medication for a very long time" (John, father of three, age 56, February 2013).

"We talk from time to time like friends [...] Actually, we talk about everything, everything [...] The only thing is we cannot see ourselves face to face on the phone, but we discuss everything [...] At times you know, you need to, you feel like to hold them, you feel like to feed them, you know. At times when they are a little bit sad, when they are not happy [...] Those things cannot happen on the phone". "So, how does it make you feel that you want to hug them, but that it is not possible?" "Awful. Uh, I tell them on the phone if I tell you something, will you believe me? What what what, do they say. I'm missing you anyway. Oh they say, you are missing me, you are missing me, you know [...] Baby I love you, always remember that. And then they say, we love you too mummy [...] It's tough. But I don't have a choice. It is a little bit tough." (Francis, mother of three, age 44, March 2013).

John is a Nigerian father who migrated to The Netherlands while his three children, between the ages of 7 and 12, remained in Nigeria in the care of their mother. Although he wanted to bring his children over to The Netherlands once he had the right documents, by the time he obtained a residence permit, the children were too old to be entitled to family reunification. Although he occasionally visits his children in Nigeria, they have been living apart for 18 years now. John indicated in the interview that his youngest son was not doing well and would have especially loved to bring him to The Netherlands. He is having difficulties with his son, because he does not listen to him and has dropped out of high school. John worries a lot about this son and feels helpless.

Francis is a Nigerian mother who left her twins in the care of her mother when they were 8 months old. Today they are 17 and live with her sister. Francis is satisfied with the care her children receive in Nigeria, and indicates that through regular contact and visits both in Nigeria and The Netherlands she is able to maintain a close relationship with her daughters; they interact almost like friends. Therefore, she said that although 
she prefers to have them around her and they miss each other, she wants them to stay in Nigeria for now and finish their education.

Both John and Francis are part of a so-called transnational family: a family whose members live in two or more nation-states and whose kinship ties, as a result, extend across national borders. Though the term transnational family can pertain to having any member of the family abroad, when I use the term in this dissertation it concerns one or both parents who migrate while some or all of their children under the age of 21 remain in the country of origin. John and Francis' quotes illustrate the difficulties migrant parents in these families can have with parent-child separation. They both said they miss their children and find separation tough. However, while Francis misses her girls and finds separation occasionally hard, she was satisfied with the care arrangements she made with her sister and with how her children were doing in Nigeria. This cannot be said for John who was struggling with the separation because his youngest was not doing well. The separation clearly impacted his life in The Netherlands; he had to be treated for depression, which resulted from parent-child separation.

Although there are many transnational families in today's world, we still know little of the impact these transnational separations have on these migrant parents. Is John's story, with severe impacts on his emotional well-being, a common story or an exception? Or is Francis' story more common in which no severe implications on well-being were reported and the arrangements she made for childcare were working well? What was the main cause of John's poor emotional well-being, the separation itself or were there other factors at play? And does his poor emotional well-being impact on other areas of his life? This dissertation investigates the impact that transnational parent-child separation has on migrant parents' well-being in The Netherlands. I study their wellbeing by taking a transnational approach, which enables me to look beyond the nationstate and take into account family life that crosses national borders.

Though multi-local families have existed for centuries, increased global connections have changed the nature and scope of these transnational families. Some authors suggest that, as a result of the rise of the information society, modern technology, capitalist production, and international migration, the number of parent-child separations has grown in the last decade (Dreby, 2007; Schmalzbauer, 2004), However, exact numbers of transnational families worldwide are unknown. Although there are only educated guesses on the number of transnational families globally, the number of families, especially those in which parents and underage children live separately, reported to live geographically dispersed because of migration is astonishingly high. For example, Save the Children (2006) roughly estimates that up to 1 million Sri Lankan children have a migrant mother living abroad. UNICEF and the IOM calculated that in Moldova 117 thousand children under 18 years of age have at least one parent working abroad (Salah, 2008). According to non-governmental organisations in the Philippines nine million Filipino children grow up separated from one or both of their parents, 
which is 27 percent of all Filipino children (Kakammpi in Parreñas, 2005). Lastly, a study by Suarez-Orozco, Todorova, and Louie (2002) on 385 migrant youths in Boston and San Francisco indicated that 85 percent of them was separated from one or both parents during the migration process.

Because these numbers are rough estimates and display no trends, we therefore do not know with any certainty whether these types of families have grown. The numbers do indicate that at present a large share of parents and children live separated from one another due to migration. Yet, more important than the number of transnational families is the effect this type of family separation has on those involved. Although this type of family separation is a longstanding phenomenon, scholars have only recently started to investigate the effects of this separation. The reports above (Salah, 2008; Save the Children, 2006) and the majority of transnational family studies point to the difficulties that parents and children experience because of transnational separation.

Research shows that both parents and children can feel emotional loss and display depressive and stress symptoms as a result of the separation. Ethnographic accounts of transnational parent-child separation indicate that parent-child relationships often suffer due to geographical separation. Some children in these studies stated that they felt less close to their transnational parent after separation because of the lack of regular physical contact (Coe, 2008). Additionally, parents reported that, while they keep parenting across borders, emotional gaps arise between them and their children (Fresnoza-Flot, 2009). Some parents, such as John, left when their children were small and were unable to build a solid relationship before departure. For these parents, it is often difficult to see their children be more attached to their caregivers and even more challenging when their children react with indifference during visits (Banfi \& Boccagni, 2011; Fresnoza-Flot, 2009). As John's example indicates, some parents feel that they lose parental authority when separation lengthens, leading to possible tension and conflict (Boccagni, 2012).

As a result of this loss of intimacy and their longing for their children, parents' emotional well-being has been affected; parents feel alone and disempowered, and, especially in child-related crises such as the illness of a child, parents can feel hopeless and powerless (Mazzucato, 2011). In addition, as a result of given parenting ideologies, the difficulties with separation that children express, and the resulting accusations that children make, many transnational parents feel guilty, ashamed and embarrassed about 'abandoning' their children (Banfi \& Boccagni, 2011; Bernhard, Landolt, \& Goldring, 2009; Boccagni, 2012; Carling, Menjívar, \& Schmalzbauer, 2012; Parreñas, 2005; Zentgraf \& Chinchilla, 2012). In parallel with anthropologists and sociologists, psychologists have established an association between family separation and immigrant mental health (Horton, 2009; Suarez-Orozco et al., 2002), but this research has remained limited. As indicated above, children are also impacted by the separation. Some children feel lonely and abandoned because of the separation, resulting in low emotional well-being and 
health, and children in transnational families have been found to display behavioural problems and perform less well at school in comparison to their peers (Dreby, 2007; Dreby \& Stutz, 2012; Heymann et al., 2009; Jia \& Tian, 2010; Parreñas, 2005; Smith, 2006; Wen \& Lin, 2012). Thus, the studies cited above seem to indicate that transnational separation has several severe consequences.

With this dissertation I aim to contribute to the study of transnational parenthood and well-being in several ways. First, this study will focus on different aspects of transnational parents' well-being, not all of which have been explored before. I will investigate three aspects of parental well-being that are intrinsically related to each other, namely, the parent-child relationship, subjective well-being and the job performance of these migrant parents. Essential to understanding transnational parenting is studying the constraints of physical separation and how parent-child relationships work under these constraints, especially because ethnographic studies suggest that the quality of the parent-child relationship is important for the well-being of both parent and child. As noted above, if parents feel that the relationship is deteriorating, it can lead to feelings of hopelessness, loneliness, and emotional loss, hence affecting the emotional well-being of the parent. That is why I first study which factors are associated with the quality of the transnational parent-child relationship to understand how transnational child raising arrangements function under certain conditions.

Subsequently, taking these relationships into account, I study the subjective wellbeing of transnational parents, which the literature suggests is an area that is particularly impacted by transnational separation. Finally, I study how the parent-child separation and its potential consequences for the parent-child relationship and subjective wellbeing are associated with labour market outcomes. Labour market outcomes are especially important for transnational parents because economic benefits of this labour are an important reason why some parents migrate. And, several studies indicate the importance of remittances, the fruits of this labour, for maintaining family relations (Dreby, 2006; Dreby \& Adkins, 2010; Zentgraf \& Chinchilla, 2012). This is an area that has not yet been investigated by transnational family scholars, despite the fact that organisational psychology leads us to believe that there are multiple ways in which transnational separation and labour market outcomes could be related. In sum, these are three areas that are likely to be affected by transnational family life and to shape the life chances of parents in the host country.

Second, I will investigate these different outcomes by making use of and connecting multiple disciplines: migration and family sociology, cultural anthropology and social and organisational psychology. These different disciplines have all shed light on different aspects of migration and the family but often do not draw from one another to build new frameworks of study. To enhance a better understanding of contemporary families, we need to bring these disciplines together and let them speak to each other because families are shaped by various economic, political, legal and social processes that are the 
focus of research in these various disciplines (Kraler, Kofman, Kohli, \& Schmoll, 2011). In this dissertation I will tie research from these different fields to the study of transnational families, which is currently predominantly based in anthropology and gender studies. This allows me to take factors into account that the migrant well-being literature and organisational psychology literature indicate to be of importance for migrant well-being and labour market performance, but that transnational family scholars have not yet incorporated in their studies. And vice versa, I take important factors into account that transnational family scholars have identified, but have not yet been incorporated in the migrant well-being literature. Additionally, connecting findings from these multiple disciplines allows me to build a framework that looks at the effects of transnational family life from both a transnational, host and origin country perspective. As such, an innovative theoretical perspective on the effects of transnational family life is provided, that suggests important factors that one needs to take into account when investigating transnational parental well-being.

Third, though the amount of research on transnational parents is growing, there are almost no quantitative data on the extent nor systematic evidence for the effects that transnational family life has on parents' lives (Mazzucato \& Schans, 2011). The mostly small-scale ethnographic studies referred to above have revealed that transnational families or families in general are not homogenous units; they vary by class, ethnicity, employment opportunities, legal status, and so forth (Bryceson \& Vuorela, 2002; Fresnoza-Flot, 2009; Parreñas, 2005; Schmalzbauer, 2004). These characteristics affect the way that transnational families and their members operate and can have consequences for both sides of the transnational family. Recently, scholars from family sociology and child psychology have started to investigate the effects of separation on the well-being of children in the country of origin through the use of cross-sectional survey data (Graham \& Jordan, 2011; Jia \& Tian, 2010; Wen \& Lin, 2012). These studies indicate that marital status, parents' socio-economic status, sex of parent and child, caregiver, age at separation and length of separation are important factors that affect the well-being of the children in the country of origin (Mazzucato, 2013a). However, this type of quantitative research is scarce for migrant parents.

To gain a full understanding of how transnational separation is associated with well-being, a comparison group consisting of parents who live with their children in the host country is needed. This makes it possible to determine if associations observed are specific to transnational families or to all migrants (Mazzucato \& Schans, 2011). In this dissertation I make use of cross-sectional survey data that contains both transnational and non-transnational parents. Using these means, I am able to disentangle the effects of transnational family life and other factors to isolate the effect that transnational separation has on parental well-being. In other words, these methods allow me to assess the effects of transnational family life, explore which factors are of main importance and 
study the interplay of these factors with transnational family life while controlling for basic demographic characteristics.

The fourth contribution concerns the comparative nature of this study. Most studies on transnational families are in-depth ethnographic accounts (Banfi \& Boccagni, 2011; Graham \& Yeoh, 2013; Schans, 2009) whose insights are explored further in this thesis. Yet these studies focus on one particular origin group. One way I add to these studies is by conducting a comparison between different migrant groups to explore how macro- and meso-level factors, such as migration policies or the contexts of migration can shape family life across borders. This study focuses on Angolan and Nigerian migrant parents in The Netherlands. Although both are studied in the context of The Netherlands, yet they differ in their migration trajectory to The Netherlands. Angolans came mainly as asylum seekers and Nigerians through family reunification and labour migration, resulting in different settlement patterns in The Netherlands. For example, while many Angolans have obtained Dutch citizenship, a substantial number of Nigerians are undocumented. This comparison thus enables the study of whether migration policies and structural factors affect transnational family life and establishes whether patterns can be found across migrant groups.

The geographical focus on these two sub-Saharan African groups forms the last contribution. There has only been limited research on recent immigrant groups in The Netherlands, especially on immigrants from sub-Saharan Africa, despite the fact that these migrants have been growing in number in recent years (Grillo \& Mazzucato, 2008; Koser, 2003). This is an important gap in the literature because these migrant groups face a very different migration and receiving context than the old migrant groups, such as the Turks, the Moroccans, the Surinamese and the Antilleans, who are studied extensively in Dutch migration research. Additionally, in the transnational family literature, there has been a limited focus on the sub-Saharan African context. The overall majority of studies focused on families from Latin America, Asia and, more recently, Eastern Europe. Transnational family life and the effect this has on parents and children might be different in the Sub-Saharan African context because unlike many regions where transnational family studies have been conducted, child fosterage is a common practice in certain parts of sub-Saharan Africa (Howell, 2009; McDaniel \& Zulu, 1996; Whitehouse, 2009). As a result these migrant parents and their children might not experience the same emotional distance and dislocation that are described in the other transnational contexts (Mazzucato \& Schans, 2011; Whitehouse, 2009). In Angola and Nigeria, the countries where the migrant parents under study originate, child fosterage is also commonplace (Isiugo-Abanihe, 1985; McDaniel \& Zulu, 1996; Øien, 2006). In addition, the data from the TCRAf-Eu project, which is used in this dissertation, indicate that the amount of transnational families in urban, high-out migration areas surveyed in these countries is significant. Out of approximately 1,600 school children 
surveyed in these areas, 2.6 percent were living in a transnational family in Angola and 3.5 percent in Nigeria (Mazzucato et al., 2013).

This dissertation is part of a larger project, named Transnational Child Raising Arrangements between African and Europe (TCRAf-Eu ${ }^{1}$ ), which investigates how transnational child raising arrangements affect the well-being of the different actors in transnational families, namely, the children who remain in the country of origin, their migrant parents and their caregivers in the origin country (Mazzucato, 2009b). To make cross-country comparisons possible, the TCRAf-Eu project has studied three African sending countries and three European receiving countries using 5 migratory flows: Angola - Portugal; Angola - The Netherlands; Nigeria - Ireland; Nigeria - The Netherlands, and Ghana - The Netherlands. In addition, to enhance our understanding of transnational child raising arrangements, an interdisciplinary and mixed-methods approach, which includes quantitative data analysis of both children and parents, ethnographic fieldwork in all locations, a transnational matched-sample methodology and an institutional analysis, is used. With this dissertation I have investigated one of the research questions that the TCRAf-Eu aims to answer, namely, the effect that transnational child raising arrangements have on the well-being of Angolan and Nigerian migrant parents in The Netherlands.

In the remainder of this chapter, I will further develop the theoretical framework of this dissertation. I will place this study in the context of the broader literature of migration studies and transnationalism studies and will situate this study in the transnational family literature. Lastly, the empirical chapters in which I examine the effects of transnational parenting are introduced.

\subsection{Migration \& Transnationalism studies}

For a long time, studies in the migration literature were predominantly focussed on assimilation and integration of migrants in the host countries, assuming that eventually, the well integrated migrants would lose touch with home (Guarnizo, Portes, \& Haller, 2003; Levitt \& Jaworsky, 2007). Only in the last three decades increasing attention has been paid to cross-border networks that are important to migration and other more intricate and differentiated movements. Initially, the focus was on diaspora, maintaining longstanding networks between several host countries and a homeland. Yet, this approach did not incorporate the large group of migrants who regularly crossed borders and stayed in constant contact with their families and friends back home (Kofman, 2004). In the early 1990s transnationalism arose as a new concept to counter earlier views of migration as a one-way process and to incorporate the fact that international

\footnotetext{
${ }^{1}$ For more information on the project, refer to www.tcra.nl
} 
migrants maintained strong ties to the home society in an increasingly globalised world (Mazzucato, van Dijk, Horst \& de Vries, 2004).

Basch, Glick Schiller, and Szanton-Blanc (1994) were among the first to theorise transnationalism and defined transnationalism as "the process by which immigrants forge and sustain multi-stranded social relations that link together their societies of origin and settlement" (p.6). Other important scholars in the field of transnationalism, Portes, Guarnizo, and Landolt (1999, p. 219), emphasise that there are certain conditions for transnationalism: it has to include a "significant proportion of persons", and transnational activities should "possess certain stability and resilience over time". Put simply, transnationalism concerns the various but continuous and regular activities that link immigrants in their current place of residence to communities in the place of origin, but it can also include networks that link migrants in different locations other than the country of origin. These economic, political social and cultural linkages or activities produce flows of people, money, and knowledge that affect both the home and host societies (Al-Ali, Black, \& Koser, 2001; Mazzucato et al., 2004; Portes et al., 1999).

Although transnational practices cannot be regarded as new, recent developments in communications and travel have certainly altered the phenomena (Basch et al., 1994; Portes et al., 1999). For example, it has become much easier to electronically send money home or to stay in contact with family members back home through travel, phone or internet. While different definitions of transnationalism emerged and the concept has been criticised for being too broad (Levitt \& Waters, 2002), the strength of transnationalism resides in the fact that it includes processes that extend beyond the boundaries of the nation-state, thereby taking multiple countries and their peoples into account. This is especially important for the study of transnational families. Our understanding of migrants' lives and well-being in the host country will be much enhanced when we take a transnational perspective, taking the relationships that migrants maintain with people and institutions in the home country into account (Glick Schiller, Basch, \& Szanton-Blanc, 1992) because the two might be very well related. As transnational family studies indicate, events that happen thousands of miles away, such as the sickness of a child in the country of origin or the death of a family member, can affect the well-being of migrant parents in the host country. More importantly, a lesson to be drawn from transnational studies is that migrants, although to various degrees, maintain transnational networks or linkages, and these are inherent in their lives.

A transnational approach is especially important in the study of families. But although transnational families have existed across the world for centuries, they have rarely been the subject of study until the late 1990s (with some clear exceptions, e.g., Nakano Glenn, 1983; Thomas \& Znaniecki, 1927; Watson, 1977). For a long time, transnational family ties have been neglected by family sociologists and psychologists and migration and transnationalism scholars alike (Mazzucato \& Schans, 2011). There is a long tradition of migration scholars ignoring the importance of the family in migra- 
tion (Kofman, 2004; Kraler et al., 2011; Zlotnik, 1995). As Zlotnik (1995) and Kofman (2004) argue economic theory has long been influential in migration studies resulting in an emphasis on economic activities and a view of migration that is driven solely by economic reasons that move beyond the family. Because families in themselves do not generate income and are located in the social and reproductive spheres these scholars largely overlooked them. Additionally, migration scholars predominantly used the individual as the unit of analysis and consequently disregarded the families of which they were part (Kraler et al., 2011).

Furthermore, when the family was taken into consideration in migration research, studies were mostly focused on the nuclear family or the household, thereby ignoring other family constellations, such as transnational families in which childcare is provided by the others in the country of origin (Bryceson \& Vuorela, 2002; Mazzucato, 2013b). That is because in the West the terms family household, i.e., "the management and sharing of everyday life in a common dwelling" (Bryceson \& Vuorela, 2002, p. 28), are often used interchangeably. As a result, questions in migrant surveys and social policies were aimed at people living in the household and did not take transnational ties into account. However, research that is explicitly focused on the family, such as in the fields of family sociology and psychology, for a long time was predominantly focused on the white middle-class nuclear family. This scholarship failed to recognise the diversity of parenting practices in the past. Yet, even though this scholarship increasingly acknowledges the plurality of parenting practices, such as adoption or same-sex parenting, it still emphasises physical proximity as a precondition for interaction within families and thereby ignores family ties that cross borders and hence the challenges these parents face (Baldassar \& Baldock, 1999; Madianou \& Miller, 2012; Schans, 2009; Zontini, 2004).

In sum, migration and family studies have ignored transnational families for a long time because they were too focused on questions of integration and assimilation and took the ambiguous concept of the co-present family or household as the point of departure. The concept of transnationalism enables one to look beyond the nation-state and study transnational ties and hence the family life that crosses borders. While there have been many studies on globalisation and migrant transnationalism since the 1990s, they have traditionally focused on political or economic activities that cross borders. As a result, until recently relatively few transnational migration studies have also focused on transnational family separation, despite the fact that transnational family members are very important actors in these transnational activities (Madianou \& Miller, 2012; Schans, 2009; Whitehouse, 2009). Only since the early 2000s has more attention been paid to transnational families in this scholarship. In the next section I will discuss this scholarship and present the main findings of transnational family studies. 


\subsection{Transnational families}

\subsubsection{The emergence of transnational family studies}

Historically, it was mostly men who migrated abroad. They would gradually bring over the dependent wife and children or would return to the country of origin after economic returns were made (Dreby, 2006; Hondagneu-Sotelo \& Avila, 1997; Kraler et al., 2011). At the time, these families received little scholarly attention because this type of migration was seen as temporary and father-child separation was not regarded as an abrupt break in family life; hence, the negative consequences for the child were seen as minimal (Parreñas, 2008) Some of the first scholars to take transnational families as the subject of study were feminist scholars because they noted that mothers progressively migrated while leaving their children in the country of origin. While in the past it was mostly men who settled abroad leaving behind their families, the feminist studies (e.g. Hochschild, 2000; Hondagneu-Sotelo \& Avila, 1997; Parreñas, 2000, 2001) showed that the global division of labour and global inequality demanded female workers from the Global South to work in the Global North. Women of the Global North were increasingly entering the workforce, and as a result the women of the Global South were needed to take over their reproductive tasks. These conditions created the so-called 'care-chain' or 'care-drain', in which deprived women of the South left their children in the care of others to perform care tasks in the Global North. Central to these studies was the political economy of care, the difficulties these mothers experienced with conforming to gender ideologies and the difficulties in providing for their family back home both financially and emotionally. These studies showed the hardship and emotional suffering these mothers faced in the host country, which were to some extent the result of these mothers' inability to live up to the ideological views on the roles of mothers in both their home and host communities.

The global feminist discourse and care-chains approach were predominantly focussed on the negative effects of globalising forces, such as the inequalities in the current political economy in which migrants had to pay high social costs to reap economic gains for their families. Also, transnational family life was regarded as an infringement of the norms of biological motherhood and co-present parenting (Madianou \& Miller, 2012). At the end of the 2000s and beginning of the 2010s, this scholarship was criticised for its bias towards the nuclear family model in which biological parents and children reside together. It ignored the fact that co-present parenting is not a global norm and that extended families have played a key role in caregiving in various communities across the world for centuries (Madianou \& Miller, 2012; Mazzucato, 2013b). Additionally, because the global feminist discourse was so focussed on how the political economy was unjust towards these mothers, it overlooked the agency and empowerment of these mothers in migration (Bernhard et al., 2009; Madianou \& Miller, 2012). 
Finally, this body of literature was criticised for disregarding migrant fathers within transnational families (Dreby, 2006; Pribilsky, 2004; Waters, 2009).

More recently, transnational family studies have moved away from this feminist discourse and have broadened the scope of research, leading to a burgeoning literature on transnational family life. First, ethnographic studies have studied the emotional difficulties that various actors in transnational families experience as a result of separation, how these actors maintain relationships across borders, and how transnational parenting is practiced. They have studied the experiences of transnational mothers, children 'left-behind', transnational fathers and caregivers, although the latter two remain understudied. Anthropological research has also been performed on the difficulties that arise when parents and children reunify. Studies in qualitative sociology, furthermore, point to the inequalities and diversity that exist within transnational families and to the economic, social and political factors that affect the existence and functioning of these transnational child-raising arrangements. More recently, quantitative sociological and psychological studies have been conducted on the effects that transnational separation has on the behaviour, academic performance and psychological well-being of children 'left behind'. Finally, legal studies have investigated the legal obstacles to reunification that these families face. I will summarise the most important findings of this research in the next sections.

\subsubsection{Causes for transnational family separation}

The decision to migrate while leaving children in the country of origin is dependent on several factors in both the country of origin and the destination, such as the economic situation before migration, the expected economic merits in the country of destination, social capital and human resources in both countries, migration policies and migration status (Bernardi, 2011; Bryceson \& Vuorela, 2002; Carling et al., 2012; Parreñas, 2005; Schmalzbauer, 2004). These factors not only determine whether to leave one's children in the care of others in the country of origin but also determine if and when parents and children who are separated can be reunited. Moreover, other factors, such as sex, age, legal status, and socio-economic status, mediate the ability to provide transnational care (Evergeti \& Ryan, 2011). Although these factors are highly important, they have often been overlooked by transnational family studies (Carling et al., 2012). Thus, transnational families develop in various conditions, and the spatial separation of parents and children can have various causes, some of which will be discussed below.

The economic status of the family before migration strongly influences decisions regarding migration and family separation (Schmalzbauer, 2004). First, migration is a risky and costly endeavour that requires cash for travel to and accommodations within the host country. That is why oftentimes one member of the family migrates first with the intention of bringing the rest of the family over once he or she settled in the host country and enough economic returns have been made to pay for the arrival of other 
family members. Second, some families feel they have no choice but to live across borders and send one or more family members overseas for labour, ensuring enough income to escape poverty. These parents want to make use of the cross-border division of labour in which reproduction costs are lower in the country of origin and production reaps higher benefits in the host country (Bernardi, 2011; Coe, 2008).

The development and maintenance of transnational families can also be the result of stringent migration policies that restrict spatial mobility and choices of action. The stricter border controls make it difficult to impossible to bring family members over, prevent migrants and their families from going back and forth, and consequently affect the amount of physical contact they can have (Carling et al., 2012; Fresnoza-Flot, 2009; Horton, 2009). These strict migration policies have also made family reunification difficult. For undocumented parents, crossings borders has become very dangerous, and consequently neither can they travel home to visit their children nor can their children visit them. This situation results in prolonged separations and emotional hardship that affects their caregiving practices.

Research has also shown the importance of social networks. Social networks in both the country of origin and destination are crucial in deciding who migrates because these networks provide the information that is necessary to make this decision but are also important for arranging childcare (Bernardi, 2011; Salaff \& Greve, 2004). According to Bryceson and Vuorela (2002), moving with the whole nuclear family, i.e., parents and children of school age, is unlikely unless childcare and schooling in the host country have been seriously considered and arranged. Turkish mothers in Germany interviewed by Erel (2002), for example, stated that the availability of affordable childcare and the reliability of the caregivers were critical in deciding whether to bring the children along to the host country. Generally, it was preferable to leave the children in the care of a trusted relative as opposed to taking them to Germany where they would be placed in the care of strangers. When family members who can help with childcare already reside in the host country, one is more likely to take one's children than if there were no one to help with taking care of the children and there were no means to arrange for professional childcare. Thus, class and social networks are likely to influence the decision to leave children behind. Yet, not only is the situation in the host country important but the networks of care that are available in the home country are also crucial. Generally, parents only want to leave their children behind if they know that they will be well taken care of in their absence.

In addition, the political and economic situation of the home country is vital, e.g. one is less likely to leave one's children behind in a country of civil unrest (Carling et al., 2012). However, violent conflict and war can lead to dislocated family bonds and care networks and to break up families (Nzatuzola, 2006). The recent upsurge of child migration from Honduras, Guatemala and El Salvador to the U.S. and the Syrian refugee crisis are just two examples. Not only can these conflicts be a cause of separation, but 
they often also result in trauma that can intensify the negative effects that transnational separation has on both parents and children (Suarez-Orozco et al., 2002). Leaving a child in an unsafe conflict or post-conflict setting can also lead to extra stress and worry. Hence, the impact that transnational separation has on the lives of refugees and their children might be very different from the impact that transnational separation has on the lives of economic migrants. Yet, little is known about the effects of war on this type of transnational family because most transnational family studies focused on labour migrants (Rask, Warsame, \& Borell, 2014).

Other reasons for transnational family life can be that parents prefer their child to grow up in the presence of the extended family and in the safe cultural environment of the home country (Aranda, 2003; Whitehouse, 2009). Separations can also be the result of the preference of the educational system of the home country (Coe, 2008; Nobles, 2011). Finally, broken relationships can trigger migration decisions and lead to transnational family life (Hill, 2004) but also affect the functioning of transnational child raising arrangements and family life in general (Amato, 2000; Amato \& Booth, 1996; Nobles, 2011).

These various separations can last for a short or long period of time. Some parents delay bringing their children to the host country because they first want to settle down, do not have the right documents or enough resources or want to reunite in the country of origin. Additionally, sometimes children do not want to reunite with their parents in the host country. Having established possible reasons for transnational family life, I will discuss how parenting across borders is found to affect transnational parents.

\subsubsection{Parenting across borders and its consequences}

Transnational scholarship has consistently shown that transnational child raising arrangements can affect both the parent in the host country and the child in the country of origin. Here, I will discuss the main findings on the effects that transnational parentchild separation has on migrant parents.

The main emphasis in transnational family studies has been the emotional suffering of transnational parents, especially mothers. Despite the efforts by parents, it is common for lengthy separations, infrequent and limited physical contact over the years and limited communication to lead to estrangement and consequently limited emotional well-being (Banfi \& Boccagni, 2011; Bernhard et al., 2009; Fresnoza-Flot, 2009; Horton, 2009; Parreñas, 2001, 2005; Schmalzbauer, 2004). Transnational parents struggle with the fact they miss a great deal of the childhood of their children, a feeling that becomes apparent at major life events, such as birthdays or graduations. Separation is especially difficult when something happens to the child, such as sickness, resulting in emotional distress and feelings of helplessness. Additionally, over time parents often lose their parental authority, which is difficult to maintain without physical contact (Boccagni, 
2012). This realisation also causes emotional hardship and frustration, as authority is at the heart of parenting.

Mothers especially have been found to suffer emotionally. One of the reasons transnational mothers are especially reported to feel guilty, embarrassed, ashamed, and hopeless is that transnational mothering deviates from the norms of co-present parenting. Despite the fact that material gains can soften the effects of separation, these mothers feel that they are unable to realise their mothering responsibilities and can become depressed as a result, especially when their environment and public discourse criticise these mothers for 'abandoning' their children (Bernhard et al., 2009; Boccagni, 2012).

Finally, the relationships that migrant parents, caregivers and children are able to maintain have been found to be very important for the well-being of both parent and child (Boccagni, 2012; Carling et al., 2012; Parreñas, 2005). Transnational parents work hard to maintain intimate relationships with their children in the country of origin. They make regular phone calls, write letters, send gifts, and visit when possible. Yet, despite these efforts, most studies indicate that transnational family life challenges the maintenance of good and intimate parent-child relationships because geographical separation constrains emotional involvement.

Communication is key to the maintenance of good relationships with children and caregivers back home and can reduce the emotional costs of separation (Boccagni, 2012; Carling et al., 2012; Fresnoza-Flot, 2009; Horton, 2009; Madianou \& Miller, 2011; Parreñas, 2005; Zentgraf \& Chinchilla, 2012). Communication allows parents to be concomitantly present in the host and origin country and allows children and parents to engage with each other's lives. In doing so, parents reconstitute their parental role, confirm the emotional and parental relationship they have and thereby ameliorate the negative effects of their absence. In other words, while the parent is physically absent, contact enables the parent to be psychologically present and can as such reinforce family ties (Madianou \& Miller, 2011; Parreñas, 2005; Zentgraf \& Chinchilla, 2012). Additionally, contact allows for a sense of coherence, which can help reduce the emotional pain and guilt that parents feel.

New communication technologies enable transnational family members to communicate more regularly and with different means (Dreby \& Adkins, 2010). This is important because studies show that regular and high quality-communication is imperative because it serves as a continuous verification of the parent-child relationship (Carling et al., 2012). Hence, although findings show that it cannot be a substitute for physical contact, regular communication is central to parenting across borders. Remittances are a form of maintaining contact and therefore are also of vital importance to maintaining good relationships (Parreñas, 2005; Zentgraf \& Chinchilla, 2012). The ability to send remittances is one of the reasons some migrants migrated in the first place. Therefore, parents hope that the remittances they send lessen the emotional costs of their migration and provide their children with better opportunities. 
Separation is a cause for emotional hardship and affects parent-child relationships in most cases. However, the effects of separation are also dependent on various conditions, such as socio-economic and legal status. Socio-economic status and legal status can affect how migrant parents practice parenting across borders because the provision of care is dependent on access to financial and legal resources (Bernhard et al., 2009; Evergeti \& Zontini, 2006). One needs enough economic resources to keep in touch and stay connected with family back home. Although new communication technologies such as the internet have made it easier to maintain contact with family members and trips back home have been made possible by cheaper and more frequent flights (Schmalzbauer, 2004), not everyone has the means to make use of these technologies regularly. Furthermore, when parents do not succeed in sending remittances frequently, relationships can be strained (Carling et al., 2012; Dreby \& Adkins, 2010). For example, Dreby and Adkins (2010) have documented in their study amongst Mexican migrant parents in the US that, when poor migrant fathers can no longer send money back home, they may terminate contact with their families in the country of origin because they cannot provide for them anymore. Undocumented status leads to protracted separations and intensifies emotional suffering because it prohibits regular visits, which are found to be essential in the maintenance of good parent-child relationships (Fresnoza-Flot, 2009; Horton, 2009). In addition, undocumented status is often tied to low socio-economic status and irregular income, which as shown above can impact the parent-child relationship.

The extent to which transnational separation is in tension with gender and parenting norms also differs from region to region. A large share of the transnational family studies ascribe part of the difficulties transnational mothers experience with separation and the tensions in family relations this results in to these mothers' inability to live up to traditional gender and family norms. However, childrearing is not limited to biological parents alone, and co-present parenting is not a worldwide norm (Coe, 2008; Madianou \& Miller, 2012; Mazzucato, 2013b). Many migrants in today's Global North come from societies in which the extended family plays an important part in the upbringing of children and it is not uncommon for children to be raised by people other than their biological parents. Children are regarded as belonging to the whole lineage or kinship group and not solely to the biological parents (Isiugo-Abanihe, 1985; Monaghan \& Just, 2000). The practice of social instead of biological parenting is exemplified by the practice of child fosterage ${ }^{2}$, an ancient and deeply embedded practice in various cultures of sub-Saharan Africa, Latin America, Asia and the Pacific (Mazzucato, 2013b). Child fosterage remains commonplace in sub-Saharan Africa (Alber, 2003; Zimmerman, 2003), including in the countries under study, Angola and Nigeria (McDaniel \& Zulu, 1996; Øien, 2006).

\footnotetext{
2 "The relocation or transfer of children from biological or natal homes to other homes where they are raised and cared for by foster parents" (Isiugo-Abanihe, 1985, p. 53).
} 
It would seem that, in contexts in which child fosterage is commonplace, migrants and their children may not experience the same lack of intimacy and sense of dislocation that the parents and children who have been studied in a context in which the nuclear family system is the norm may experience (Whitehouse, 2009). In these communities, transnational family arrangements represent less of a break from norms around child rearing than in communities where co-present parenting is the norm. Therefore, the effects of separation on parents and children might also be different in these communities. However, migration to another continent and the transnational child raising arrangements that follow may be different from the child fostering arrangements described above. First, the geographical distance could make it more difficult to maintain the same relationship with the caregiver. In addition, although child fosterage may be commonplace, the emotional costs involved in parent-child separation should not be downplayed regardless of the norm, especially because child-parent separation has occasionally proven to be problematic in the sub-Saharan African context (Goody, 1982).

\subsubsection{Contribution to transnational family studies}

What this overview has showed us is that transnational families do not exist in a vacuum. They are affected by geographical, social and economic inequalities, access to communication and travel, the need of labour, migration laws and care networks. Although the above cited studies list a wide range of factors that are important for the existence and functioning of transnational families and have revealed the importance of these factors in their studies, they have often only focussed on one or a few of these factors. Seldom have these factors been studied simultaneously. The quantitative nature of this dissertation enables the exploration of multiple factors simultaneously as well as the investigation of how these factors mediate or moderate the associations found. In addition to factors on the individual level, this dissertation explores contextual-level factors. The comparison of two migrant groups that came to The Netherlands under different circumstances allows the study of whether conditions in which parents leave the home country, e.g., a post-conflict setting, have an impact on how transnational family life is experienced. Given that cross-sectional data are used, causality cannot be determined, but, to isolate the effect of transnational separation, a comparison group that consists of Angolan and Nigerian migrant parents who live with their children in The Netherlands is used.

Furthermore, few scholars have compared the experiences of transnational mothers and fathers (Carling et al., 2012). Most of the studies noted above have transnational mothers as their main focus and claim that separation is especially difficult for them because of existing parenting norms that dictate that mothers are the prime caretakers and are expected to perform emotional care. Fathers, however, are expected to provide financial care, which is easier to provide across borders (Dreby, 2006; Parreñas, 2005). 
Yet, this does not mean that fathers are not also affected by transnational separation, although we know little of the effects that transnational separation has on them because fathers have been under-researched (Poeze \& Mazzucato, 2012; Pribilsky, 2004; Waters, 2009). The data this dissertation makes use of contain both transnational fathers and mothers and allow for a comparison of effects through statistical analyses. In other words, I can explore whether transnational separation results in worse emotional outcomes for transnational mothers in comparison to transnational fathers, as some of the literature seems to suggest.

Finally, as noted at the beginning of this chapter I will connect different disciplines in the study of the effects of transnational family life. Linking transnational family studies with research on migrant well-being and work-family balance enables an enhanced understanding of transnational parents' lives, which are affected by a multitude of factors. The migrant well-being literature has indicated that certain migrant groups with high unemployment rates, small social networks, low socio-economic status and undocumented status are particularly vulnerable to low psychological and physical wellbeing, which indicates that we should not study transnational family life in isolation but in parallel with other factors known to affect well-being. By taking these other factors into account, we are able to isolate the effect that transnational family separation has and understand whether the low parental well-being observed is linked to these other factors of importance or is indeed the result of transnational family life.

Drawing from other disciplines can also focus our attention to aspects of well-being not explored before. Linking transnational family studies to organisational psychology leads us to believe that transnational parenting can be associated with job outcomes in multiple ways. It can either lead to favourable job outcomes through reduced workfamily conflict or unfavourable job outcomes through the low subjective well-being reported by transnational family studies. Yet, despite the fact that work is essential for transnational parents because it enables regular remittances and hence is important for transnational parent-child relations, the job outcomes of transnational parents are under-researched. This dissertation will explore in what ways transnational parenting is associated with particular job outcomes.

\subsection{Overview of the dissertation}

As noted above, this dissertation investigates the association between transnational family life and the well-being of Angolan and Nigerian migrant parents. It does so in three areas: transnational parent-child separation, subjective well-being, and jobperformance. The empirical part of this dissertation consists of three chapters that are stand-alone articles; some of which have been published and others have been submitted to international and refereed journals. Some minor changes have been made to these empirical chapters to fit this dissertation: the different sections have been renumbered, 
reference lists have been moved to the end of the dissertation for readers' convenience, referencing styles have been adapted, and the formatting of the tables has slightly changed. The last empirical chapter, Chapter 6, has seen the biggest changes because the paper submitted for publication is only focussed on Angolan parents; the Nigerian sample is only used in the chapter part of this dissertation. The concluding chapter will bring the findings of these separate chapters together and provide suggestions for further research.

Chapter 2 is a background chapter that discusses how Angolans and Nigerians have entered The Netherlands, how they have been received by Dutch society and presents some socio-demographic and socio-economic characteristics of these groups. As such, it helps to understand some of the sample characteristics that will be presented in Chapter 3 and helps to understand which factors are important to take into account when studying these groups. The chapter starts by providing a short overview of Dutch migration history, followed by a short account of Angolan and Nigerian migration to The Netherlands. Second, it summarises the migration policies of significance for the parents under study, after which secondary data on Angolans and Nigerians in The Netherlands is provided. As such, this chapter explores the context in which the transnational families under study came into being and currently operate.

Chapter 3 is a data and methodology chapter. It starts with a detailed account of the collection of data used throughout the dissertation, the sample characteristics and a short reflection on the methods used throughout the dissertation. Henceforth, this chapter discusses the distinguishing features of the data on the transnational parents by comparing them to non-transnational parents. Additionally, taken into special consideration are the differences between Angolans and Nigerians that these descriptive statistics bring to the fore. In sum, this chapter provides a description of the data and methods used and a first account of the transnational families who are part of this dissertation. It should be seen as a building block for the empirical chapters.

Chapter 4 is the first of three chapters to study consequences of transnational family life on the lives of transnational parents. As explained above, previous studies indicate that transnational family life can challenge the relationships between migrant parents and children in the country of origin. We have already learned from the short overview of transnational family studies presented above that transnational families are not uniform and function differently according to their specific characteristics. Therefore, in this chapter I aim to investigate how different factors are associated with the quality of parent-child relationships in transnational families. Based on an extensive literature review, five factors are found to be of special importance: the gender of the migrant parent; contact and remittances; the characteristics of the caregiver; the length of separation; and the age of the child and age at separation. These factors have not been studied simultaneously, and there is no quantitative evidence of the relationship between these factors and how parents assess the relationship with their child in the origin 
country. Chapter 4 thus asks which conditions are important for the maintenance of good parent-child relationships across borders.

In Chapter 5 the effect of transnational parent-child separation on the subjective well-being of Angolan and Nigerian transnational parents is investigated. This chapter aims at reviewing and synthesising two areas of research to study the subjective wellbeing of transnational parents: transnational family studies and the migrant well-being literature. The latter has a long history of studying migrant well-being; however, it is predominantly focused on nuclear co-resident families or families in which parents are divorced. By and large, transnational families have been overlooked by this body of literature. On the other hand, as noted above, most transnational family studies point to the emotional consequences of parent-child separation. Again, most studies have employed qualitative methods to study subjective well-being without comparing it to the well-being of non-transnational parents. This makes it difficult to distinguish whether effects found are associated with separation only or with other factors. This chapter investigates the association between parental subjective well-being and parentchild separation by comparing migrant parents who have at least one child in the country of origin with those who live with all their children in The Netherlands. Chapter 5 thus raises the question whether transnational parents report lower subjective wellbeing and whether this can be attributed to the parent-child separation.

While Chapter 5 investigates emotional well-being, an aspect of transnational parents' lives previously investigated by transnational family scholars, Chapter 6 breaks new ground, namely, the job outcomes of transnational parents. This final empirical chapter starts with a review of two bodies of literature: work-family conflict and the happy productive worker thesis, resulting in two opposing hypotheses regarding the association between transnational family life and job performance. On the one hand, the work-family conflict literature suggests that transnational parenting might lead to less work-family conflict, which has been found to lead to better job performance. On the other hand, the happy productive worker thesis established an association between happiness and enhanced job performance. As transnational parents have been found to suffer emotionally because of the separation, we can therefore hypothesise that they would display lower job performance than non-transnational parents. Thus, Chapter 6 addresses the question whether transnational parents perform better or worse than their non-transnational counterparts and whether this is mediated by happiness or workfamily conflict.

This dissertation will conclude by synthesising the findings of the empirical chapters and will summarise the main contributions to the transnational family literature. In doing so, it will distinguish the main factors of importance to the well-being of transnational parents. This dissertation ends with some suggestions for future research and policy. 

CHAPTER 2.

Angolans and Nigerians in The Netherlands 



\subsection{Introduction}

To understand how the Angolan and Nigerian transnational families I study come into being and subsequently operate, I first must explore the contexts in which transnational child raising arrangements originate and function. Uncovering the context of these families' particular arrangements, along with the differences among them, sheds light on which particularities are important to consider when investigating them. The context in which Angolans form transnational families is particularly interesting because it involves war and/or post-war situations in which transnational families have not been studied often (Rask et al., 2014). This war and post-war context may lead to different dynamics in the formation and functioning of transnational child raising arrangements.

It is not only the context of departure that is of importance but also the context in which Angolan and Nigerian migrants are received and in which transnational parents operate. This context is formed by the specific migration trajectory of these migrants to The Netherlands and the specific policies that apply to these groups. In contrast to Nigerians who arrived primarily through family and other forms of migration many Angolans came to The Netherlands through the Dutch asylum procedure after fleeing the war in Angola. In 2001, Angolans were the largest group of asylum seekers in The Netherlands, and a large proportion of them arrived as unaccompanied minors (Wijk van, 2007). The specific asylum policies that applied to Angolans have resulted them holding a very different status in Dutch society than do Nigerians. For example, because many Angolans came as unaccompanied minors, they received a Dutch education and learned to speak Dutch. A significant proportion has been able to obtain Dutch citizenship. Conversely, a large proportion of the Nigerian population is undocumented, a large proportion has low Dutch language proficiency and while Nigerians are often highly educated do not have their qualifications recognized. These differences form the context in which transnational child raising arrangements take shape and are maintained and thus are important to consider. In this chapter I will sketch a short history of Angolan and Nigerian migration, sum up some important migration laws for the families I study and finally present some demographic characteristics of Angolans and Nigerians in The Netherlands.

\subsection{A short history of migration to The Netherlands}

After the end of World War II, the first flow of non-Western migration to The Netherlands was primarily a result of the decolonization of some of the country's colonies. This wave of immigration can be divided in two main flows. First, between 1945 and 1960, approximately 30,000 inhabitants from the former Dutch East Indies migrated to The Netherlands; these migrants were often called 'repatriates'. Second, after 1965 migrants from Suriname and the Dutch Antilles, former Dutch colonies, migrated to The Nether- 
lands, which resulted in 160,000 Surinamese residing in The Netherlands in the late 1970s (Castles \& Miller, 2009). A second large flow of immigrants to The Netherlands resulted from the Dutch guest worker system (i.e., temporary labour recruitment), which operated during the 1960s and early 1970s. As a result of a rapid post-war economic growth, the Dutch government began to recruit migrants from the Mediterranean and Northern Africa, particularly Turkey and Morocco, to replace local workers in low-skilled jobs. Although the system intended that these guest workers would return to their home countries, return rates were low. Many brought over their families and stayed permanently (Castles, 1986; Muus, 2001).

The migration of Angolans and Nigerians to The Netherlands is a relatively recent phenomenon, and both groups can be seen as part of the 'new' immigrant groups arriving from sub-Saharan Africa, only some of whom came as asylum seekers or refugees. Sub-Saharan African migrants to The Netherlands originated mostly in Somalia, the Cape Verde, Ghana, Angola, Ethiopia/ Eritrea, Congo, Nigeria and Sudan (Heelsum, 2005). Despite the fact that sub-Saharan Africans are one of the largest 'new' immigrant groups in The Netherlands, migration from sub-Saharan Africa to The Netherlands has remained under-researched, particularly with respect to the issue of kinship systems under conditions of transnational migration (Grillo \& Mazzucato, 2008; Wijk van, 2007). These groups differ from the 'old' migrant groups in The Netherlands in terms of the dynamics and contextual factors that shape their migration. First, unlike the guest workers, many of these 'new' migrants were not given official status when they arrived in The Netherlands and thus did not become part of the state system upon arrival. Second, the 'new' migrants are relatively young compared to the 'old' migrants, whose third generation is now of school age (Heelsum, 2005; Mazzucato, 2008). Finally, the political climate in The Netherlands has changed drastically over the decades. The Dutch government and population are less welcoming to non-Western migrants than they were in the 1960s and 1970s (Mazzucato, 2008), which has resulted in e.g. stricter migration policies, as will be shown in the next section.

\subsubsection{Angolan migration}

Migration from Angola to The Netherlands is fairly recent and is primarily the result of the war that raged in Angola from its 1975 independence from Portugal until 2002. In particular from 1998 on, extreme fighting resulted in a large number of Angolan Internally Displaced Persons (IDP). For example, in 2002 there were 4 million IDPs out of a population of 13 million (Wijk van, 2008). Many Angolan refugees fled to neighbouring countries, but a large group sought asylum in Europe. In Europe, The Netherlands became a major destination for Angolan asylum seekers (UNHCR, 2002), as displayed in Figure 2.1. Consequently, migration to The Netherlands quadrupled from 3,352 in 1998 to 12,281 in 2004 (Central Bureau for Statistics, 2013) (see Figure 2.2). Angolan migrants to The Netherlands came primarily from middle-class families; their prime 
reasons for migrating were the fear of being forced to fight in the army, the shortage of study and work opportunities in Angola and poverty (Wijk van, 2008). More specifically, in 2000 Angola had a Human Development Index of just 0.384 (indicating low human development), 46 per percent of urban residents were unemployed (Ammassari, 2005), and 61 percent of Angolans were living below the poverty line (Simon, 2001).

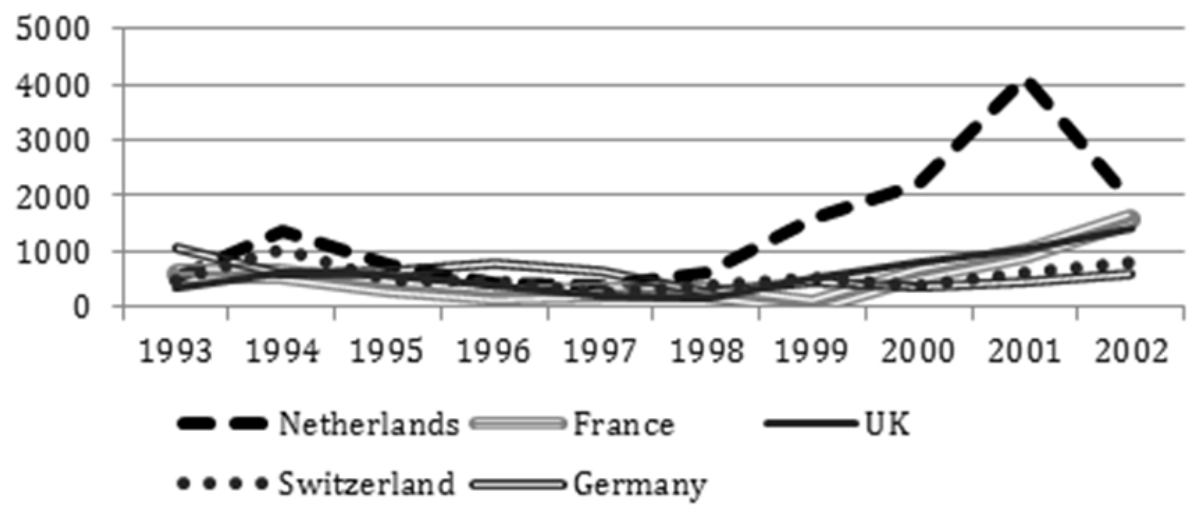

Figure 2.1. Angolan asylum applicants per year in Europe's main destination countries Source: UNHCR (2002).

According to van Wijk (2007), the reason that The Netherlands - which has no colonial or linguistic ties to Angola - became a major European destination was primarily word of mouth. Angolans who had already found their way to The Netherlands told acquaintances and family members that asylum policies were favourable, e.g. they were not easily rejected and they had the opportunity to study in The Netherlands, and that life there was good. Moreover, it was relatively easy for Angolans to apply for asylum in The Netherlands during the war, especially as unaccompanied asylum-seeking minors (UAMs). Consequently, approximately half of the Angolan migrants in The Netherlands came as UAMs (Wijk van, 2007), resulting in a relatively young Angolan migrant population. The official ways in which Angolans entered The Netherlands are recorded in Table 2.1. From 1998 through 2001, the Dutch government did not deport any Angolan asylum seekers because Angola was seen as unsafe, no matter the migration motive. This did not mean they could stay permanently in The Netherlands; however, they did not have to leave the country for a certain period of time. Although all Angolans could stay for that period, there was a big difference in their reception by the Dutch government. Unlike UAMs, Angolan adults were not allowed to study, were not afforded an opportunity to learn the Dutch language, and were allowed to engage in almost no work. Currently, it is much more difficult to migrate to The Netherlands as an Angolan asylum seeker because Angola is seen as relatively safe. Moreover, many Angolans have returned to Angola, some because the Dutch government forced to return and others 
voluntarily. This has led to a sharp decrease of Angolan residents in The Netherlands. The population statistics of the Central Bureau for Statistics (2013) show that at the 2004 peak in Angolan migration, 12,281 Angolans resided in The Netherlands; in 2013 that number had dropped to 8,575 .

Table 2.1. Migration motives of Angolans in The Netherlands (1995-2009)

\begin{tabular}{lcccccc}
\hline Year & Labour & Asylum & Family & Study & Other & Total \\
\hline 1995 & 22 & 583 & 57 & 3 & 18 & 687 \\
1997 & 24 & 223 & 82 & 3 & 10 & 345 \\
2000 & 59 & 1081 & 91 & 1 & 17 & 19 \\
2003 & 61 & 1021 & 59 & 3 & 2 & 1165 \\
2006 & 26 & 58 & 20 & 1 & 2 & 108 \\
2009 & 17 & 77 & 28 & 1 & 1 & 126 \\
2011 & 11 & 69 & 24 & 0 & 105 \\
\hline
\end{tabular}

Source: Central Bureau of Statistics (2013).

Notes: These numbers reflect migration motives of new Angolans entering The Netherlands in each of the respective years. Because the Dutch municipal governments do not provide information about migration motives, for the years 2003 and before, that information has been derived from the Centraal Register Vreemdelingen (Central Register of Foreigners) of the Ministry of Justice. From 2004 on, statistics from the Dutch Migration Service (IND) are used. Every non-EU citizen migrating to The Netherlands must provide his or her migration motive to the IND before entering The Netherlands. Because these numbers are based on information provided to the IND at the time of entrance to The Netherlands, we must treat them with caution; real motives can be different.

\subsubsection{Nigerian migration}

After Nigeria's 1967-70 civil war, it experienced almost 30 years of dictatorship and during the 1980s, economic deterioration. Democracy was reinstalled in 1999 but civil unrest remained. Since 1999, more than 10,000 people have been killed in violent riots as a result of poverty, great inequality, misrule and conflicts related to ethnic and religious differences (Carling, 2006). The greatest religious divide is between Christians in the South and Muslims in the North. This conflict escalated when the Islamic part of the country installed Sharia law in the early 2000s. After Nigeria gained independence in 1960, large migration flows from Nigeria outside of the African continent began. At first, the emigrants were primarily elites who wanted to obtain an education abroad and return to Nigeria. However, because of political instability and economic downturn in the 1970s and 1980s, emigration increased significantly and included lower-skilled migrants searching for better job opportunities. Emigration has been increasing ever since. Larger flows of migration to Europe began in the 1980s and 1990s because of the economic downturn, the corrupt and violent military regime, high inequality and increasing poverty, which led many highly educated Nigerians to migrate to the North (Carling, 2006). 
As a result of this different migration context, Nigerian migration to The Netherlands shows different trends than those of Angolans. Similar to the Angolan migration, Nigerian migration to The Netherlands is quite recent. In 1996, there were only 3,136 Nigerians residing in The Netherlands. However, in 2013 there were 11,466 (see Figure 2.2) (Central Bureau for Statistics, 2013). This represents a greater than three-fold increase since 1996, and these numbers do not account for undocumented Nigerians residing in The Netherlands. Moreover, compared to Angolans and other sub-Saharan nationals, Nigerians follow a relatively diversified migration pattern. Nigerians have come to The Netherlands mainly in search of work. However, as a result of stringent entry requirements for work-seeking migrants, such individuals have many other ways of entering The Netherlands, one of the most important of which is family reunification (see Table 2.2). However, a large proportion of Nigerians also overstays tourist visas and thus become undocumented. In addition, an increasing number of Nigerians enter The Netherlands to study.

Table 2.2. Migration motives of Nigerians in The Netherlands (1995-2009)

\begin{tabular}{|c|c|c|c|c|c|c|}
\hline Year & Labour & Asylum & Family & Study & Other & Total \\
\hline 1995 & 22 & 15 & 161 & 7 & 2 & 208 \\
\hline 1997 & 55 & 50 & 351 & 34 & 14 & 507 \\
\hline 2000 & 70 & 91 & 177 & 35 & 18 & 391 \\
\hline 2003 & 97 & 123 & 237 & 38 & 27 & 526 \\
\hline 2006 & 57 & 18 & 226 & 91 & 54 & 460 \\
\hline 2009 & 53 & 131 & 276 & 128 & 83 & 671 \\
\hline 2011 & 53 & 83 & 253 & 159 & 69 & 105 \\
\hline
\end{tabular}

Source: Central Bureau of Statistics.

Notes: These numbers reflect migration motives of new Nigerians entering The Netherlands in each of the respective years, but concerns only Nigerians who are registered at the municipality and hence who obtained a (temporary) residence permit. Asylum seekers register at the municipality only some time after they have applied for asylum, mostly after six months. Because the Dutch municipal governments do not provide information about migration motives, for the years 2003 and before, that information has been derived from the Centraal Register Vreemdelingen (Central Register of Foreigners) of the Ministry of Justice. From 2004 on, statistics from the Dutch Migration Service (IND) are used. Every non-EU citizen migrating to The Netherlands must provide his or her migration motive to the IND before entering The Netherlands. Because these numbers are based on information provided to the IND at the time of entrance to The Netherlands, we must treat them with caution; real motives can be different.

Compared to Angolans and other sub-Saharan African migrants, few Nigerians came to The Netherlands as asylum seekers; however few Nigerian asylum seekers applied for asylum in The Netherlands (Carling, 2006; Heelsum \& Hessels, 2006). The first Nigerian asylum seekers in The Netherlands were reported in 1987, and in 1990, Nigerians formed 5 percent of asylum seekers. The reasons given for applying for asylum from Nigeria are diverse and include political persecution, persecution due to homosexuality, 
and escape from Sharia law (Carling, 2006). Because the political situation in Nigeria remains unstable and changes from year to year, and as a result of changes in Dutch immigration policy, the number of Nigerian asylum seekers in The Netherlands has fluctuated. For example, in 2006 only 18 Nigerian migrants came as asylum seekers, whereas in 2009, the number was 131 (Heelsum \& Hessels, 2006). However, because Nigeria is seen as relatively safe by the Dutch government, most Nigerian asylum seekers are rejected and in recent years, Nigerian asylum seekers have been sent back.

\subsection{Recent developments in immigration law}

The reception of Angolan and Nigerian migrants in The Netherlands is formed by their migration trajectory and the subsequent migration policies that apply to them. Different policies apply to asylum seekers and labour migrants. This section will discuss various policies that are of importance to the groups under study and are important for transnational families. While in general different policies apply to asylum seekers and refugees, some migration laws apply equally to both groups. For example, family reunification conditions apply equally to refugees after three months of arrival as to labour migrants.

\subsubsection{Vreemdelingenwet}

At the end of the 1970s, the Dutch government realised that The Netherlands had become a migration country and that guest workers were not returning to their countries of origin but instead were bringing their families over. As a result, Dutch migration policy placed more emphasis on family migration (Obdeijn \& Schover, 2008). Furthermore, primarily as a result of family reunification amongst the Turkish and Moroccan migrant groups, the number of immigrants in The Netherlands tripled between 1975 and 1985. Consequently, Dutch migration laws became much stricter and migration became a growing political issue. This development is reflected in the 1979 and 1995 changes to laws concerning foreign employees, which became more restrictive, forcing employers to request a special work permit for every employee hired from outside the EU (WODC, 2009). This marks the end of liberal Dutch migration policy, which became one of the most restrictive policies in Europe. Conversely, Dutch policy related to highly skilled migrants became more liberal (ibid.).

Here it is important to note that in 1986, an important amendment was made to Dutch family migration policy. The so-called feitelijke gezinsband (effective family bond) was added to the law, which meant that parents who had been separated from their children for an extended period of time lost their right to family reunification. The effective family bond was considered broken if the child was taken into another household, if the parents did not have custody of the child and if the parent had not always financially supported the child. In practice, demonstrating an effective family bond 
proved hard, especially if family separation lasted for more than two years (Bonjour, 2009; Walsum van, 2003).

At the end of the 1980s, migration became increasingly politicised because ethnic minorities were seen to lag behind the native population in terms of labour market performance and education. Additionally, immigration was seen as a permanent phenomenon. Since the 1990s, labour migration to The Netherlands for non-EU members has become more and more difficult. Some of the few legal ways to enter The Netherlands in the 1990s were family reunification, family formation and asylum (Obdeijn \& Schover, 2008); in recent years, family reunification and formation have become more difficult. The 1990s can, moreover, be characterised by a paradigm shift from a focus on the guest worker or labour migrant to a minority paradigm. Immigration and integration became increasingly linked. In particular, at the end of the 1990s, the large Muslim population triggered debates about Dutch national identity and Dutch norms and values - especially with respect to family, gender and sexuality - as different from those of the Muslim minority group. Moreover, because non-Western immigrants were seen as particularly ill-integrated, measures were taken to select migrants before migration, for example, through the pre-migration integration exam (Bonjour, 2009).

In addition, the income requirements and regulations for family reunification and formation have become stricter since the 1990s. Although before 2004, a stable income of 100 percent of the minimum wage was required, from 2004 on, only migrants with incomes of 120 percent or more of the minimum wage were eligible for family formation, excluding government subsidies. This amounted to $€ 18,200$ per year in 2011 (the year of the survey) before taxes (Leerkes \& Kulu-Glasgow, 2011). Additionally, the income was required to be stable; a migrant's labour contract was required to last for at least one year. However, although migration policies concerning unskilled migrants have become stricter, entry for highly skilled migrants has become easier. In 2004, with the help of the EU, the Kennismigrantenregeling (regulation for knowledge migrants) was implemented to enable competition with Asia and the US for knowledge migrants and to enhance economic growth (WODC, 2009).

Finally, the EU has increasingly influenced national migration policy, as exemplified by the Dublin regulation and EU's readmission agreements of third country nationals. As an EU member state, The Netherlands must comply with the directives and regulations in EU treaties, one of which guarantees the free movement of people and goods between all EU member states. With respect to family migration policy, the EU has brought about two important changes. First, the Dutch government was required to withdraw its income-requirements resolution for refugees wishing to bring over family because it violated the right to family life (Bonjour, 2009). However, that change only applies within the first three months of arrival. After that, refugees are subject to conditions similar to those that apply to labour migrants (Defence for children \& Vluchtelingenwerk Nederland, 2012). Second, by ruling of the European Court, the feitelijke 
gezinsband or effective family bond rule was abolished in 2006 because it was seen as a violation of the European Directive of Family Reunification (2003/86/EC) (Bonjour, 2009).

\subsubsection{Dutch asylum and refugee law}

Considering that Angolans came to The Netherlands predominantly as asylum seekers, I provide a short overview of the most important regulations that apply to them. As in other European countries, the definition of a refugee in the 2000 Dutch migration law, or Vreemdelingenwet 2000, is similar to found in article 1 of the United Nations Convention Relating to the Status of Refugees (CRSR) (as amended by the 1967 Protocol):

"A person who owing to a well-founded fear of being persecuted for reasons of race, religion, nationality, membership of a particular social group or political opinion, is outside the country of his nationality and is unable or, owing to such fear, is unwilling to avail himself of the protection of that country; or who, not having a nationality and being outside the country of his former habitual residence as a result of such events, is unable or, owing to such fear, is unwilling to return to it" (Office of the United Nations High Commissioner of Human Rights, 1954).

In principle, migrants or asylum seekers falling under this definition are granted refugee status in The Netherlands, and therefore receive a temporary residence permit. Refugees receive so-called A status that grants more rights than those conferred by other statuses. Technically, refugees have the same rights as Dutch citizens, except for the right to vote. Refugee status can only be withdrawn under exceptional circumstances, e.g., when the status has been obtained on the basis of incorrect information (Olde Monnikhof \& Tillaart van den, 2003). A permit can also be granted if there are compelling humanitarian reasons to do so. If these can be proven, the applicant receives a status called Vergunning to Verblijf, humanitair (VTV-hum), also called C status. VTV-hum status cannot be withdrawn if the situation in the country of origin improves. VTV-hum status must be extended each year and after 5 years, a residence permit can be obtained. Migrants with A or C status are entitled to social security and student grants (ibid.). Finally, there is a third status called voorwaardelijke vergunning tot verblijf (VVTV), translated as 'conditional permit to stay'. This status is aimed at migrants whose asylum application has been rejected but who cannot be sent back to the country of origin because of the circumstances there. These applicants are given VVTV status which can be converted to VTV-hum status after thee years. Moreover, until January 1, 2003, the Dutch government enforced the so-called driejarenbeleid, translated as the three-yearpolicy. This policy provided that under certain circumstances, asylum seekers who had to wait for more than three years until the Dutch government decided whether they were entitled to refugee status would receive a Dutch residence permit. Although this 
only applied to requests for asylum received before 2000, a significant amount of Angolans were able to stay in The Netherlands through this procedure (Wijk van, 2007).

Also important to the history of Angolan migration to The Netherlands are unaccompanied minors. Unaccompanied asylum seeking minors (UAMs) are asylum seekers under the age of 18 who migrate without parents or other family members. They follow the same procedures as accompanied or adult asylum seekers, but can stay in The Netherlands until the age of 18 , when they may be refused refugee status or the right to stay on humanitarian grounds (i.e., these migrants are special admission policy UAMs, as written within the Vreemdelingencirculaire 1994). Therefore, to obtain UAM status, it did not really matter whether the applicant had a plausible refugee story (Wijk van, 2007), at least if the applicant could not be cared for by family or others in the country of origin. Until 2001, if no adequate care was found in the country of origin within 6 months, the applicant received UAM status for up to 1 year, with a maximum of 2 extensions, resulting in a maximum stay of 3 years. These extensions continued to apply if the UAM reached the age of 18 during the process. However, this UAM status was temporary, meaning that if within the 3 years adequate care was found in the country of origin, UAM status was withdrawn. If no care was found within 3 years, the applicant could receive a residence permit for an indefinite period. For a long time, the Dutch immigration service assumed that for many Angolan UAMs, no adequate care was available in Angola. However, in 2003, the Dutch government and the IOM financed an orphanage in Angola, Mulemba, which made it possible to return Angolan UAMs because it was seen as providing adequate care ${ }^{3}$.

UAMs were placed in special centres for a few months, after which UAMs up to 14 years of age were placed in a foster home, UAMs up to 17.5 years of age were placed in small housing units, and UAMs above 17.5 years of age were placed in asylum seeker centres. The Dutch case was unique in Europe because The Netherlands provided UAMs with practically the same support as was given to orphans (Wijk van, 2007). To help these children integrate, every child was assigned a foster parent, could attend school, received pocket money and a bike, and received student grants. However, in 2001, asylum policies changed drastically. From 15 years of age on, all UAMs were placed in special asylum seeker centres, where they were prepared for eventual return to their countries of origin and were isolated from Dutch society to improve the likelihood of their return (Wijk van, 2007). Moreover, in the UAM policies implemented in 2001, the UAM status was withdrawn when the UAM reached the age of 18. Additionally, changes where made in the policy with respect to what could be perceived as adequate

\footnotetext{
${ }^{3}$ Only 1 Angolan UAM was reported to have been sent to the orphanage, other UAMs who were to have been sent there by the Dutch government ultimately were taken in by family (Wijk van, 2007).
} 
care (less strict rules were implemented that made it easier to return applicants) and from 2001 on, the Dublin Regulation ${ }^{4}$ applied to UAMs.

\subsection{Angolans and Nigerians in The Netherlands}

This section concerns first- and second-generation Angolan and Nigerian migrants ${ }^{5}$ with Dutch and/or Angolan or Nigerian nationality, i.e., both naturalised Angolans/Nigerians and those who have a permanent or temporary residence permit. The figures used are primarily derived from the Dutch Central Bureau for Statistics (CBS), whose numbers include only people registered by Dutch municipal administrations and therefore do not include undocumented migrants.

\subsubsection{Demographic and migration statistics of Angolans and Nigerians in The Netherlands}

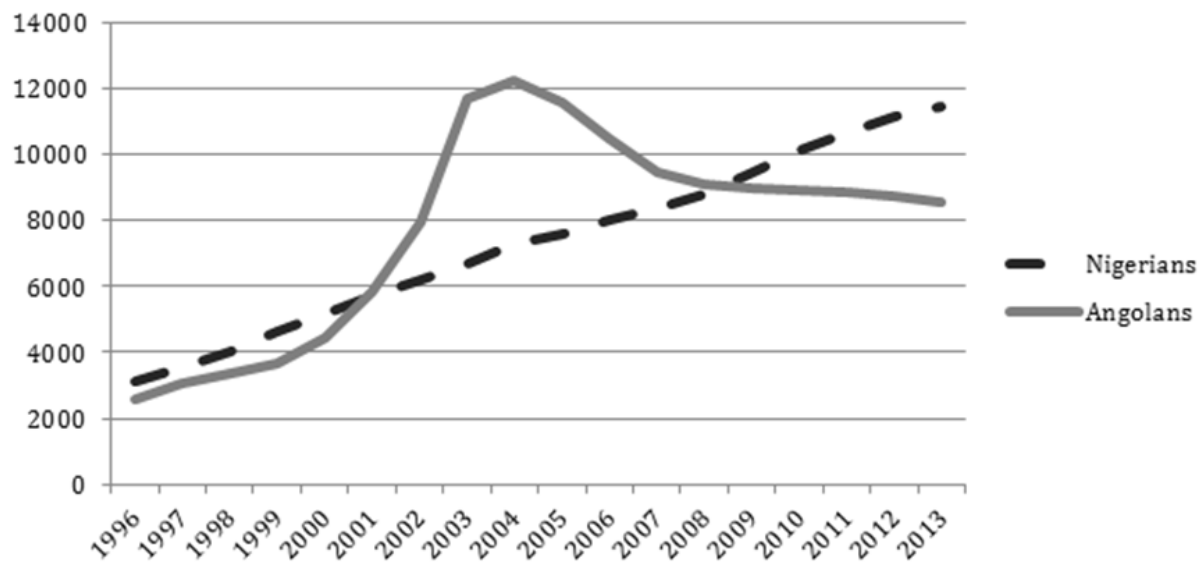

Figure 2.2. Angolan and Nigerian population in The Netherlands from 1996 to 2013 Source: Central Bureau of Statistics (2013).

Figure 2.2 displays the number of Angolans and Nigerians in The Netherlands from 1996 onwards. We can clearly see the upward trend of Nigerian migrants in The Netherlands and the peak in Angolan migrants, as described in section 2.2.1. This drop in Angolan migration has resulted in a negative migration balance from 2004 on, meaning

\footnotetext{
${ }^{4}$ The Dublin Regulation, first brought into force in 1997, prevents asylum seekers from submitting applications in multiple European member states.

${ }^{5}$ First-generation migrants are those born abroad with at least one parent who was born abroad. Secondgeneration migrants are those who were born in The Netherlands and have at least one parent who was born abroad. The second generation's ethnic background is that of the mother's country of origin, unless that is The Netherlands.
} 
that more Angolans left The Netherlands than entered (see Table 2.3). However, Heelsum and Hessels (2006) also have reported that some Angolans who do not receive a residence permit disappear and are reported as having an unknown destination. Most likely, these Angolans still reside in The Netherlands, although they are undocumented. However, in comparison to Nigerians, this proportion is most likely low. Although Nigerian migration shows a positive balance post-1996, that balance is relatively small. Although there is high immigration, there is also high emigration. A significant share of Nigerians attempt to migrate to the UK, where they expect employment to be better and where English is spoken (Heelsum \& Hessels, 2006).

Table 2.3. Migration balance of Angolans and Nigerians in The Netherlands (1995-2012)

\begin{tabular}{|c|c|c|c|c|c|c|}
\hline \multirow[b]{2}{*}{ Year } & \multicolumn{3}{|c|}{ Angolans } & \multicolumn{3}{|c|}{ Nigerians } \\
\hline & Immigration & Emigration & $\begin{array}{l}\text { Migration } \\
\text { balance }\end{array}$ & Immigration & Emigration & $\begin{array}{l}\text { Migration } \\
\text { balance }\end{array}$ \\
\hline 1995 & 687 & 69 & 618 & 235 & 255 & -20 \\
\hline 1996 & 508 & 148 & 360 & 469 & 254 & 215 \\
\hline 1997 & 350 & 151 & 199 & 522 & 252 & 270 \\
\hline 1998 & 337 & 113 & 224 & 595 & 249 & 346 \\
\hline 1999 & 688 & 88 & 600 & 465 & 192 & 273 \\
\hline 2000 & 1248 & 91 & 1157 & 416 & 194 & 222 \\
\hline 2001 & 1907 & 96 & 1811 & 463 & 250 & 213 \\
\hline 2002 & 3514 & 229 & 3285 & 498 & 271 & 227 \\
\hline 2003 & 1171 & 861 & 310 & 562 & 261 & 301 \\
\hline 2004 & 357 & 1163 & -806 & 430 & 345 & 85 \\
\hline 2005 & 163 & 1344 & -1181 & 583 & 414 & 169 \\
\hline 2006 & 123 & 1196 & -1073 & 490 & 372 & 118 \\
\hline 2007 & 148 & 671 & -523 & 522 & 322 & 200 \\
\hline 2008 & 181 & 433 & -252 & 618 & 329 & 289 \\
\hline 2009 & 149 & 390 & -241 & 695 & 362 & 333 \\
\hline 2010 & 164 & 387 & -223 & 664 & 415 & 249 \\
\hline 2011 & 151 & 356 & -205 & 682 & 440 & 242 \\
\hline 2012 & 155 & 408 & -253 & 558 & 499 & 59 \\
\hline
\end{tabular}

Source: Central Bureau of Statistics (2013).

As a result of their placement in different asylum-seeker centres, Angolans are scattered across The Netherlands. In 2002, COA reported that the highest concentrations of Angolans in the asylum-seeker centres were found, in descending order, in Eindhoven, Gilze en Rijen, Nunspeet, Rotterdam and Amsterdam (Brons \& Schaap, 2002). However, increasing numbers of Angolans are moving to The Netherlands' largest urban areas, including Rotterdam, The Hague and Amsterdam. Most Nigerians are located in the provinces of North and South Holland, primarily in the cities of, in descending order, Amsterdam, The Hague, Rotterdam and Utrecht.

Because both the Angolan and Nigerian migration to The Netherlands is quite recent, it has resulted in relatively young populations. Figure 2.3 presents the data for 
2011, the year the survey was taken. The fact that many Angolans entered The Netherlands as UAMs is an additional factor, which is also reflected in the peak of Angolans in their mid- and late twenties shown in Figure 2.3. These are the UAMs who entered The Netherlands during the war. As a result, the second generation of (in particular) Angolans was for a long time relatively small, although the number is growing. In 2011, 45 percent of the Nigerian population and 34 percent of the Angolan population was second generation and thus, was born in The Netherlands. Additionally, from the beginning, men have outnumbered women in the Angolan population in The Netherlands, especially when looking at the percentage of UAM boys versus girls. In 2002, for example, 72 percent of the Angolan UAMs registered with the central organ shelter asylum seekers (COA) were boys (Brons \& Schaap, 2002). Most of these boys were older than 14 in 2002. The overrepresentation of men might be the result of boys fleeing forced military service in Angola. At the beginning of Nigerian migration to The Netherlands, men were also in the majority; however, over time, there has been a feminisation of migration whereby sex ratios have evened out. In 1996, 35 percent of Nigerian migrants were female, but by 2011 this increased to 46 percent.

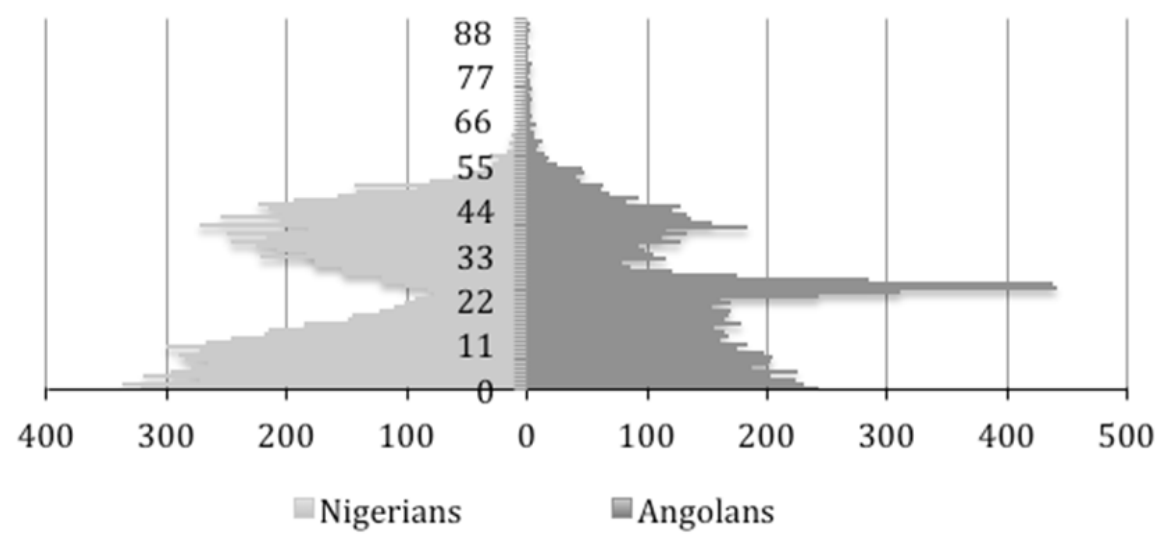

Figure 2.3. Age diagram of the Nigerian and Angolan population in The Netherlands in 2011 Source: Central Bureau of Statistics (2013).

Nigerians and Angolans in The Netherlands seem to differ in household structure and marital status (see Figure 2.4). In 2011, approximately 10 percent of the Angolans headed single-parent households, compared to only 5 percent of the Nigerian and 2.5 percent of the native Dutch population, and in all groups, such parents were primarily women (Central Bureau for Statistics, 2013). This gender division is quite common and can also be found among the Nigerian and Dutch population, where women headed, respectively 88 and 80 percent of the single-parent households in 2011. However, amongst the Angolan population, the proportion is 92 percent, which translates to 19 
percent of the total Angolan female population being single parents, compared to only 4 percent of the native Dutch population (Central Bureau for Statistics, 2013). This could be related to the fact that Angolan girls have children relatively young compared to other migrant groups in The Netherlands (Heelsum, 2005).

Compared to other new immigrant groups, a high proportion of Nigerians is married and has children, although in recent years, the share of married first-generation Nigerians has declined (Heelsum \& Hessels, 2006). Indeed, although married people account for only 10 percent of the Angolan population in The Netherlands, they account for 17 percent of the Nigerian population (Central Bureau for Statistics, 2013). According to Heelsum \& Hessels (2006), this is the result of the fact that Nigerians are more likely to arrive as the spouse of a Nigerian migrant already residing in The Netherlands. Compared to other new immigrant groups, a high share of Nigerians are married and have children, although in recent years, the share of married first-generation Nigerians has declined (Heelsum \& Thomas, 2006). In both groups, there is a large proportion of single men, which is more pronounced in the Nigerian sample.

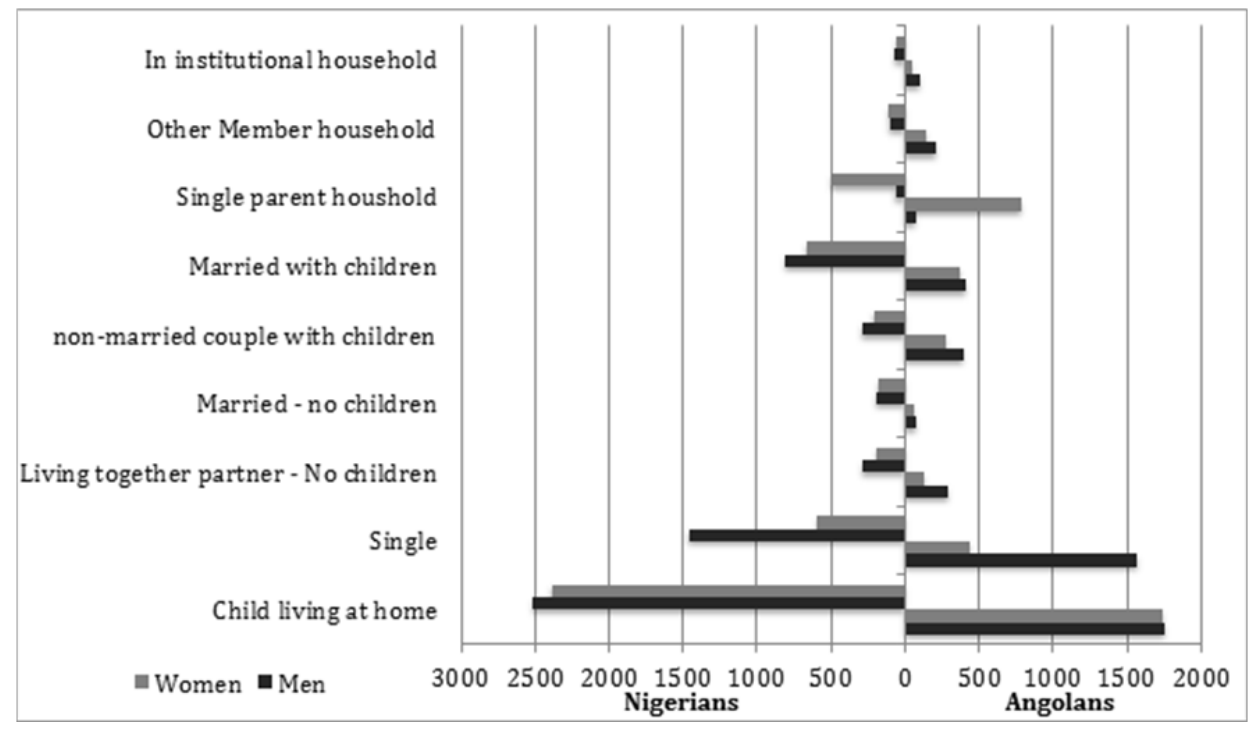

Figure 2.4. Household structures of Angolans and Nigerians in The Netherlands (2011).

Source: Central Bureau of Statistics (2013).

\subsubsection{Labour market position of Angolans and Nigerians in The Netherlands}

Because the migrant groups under study do not belong to the major migrant groups in The Netherlands, and because sub-Saharan African migration to The Netherlands is under-researched, there is relatively little data on these groups, particularly with respect 
to education obtained, labour market position and income. However, we can obtain an indication of the position of Angolans and Nigerians in The Netherlands with the data collected in this study and in other small studies conducted in The Netherlands.

First, although there are no official statistics on the education levels of the populations I study, Warmerdam and van den Tillaart (2002) studied education levels of asylum seekers in The Netherlands with records of the Dutch immigration service. As indicated above, asylum seekers are only a small part of the Nigerian population and hence these numbers should be treated with caution. Warmerdam and van den Tillaart indicate that 25 percent of Nigerian migrants in The Netherlands obtained a higher education before migrating, which is high compared to other non-Western immigrant groups in The Netherlands. Furthermore, the OECD reports that more than 50 percent of Nigerians living in OECD countries have received a tertiary education (OECD, 2008). This same report, however, also states that migrants from Angola lag behind other migrant groups from sub-Saharan Africa in terms of educational performance. This is reflected in some figures reported by the OECD, which reports that in 2000, 16 percent of the 261,000 Nigerian expatriates in OECD countries obtained a primary education, and 54.7 percent obtained a tertiary education. In contrast, 53.5 percent of the 196,200 Angolan expatriates obtained primary education, while only 19.7 percent obtained tertiary education. This is reflected in the TCRAf-Eu data, in which I find that the majority of Nigerians have a university education, and only a very few have obtained less than a secondary education. Conversely, only 6 percent of the Angolans in the TCRAf-Eu data have obtained a university degree. However, in contrast to the numbers obtained by the OECD, 62 percent of these Angolans have obtained at least a tertiary degree (i.e., an MBO diploma). This discrepancy between the TCRAf-Eu data and that of the OECD stems from the fact that although many Angolans had not obtained a great deal of education prior to entering The Netherlands, the majority were able to obtain additional education in The Netherlands because they came as unaccompanied minors to whom the Dutch government offered education.

Although little is known about the labour market participation of Angolans and Nigerians in The Netherlands, we can observe some differences based on the TCRAf-Eu data and on that of a small study by van Heelsum (2005). In general, asylum seekers are shown to be more slowly integrated into the labour market than other migrant groups because their primary reason for migrating was economic, because they do not always have appropriate skills or qualifications, because they are not allowed to work when they are going through the asylum process and because war traumas can interfere with labour market participation (Heelsum, 2005). Moreover, because of the war, many Angolans could not attend school and only began their studies after coming to The Netherlands as UAMs. However, the result of this situation is that those Angolans were able to study at Dutch schools whose qualifications are recognised in The Netherlands and that they understand the Dutch language. Although Nigerians in The Netherlands 
are highly educated, their qualifications are often not recognised and they often have difficulty speaking the Dutch language. As a result, many Nigerians are unsatisfied and frustrated with the job market in The Netherlands, in which they often perform unskilled labour (Heelsum \& Hessels, 2006).

Of the Nigerians who entered The Netherlands in 1999, and thus comprised the first generation in 1999 only, 51 percent were registered as employed and 22 percent received a benefit from the Dutch government in 2006 (Central Bureau for Statistics, 2013). In comparison, this number is similar to Moroccans and Turks, who as a group have been in The Netherlands much longer, and it is similar to the average for nonWestern immigrants. Thus, in comparison to other immigrant groups, Nigerians are doing fairly well on the job market. Unfortunately, we do not have this information for the Angolan population. However, if we look at the TCRAf-Eu data, we see that although 22 percent of the Nigerians in the sample report unemployment, only 3 percent of the Angolan population do. Thus, there is a big discrepancy.

A small study by van Heelsum and Hessels (2006) indicates that many Nigerians are frustrated and unsatisfied with the job market in The Netherlands, but in that study, only a limited number of Nigerians were interviewed. As indicated above, many Nigerians in The Netherlands are highly educated, but this is not reflected in the jobs they hold. According to the TCRAf-Eu sample, most Nigerians work as domestic workers, production workers, and accountants. Angolans work primarily in the fields of mechanics, administration and care. Although only 18 percent of the Angolans in the sample work in unskilled labour, this number 35 percent for the Nigerians. One of the reasons for this result could be Nigerians' low proficiency in the Dutch language. However, it is interesting that more Nigerians (19 percent) than Angolans (11 percent) are working in higherlevel occupations. A reason for this could be that for the higher-level occupations, Nigerians' knowledge of the English language is sufficient and may be even necessary (for example, at universities and international companies), whereas this is often not the case for skilled labour, which requires knowledge of Dutch. Moreover, we must note that 16 percent of the Nigerians in the TCRAf-Eu sample are undocumented and might find it difficult to obtain a job, especially in skilled labour and higher-level occupations.

\subsection{Conclusion}

This chapter has shown that The Netherlands, an immigration country since the second half of the last century, has changed migration policy drastically in the last decades. It is less welcoming to current migrants than it was in the 1960s and 1970s, when large flows of Mediterranean and North African migrants entered. Stricter regulations concerning family reunification and formation and difficulties obtaining official status are just two examples of this change. In this context, the Angolans and Nigerians part of this study 
migrated to The Netherlands, which affects both the formation of transnational families and potential reunification.

Although both groups entered The Netherlands in this changing political climate they came to The Netherlands in different ways and therefore were received differently by Dutch society. Angolans came primarily as asylum seekers escaping the war that raged in Angola until 2002, and Nigerians mainly came as economic migrants and through family reunification/ formation. This chapter has shown that these migration paths shaped the two groups' reception and consequently their life opportunities in The Netherlands. Although both groups are doing fairly well on the labour market in comparison to other non-Western migrant groups, Nigerians are frustrated because of their low Dutch language proficiency and because their qualifications are often not recognised. Although on average Angolans have a lower level of education, they often speak Dutch and their qualifications are recognised because they were educated in The Netherlands when they arrived as UAMs. Another important difference that emerged in this chapter is that although a large proportion of Nigerians are undocumented, many Angolans were able to obtain residence permits or Dutch citizenship through the asylum process. In the next chapter I will investigate whether these differences between Angolans and Nigerians are also important to consider when studying transnational families. 
CHAPTER 3.

Data, methodology \& sample characteristics 



\subsection{Introduction}

This chapter will introduce the data and methods that are used throughout this dissertation and will provide a first account of the differences between transnational and nontransnational parents in the data. First, I discuss the sampling procedure, the data collection and data-entry procedures and the methods important to all empirical chapters. Second, I present the characteristics of the sample and study the differences between Angolan and Nigerian families part of the data. Third, I will present the characteristics of the transnational families part of the data and explore the reasons for separation and study how care is arranged. Finally, I examine characteristics that distinguish transnational families from non-transnational families and explore ways in which they might affect the transnational child raising arrangements.

\subsection{Data \& methods}

\subsubsection{Sampling procedure}

This dissertation uses data collected for the TCRAf-Eu project, which was funded by NORFACE ${ }^{6}$ (Mazzucato, 2009b). The aim of this project is to understand how transnational child raising arrangements affect the life opportunities of children who remain in the country of origin, their migrant parents and their caregivers. In addition, it studies how these arrangements are affected by migration laws in Europe and the institution of child fosterage in Africa, and how schools in African countries are affected by these arrangements. Finally, it investigates how the different sending and receiving country contexts affect the functioning and outcomes of transnational child raising arrangements with respect to different actors. To enable the investigation of how sending and receiving contexts affect the functioning of transnational families, a cross-country comparison is included. Five matched case studies with a common analytical framework and methods are included; Portugal - Angola, The Netherlands - Angola, Ireland Nigeria, The Netherlands - Nigeria, and The Netherlands - Ghana. In addition, various methods are used to triangulate results and to obtain a comprehensive understanding of transnational family life, such as ethnographic work and quantitative analysis with survey data. This dissertation makes use of the TCRAf-Eu parent survey conducted on Angolans and Nigerians in The Netherlands. I was involved in the questionnaire devel-

\footnotetext{
${ }^{6}$ NORFACE stands for New Opportunities for Research Funding Agency Co-operation in Europe and is a consortium of fourteen research councils (including the Dutch NWO) created to increase co-operation in research and research policy in Europe. This project [NORFACE grant number 315]. was funded by the research programme 'Migration in Europe - Social, Economic, Cultural and Policy Dynamics'.
} 
opment and in all stages of the data collection and data entry regarding Angolan and Nigerian parents in The Netherlands.

Between November 2010 and July 2011, approximately 20 interviewers conducted interviews with Angolan and Nigerian parents in The Netherlands living in the cities of Amsterdam, The Hague and Rotterdam. Because no baseline survey exists, we could not employ a random sampling strategy, but to allow for a diverse sample we asked the interviewers to use different gateways into the community to find respondents from various strata of society, e.g., through personal contacts, churches, hometown organisations, cultural projects, city and government departments, along with the use of snowball sampling. Moreover, because we hired interviewers from different ethnic communities (including both migrants and non-migrants), cities, age groups, and social strata, a wide variety of respondents were reached.

Because we wanted to learn more about transnational families and the effects of transnational child raising arrangements on migrant parents who live separated from their children, we used purposive sampling to include 300 migrant parents per group, divided into one group of 150 migrant parents with at least one child living in the country of origin and another group of 150 migrant parents with children in The Netherlands. This latter group acts as a comparison group, enabling me to study specific characteristics of transnational parents and to isolate effects, i.e., to study whether the effects found are particular to transnational parents or apply to migrant parents in general. The study includes only migrant parents with children under the age of 21 because as a group those parents are expected to remain involved in parenting and their children are still somewhat dependent on caregivers. In addition, it parallel's the child survey part of the TCRAf-Eu project, where children up to 21 where interviewed in secondary schools given grade repetition. Furthermore, the parents were required to have spent at least one consecutive year in The Netherlands and to have settled in The Netherlands at age 18 or older. We aimed to include an equal number of men and women across different age groups. Finally, only 1 migrant parent per child was interviewed.

As the transnational families literature indicates that sex of the migrant parent, legal status, and socio-economic status are of importance for transnational family life, we wanted to ensure enough respondents in each of these categories to enable comparison and statistical analyses of these differences. To ensure that a varied sample was obtained, I kept weekly reports in which the total amount of questionnaires administered, the number of men and women interviewed, the number of documented/undocumented migrants, the highest year of education attained, the age of the children and the number of respondents in transnational and non-transnational families was recorded. When necessary, I asked the interviewers to target particular groups, e.g., only men with children in The Netherlands. 
The interviewers received extensive interview training, in which my colleague and I explained the aim of the research, identified the type of migrants we wanted to target, gave suggestions in which locations to reach potential respondents, went to the questionnaire step-by-step, practiced the questionnaire with the interviewers, and provided feedback on the first round of interviews performed by the interviewers. I also created a detailed survey manual in which the interview procedure was explained step-by-step, key definitions were given, instructions were given on how to conduct the questionnaire in general and for specific questions in particular. The interviewers and I were in close contact during the whole fieldwork period so I was aware of what was happening in the field and I could provide direction and assistance when needed.

To ensure data consistency and reliability during the fieldwork period, a research assistant and I proofread each questionnaire for errors and inconsistencies. When abnormalities were noted, interviewers were contacted to provide the missing information or explain the irregularities, and at times they needed to contact the respondent. Once proofreading and necessary corrections were completed, the data were entered into CSPro, i.e., a Census and Survey Processing System, and transformed into a STATA database. Finally, I cleaned the data using STATA 11.2.

In general, it proved difficult to find Angolan respondents. Only 2 interviewers were able to perform more than 5 interviews with Angolans. First, this is because unlike other migrant groups, Angolans are not very well organised in associations as a result of their placement in asylum-seeker centres all over The Netherlands. Additionally, unlike many other migrant groups, Angolans do not have their own churches where they can be easily contacted. Subsequently, we had to make some adaptations. Although we intended to look for respondents solely in Rotterdam, Amsterdam and The Hague, we decided to include Angolans from all over The Netherlands. Furthermore, we only wanted to include respondents who had moved to The Netherlands at age 18 or over. However, because many Angolans came to The Netherlands as unaccompanied minors and the Angolan population in The Netherlands is therefore relatively young, we decided to lower the age to 16 for this migrant group. With these adaptations, we were able to reach our goal of 300 respondents. 
Angolans

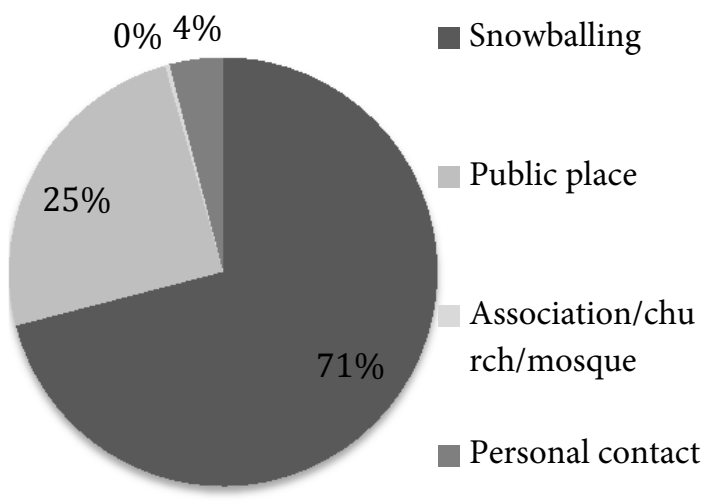

Nigerians

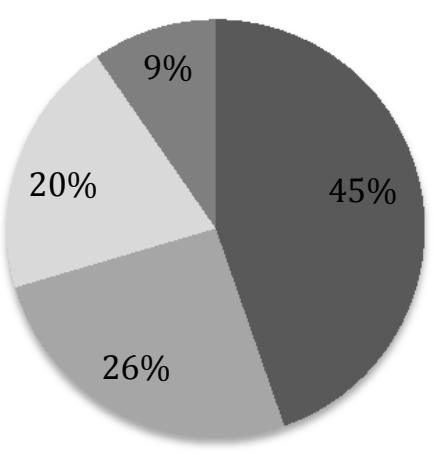

Figure 3.1. Contact source respondents TCRAf-Eu parent-survey Source: TCRAf-Eu parent survey Netherlands, 2010-2011.

The majority of the Angolan respondents were found through snowball sampling (71 percent, Figure 3.1); only one Angolan was found through an organisation/ association. Some Angolan respondents were found in public places (25 percent), e.g., in the waiting room of the Angolan consulate or during the Rotterdam carnival. Additionally, in the Nigerian sample, many of the respondents (although at 45 percent, not the majority) were found through snowballing. One-fifth of the Nigerians were found through an association, primarily through church. Additionally, a significant number of Nigerians was found in public places, such as Nigerian shops and on the street in migrant neighbourhoods. Although we did not record the number of rejections, each interviewer was asked to indicate the willingness of the respondent to participate. The majority of the respondents were easily persuaded to participate (84.51 percent of the Nigerians and 79.93 percent of the Angolans), and only a few were very difficult to persuade (1.35 percent of the Nigerians and 1.97 percent of the Angolans).

\subsubsection{The questionnaire}

The questionnaire was developed with the specific research questions in mind and was tested and adapted before the survey was implemented. The questionnaire consists of over a 100 questions divided in various modules ${ }^{7}$. Some questions needed to be only answered by transnational parents and others by non-transnational parents, although the former group had significantly more questions to answer. The questionnaire con-

\footnotetext{
${ }^{7}$ For the questionnaire refer to www.tcra.nl
} 
tained questions about the respondent and his or her partners and specific questions on each of the children of the respondent. The interviews lasted on average an hour for non-transnational parents and one-and-a-half hour for transnational parents. Alongside the questionnaire an "Ageven" (Age Event) grid was used to date specific events of interest: changes in partner, housing location, migration status and birth and death of a child. For particular questions, the interviewee could refer to a calendar year or his or her age to define these events, which were recorded in a special grid. This made it easier for the respondent to track certain life history events and for the interviewer to validate the timing of these events.

The questionnaire contained 20 modules. Each module focussed on a particular aspect of the respondent's life: basic demographic characteristics, partner characteristics, family history, residential history of him/herself and his/her biological children, social networks and support, health and well-being, education and economic activity, labour market performance, citizenship and residence permits, and a module with attitudinal questions. A module on children collected information on each of the children under the age of 21: the age of the child, the country of residence, the whereabouts of the other biological parent, the relationship the parent has with each of these children, health, school performance, and whether the respondent tried to bring the child to The Netherlands if born abroad. A special module collected information on children under the age of 21 that live outside of The Netherlands. This module contained questions on the amount of contact that is maintained, remittances sent, the last time the respondent has seen the child, and questions on the caregiver.

Dealing with vulnerable migrant populations, including undocumented migrants necessitates careful ethical considerations. Also, as described above, the questionnaires contain personal and confidential data on respondents' family lives, health, employment and migrant trajectory. At the time of research, the faculty and university did not have an internal review board for the social sciences and humanities. This research, however, followed the ethical codes and procedures as laid down in the Dutch Code of Conduct for Scientific Integrity ${ }^{8}$ and the Dutch Code of Conduct for the use of personal information in Scientific research ${ }^{9}$. We ensured the anonymity of respondents in several ways. First, the interviewers received an intensive training in which we discussed confidentiality and anonymity and explained the rules. This was also recorded in the interview guide interviewers received at this training. Second, we did not collect home addresses, we only recorded the city where they lived. The respondent could provide his or her phone number, but few respondents did. The only person who could get in contact with the respondent was the interviewer and they did not provide these details to us. Third, while the respondents where asked to provide a first name at the start of the interview, we told them this could also be a pseudonym. These names were needed to contact the inter-

\footnotetext{
${ }^{8}$ De Nederlandse Gedragscode Wetenschapsbeoefening of the Vereniging van Universiteiten (VSNU)

${ }^{9}$ Wet Persoonsgegevens
} 
viewer when certain information was missing, but these names were deleted in the final dataset. In the dataset that is open to researchers outside of our team, information about the interviewers and interviewees is fully anonymised.

Another issue concerns informed consent. We decided not to use informed consent forms, but opted for oral consent. Consent forms can be problematic for lower educated respondents and can be intimidating for immigrants because they often resemble legal documents that are related to their immigrant status. Also, respondents might feel that they are signing away their rights to withdraw from the study (Birman, 2006). Therefore, we opted for oral consent and informed the respondents about their rights. The interviewers explained the project, informed the respondents that the interview was confidential, that they were not obliged to answer questions if a question made them feel uneasy and they could stop the interview at any time. The respondents also received an information brochure about the project, which contained the website of the project and the contact details of the main researchers in case they wanted to contact us. This website also hosts a special section for respondents with more information on the project and some first results ${ }^{10}$.

\subsubsection{Methods}

In this dissertation, various methods are used, each of which will be discussed. All analyses have been performed in STATA 11.2. The current chapter uses various descriptive analyses. First, to compare transnational to non-transnational parents and to determine whether migrant, socio-economic and demographic characteristics are dissimilar for these two groups of parents, I present descriptive tables that display Pearson chi-square tests. The same is done for other comparisons. A Pearson chi-square test essentially assesses whether two variables are independent of each other and tests how likely it is that an observed distribution has arisen by chance. However, because at times I have a small number of observations per category, I also conducted the Fisher's exact test, which can be interpreted in a manner similar to the Pearson chi-square test. Although I present data in cross-tabulations and show chi-square tests for the entire table containing multiple categories, I have also used dummy variables to check the specific categories for which differences are found with respect to the independent variable. Furthermore, with respect to continuous variables, I have used independent sample t-tests, a test that compares the means of two groups and tests whether these significantly differ.

The descriptive analyses of this chapter form an important stepping stone for the rest of the dissertation because they indicate which factors are important to consider in the study of transnational families. In Chapters 4 to 6 , various forms of regression analysis are conducted to assess the effects of transnational child raising arrangements

${ }^{10}$ Both the brochure and information for respondents can be found at www.tcra.nl 
on the lives of transnational parents in The Netherlands. In Chapter 4, logistic regression is utilised; in Chapter 5, ordinary least squares (OLS) regressions with robust standard errors are performed; and in Chapter 6, binary mediation analyses are employed. Ultimately, these analyses allow me to investigate whether certain associations exist between transnational family life plus other individual characteristics and the outcome variables. More importantly, even though I cannot test causality, regression analyses allow me to consider various factors and to study the interplay of these factors through interaction effects. This enables me to investigate whether transnational parents and non-transnational parents show differences in their well-being, and whether these differences can be accounted for by transnational separation or whether other characteristics of transnational parents explain the differences.

Depending on the specific outcome variable and the type of question asked, different samples are used. Because in Chapter $4 \mathrm{I}$ investigate which factors are important in maintaining a good transnational-parent child relationship, only a sub-sample of transnational parents is used. In this analysis, Angolans and Nigerians are included in one sample to increase statistical power, and interactions are included to test whether associations differ for the two groups. In the other empirical chapters, I study the effect of transnational family separation on subjective well-being and job outcomes using a comparison group of non-transnational parents. The sample used in Chapter 5 includes all transnational parents, including transnational parents who have both children residing in The Netherlands and the country of origin. In Chapter 6 parents who have children both in The Netherlands and in the country of origin are excluded because I test multiple mediation paths and opposite hypotheses. Moreover, I perform separate analyses for each migrant group in Chapters 5 and 6 because subjective well-being, which is an outcome variable in Chapter 5 and a mediating factor in Chapter 6, may be assessed differently by people from diverse cultures (Diener, Oishi, \& Lucas, 2003). Multicollinearity tests performed for each analysis indicate that multicollinearity among the independent variables is not a serious concern.

\subsection{Sample characteristics}

\subsubsection{Socio-demographic characteristics sample}

The sampling procedure resulted in 308 Angolan and 302 Nigerian respondents, of whom 306 and 296 respondents, respectively, met the requirements. As displayed in Tables 3.1 and 3.2, 52.29 percent of the Angolan respondents are male; their ages range from 26 to 63 years with a mean of $34(\mathrm{SD}=6.23)$. The Angolan respondents primarily belong to the Bakongo (26.64 percent), Kimbundu (16 percent) and Ovimbundu (15 percent) ethnic groups. Most of them reported that they are religious, with the majority belonging to the Catholic Church. Of the Nigerian sample, 59 percent are male; their 
ages range from 26 to 59 years of age with a mean of $38.71(\mathrm{SD}=6.08)$. The Nigerian respondents primarily belong to the Igbo (42 percent) and Yoruba (37 percent) ethnic groups. Most of them reported that they are religious and belong to a Christian denomination.

The majority of the Angolan respondents (56 percent) have received some vocational training in The Netherlands (MBO level), which is in line with other research on Angolans in The Netherlands. In contrast, the majority of the Nigerian respondents have a university degree (52 percent) and therefore on average, they are highly educated. This result is in line with other research reporting on Nigerians in The Netherlands (Heelsum \& Hessels, 2006; Warmerdam \& van den Tillaart, 2002). The household net income of the Angolan respondents is quite high: more than half of the sample has an income of more than 1,500 euros per month. Nigerians are more evenly spread out over the different income categories.

Furthermore, 54.58 percent of the Angolan parents have all of their children in The Netherlands, 16.67 percent have some children in The Netherlands and some in Angola, and 28.72 percent of Angolan parents have all of their children in Angola. In the Nigerian sample, the results are rather similar: 55.56 percent of the Nigerian parents have all of their children in The Netherlands, 10.77 percent have some children in The Netherlands and some in Nigeria, and 33.67 percent of the Nigerian parents have all of their children in Nigeria. For most of the analyses, I combined the respondents with some children in Angola or Nigeria and some in The Netherlands with the group of respondents whose children all live in Angola or Nigeria.

On average, the respondents have 2.02 children, with a minimum of 1 and a maximum of 6 . In the Nigerian sample 3 transnational parents has their first child before they reached the age of 18. In the Angolan sample this is significantly higher. In total 25 Angolans parents reported to have children before the age of 18 (8 percent of the sample); 16 of these are transnational parents and 9 are non-transnational parents. Furthermore, most respondents are either in a relationship or married, though Nigerians are married significantly more often than Angolans. Only a few respondents are divorced, only one respondent is widowed and 48 Angolan and 35 Nigerian respondents are single. It is noticeable that amongst Angolans, significantly more female respondents (23.45 percent) than male respondents ( 8.75 percent) are single. These figures approach the earlier-reported CBS numbers on the total Nigerian and Angolan population in The Netherlands. The majority of the Nigerian respondents live in Amsterdam, The Hague is the city where the second-largest number of respondents is found and only a small percentage of the respondents live in Rotterdam or Almere. The Angolan respondents come from various cities, but the largest proportion lives in Amsterdam, Utrecht or Rotterdam. 
Table 3.1. Basic descriptives of categorical variables

\begin{tabular}{|c|c|c|c|c|}
\hline & \multicolumn{2}{|c|}{ Angolans } & \multicolumn{2}{|c|}{ Nigerians } \\
\hline & $\mathrm{N}$ & $\%$ & $\mathrm{~N}$ & $\%$ \\
\hline \multicolumn{5}{|l|}{ Family type } \\
\hline All children live in The Netherlands & 167 & 54.58 & 165 & 55.56 \\
\hline Some children live in The Netherlands some in origin country & 51 & 16.67 & 32 & 10.77 \\
\hline All children live in the origin country & 88 & 28.76 & 100 & 33.67 \\
\hline \multicolumn{5}{|l|}{ Sex } \\
\hline Male & 160 & 52.29 & 174 & 58.59 \\
\hline Female & 146 & 47.71 & 123 & 41.41 \\
\hline \multicolumn{5}{|l|}{ Legal status } \\
\hline Documented & 302 & 99.02 & 248 & 83.78 \\
\hline Undocumented & 3 & 0.98 & 48 & 16.22 \\
\hline \multicolumn{5}{|l|}{ Level of Education } \\
\hline No schooling & 13 & 4.26 & 1 & 3.40 \\
\hline Primary & 14 & 4.59 & 8 & 2.69 \\
\hline Junior secondary & 17 & 5.57 & 24 & 8.08 \\
\hline Senior secondary & 71 & 23.28 & 60 & 20.20 \\
\hline Vocational & 170 & 55.74 & 50 & 16.84 \\
\hline University & 20 & 6.56 & 154 & 51.85 \\
\hline \multicolumn{5}{|l|}{ Marital Status } \\
\hline Single & 48 & 15.74 & 35 & 11.78 \\
\hline Married & 140 & 45.90 & 208 & 70.03 \\
\hline Relationship & 114 & 37.38 & 47 & 15.82 \\
\hline Divorced & 3 & 0.98 & 6 & 2.02 \\
\hline Widowed & 0 & 0 & 1 & 0.34 \\
\hline \multicolumn{5}{|l|}{ Income } \\
\hline 0-500 euro & 7 & 2.34 & 42 & 17.43 \\
\hline 500-1000 euro & 32 & 10.70 & 33 & 13.69 \\
\hline $1000-1500$ euro & 89 & 29.77 & 53 & 21.99 \\
\hline 1500-2000 euro & 143 & 47.83 & 39 & 16.18 \\
\hline More than 2000 euro & 28 & 9.36 & 74 & 30.71 \\
\hline \multicolumn{5}{|l|}{ Religion } \\
\hline No religion & 7 & 2.30 & 2 & 0.67 \\
\hline Muslim & 0 & 0.00 & 17 & 5.72 \\
\hline Catholic & 217 & 71.38 & 76 & 25.59 \\
\hline Protestant & 28 & 9.21 & 40 & 13.47 \\
\hline Charismatic / Pentecostal & 34 & 11.00 & 153 & 51.52 \\
\hline Other & 18 & 6.30 & 8 & 3.30 \\
\hline \multicolumn{5}{|l|}{ Ethnicity } \\
\hline None & 34 & 11.18 & 3 & 1.01 \\
\hline Bakongo (Angolans) / Hausa (Nigerians) & 91 & 29.93 & 19 & 6.40 \\
\hline Ambundu (Angolans) / Yoruba (Nigerians) & 27 & 8.88 & 110 & 37.04 \\
\hline Ovimbundu (Angolans) / Igbo (Nigerians) & 46 & 15.00 & 124 & 41.75 \\
\hline Kimbundu (Angolans) & 50 & 16.00 & & \\
\hline Other & 56 & 18.42 & 40 & 13.47 \\
\hline Total & 306 & 100.00 & 297 & 100.00 \\
\hline
\end{tabular}

Source: TCRAf-Eu parent survey Netherlands, 2010-2011. 
Table 3.2. Basic descriptives of continuous variables

\begin{tabular}{|c|c|c|c|c|c|c|c|c|c|c|}
\hline & \multicolumn{5}{|c|}{ Angolans } & \multicolumn{5}{|c|}{ Nigerians } \\
\hline & $\mathrm{N}$ & Mean & $\mathrm{SD}$ & Min & $\operatorname{Max}$ & $\mathrm{N}$ & Mean & $\mathrm{SD}$ & Min & Max \\
\hline Age migrant parent in years & 306 & 34.0 & 6.35 & 23 & 63 & 297 & 38.71 & 6.08 & 26 & 59 \\
\hline Number of biological children & 306 & 2.02 & 1.22 & 1 & 6 & 297 & 2.02 & 0.88 & 1 & 6 \\
\hline Age children & 571 & 7.79 & 5.81 & 0 & 21 & 574 & 8.72 & 5.32 & 1 & 21 \\
\hline
\end{tabular}

Source: TCRAf-Eu parent survey Netherlands, 2010-2011.

\subsubsection{Migration pattern respondents}

The majority of the Angolan respondents came to The Netherlands during the war (the average length of residence is 14 years, $\mathrm{SD}=4.25$ ). As displayed in Table 3.3, the majority of the Angolans in the TCRAf-Eu sample therefore came to The Netherlands through the asylum procedure and entered The Netherlands without any visa or permit. Ninetynine percent of the respondents applied for asylum in The Netherlands, which proved to be successful for the majority, because 95 percent received refugee status at some point in time. Ultimately, the majority of those who obtained refugee status ( 247 respondents, or 81 percent of the sample) obtained Dutch nationality in the end. As displayed in Table 3.4, for most of the respondents, this meant that they have had 3 periods of residence permits: no visa upon entrance, refugee status (a form of residence permit), and Dutch nationality (captured in the category do not need residence permit). Although not presented because of space limitations, most of the respondents were quite young when entering The Netherlands, with a mean of 20 years old ( $\mathrm{SD}=6.64)$. Thirty percent of the TCRAf-Eu sample came to The Netherlands at age 16 or 17 and thus were unaccompanied minors, including roughly the same number of transnational and nontransnational parents. Finally, the majority of the respondents want to stay in The Netherlands during the next 5 to 10 years (79 percent), and we see no differences between transnational and non-transnational parents.

As displayed in Table 3.3, the majority of the Nigerians in the TCRAf-Eu sample came to The Netherlands on a tourist or business visa ( 86 percent). Only a few already had a residence permit upon entrance to The Netherlands. Within a few years, many of the respondents' visas changed into residence permits, but some respondents were not able to obtain residents permits and became undocumented. At the moment of data collection, 16 percent of the respondents were undocumented; the rest of the respondents had a visa, a residence permit or Dutch nationality (and thus did not need a permit). Few Nigerian migrants in the TCRAf-Eu sample came to The Netherlands through asylum. Eighteen percent of the sample sought asylum outside of Nigeria, of which 75 percent applied in The Netherlands and 25 percent applied in other European countries such as Belgium, Germany and Spain (not displayed). Of these respondents, 47 percent were denied status and 45 percent received a refugee status. Finally, Nigerian respondents have been living in The Netherlands for an average of 8 years, with a range of 1 to 32 years. 
Table 3.3. Basic descriptives first and second period of residence permit

\begin{tabular}{|c|c|c|c|c|}
\hline & \multicolumn{2}{|c|}{ Angolans } & \multicolumn{2}{|c|}{ Nigerians } \\
\hline & $\mathrm{N}$ & $\%$ & $\mathrm{~N}$ & $\%$ \\
\hline \multicolumn{5}{|l|}{ First period of residence permit } \\
\hline Not Need any Residence Permit & 2 & 0.66 & 2 & 0.68 \\
\hline Entered through visa & 55 & 18.03 & 256 & 86.49 \\
\hline Entered with a residence permit & 8 & 2.62 & 19 & 6.42 \\
\hline Did not have a permit upon entrance & 240 & 78.69 & 19 & 6.42 \\
\hline Total & 305 & 100 & 296 & 100 \\
\hline \multicolumn{5}{|l|}{ Second period of residence permit } \\
\hline Not Need any Residence Permit & 3 & 1 & 12 & 4.67 \\
\hline Has visa & 3 & 1 & 1 & 0.39 \\
\hline Has a residence permit & 274 & 91.64 & 177 & 68.87 \\
\hline Does not have a permit or visa & 19 & 6.35 & 67 & 26.07 \\
\hline Total & 299 & 100 & 257 & 100 \\
\hline \multicolumn{5}{|c|}{ When you lived outside Angola/Nigeria, did you seek asylum? } \\
\hline Yes & 286 & 94.7 & 53 & 18.09 \\
\hline No & 16 & 5.3 & 240 & 81.91 \\
\hline Total & 302 & 100 & 293 & 100 \\
\hline \multicolumn{5}{|l|}{ Granted refugee status? } \\
\hline Yes, status obtained & 272 & 95.1 & 23 & 45.1 \\
\hline No status denied & 12 & 4.2 & 24 & 47.06 \\
\hline Not received an answer yet & 2 & 0.7 & 4 & 7.84 \\
\hline Total & 286 & 100 & 51 & 100 \\
\hline
\end{tabular}

Source: TCRAf-Eu parent survey Netherlands, 2010-2011.

Table 3.4. Basic descriptives migration patterns

\begin{tabular}{|c|c|c|c|c|c|c|c|c|c|c|}
\hline & \multicolumn{5}{|c|}{ Angolans } & \multicolumn{5}{|c|}{ Nigerians } \\
\hline & $\mathrm{N}$ & Mean & SD & Min & Max & $\mathrm{N}$ & Mean & SD & Min & Max \\
\hline Number periods residence status & 305 & 2.92 & 0.56 & 1 & 6 & 296 & 2.22 & 0.72 & 1 & 5 \\
\hline Number periods work permits & 305 & 2.53 & 0.65 & 1 & 5 & 296 & 1.84 & 0.78 & 1 & 4 \\
\hline Number of years Netherlands & 305 & 13.77 & 4.25 & 0 & 24 & 295 & 8.33 & 5.85 & 0 & 32 \\
\hline
\end{tabular}

Source: TCRAf-Eu parent survey Netherlands, 2010-2011.

\subsubsection{Respondents' labour market participation}

As displayed in Table 3.5, most of the Angolans in the TCRAf-Eu sample are economically active ( 80 percent); most are employed full-time in skilled labour (69 percent). Few are studying ( 6 percent), few are homemakers ( 8 percent) and only 3 percent are currently unemployed. However, although most respondents are currently employed, most 
have experienced unemployment while in The Netherlands: 56 percent state that they have been unemployed in The Netherlands for a period of more than three months. The most-reported reason for those periods of unemployment is the lack of a working permit (43 percent) because asylum seekers are not allowed to work in The Netherlands. Only 2 respondents state that family responsibilities were the primary cause of their unemployment. As reported in section 3.3.1 the household net income of the Angolan respondents is quite high. As a consequence, 63 percent of the respondents report they have absolutely enough money for day-to-day expenses. Finally, few respondents had assets in Angola upon leaving Angola or at the moment of the interview. This could be the result of the fact that many left Angola during wartime and while very young.

As expected based on the numbers from the CBS, most of the Nigerian respondents are economically active and are employed full-time in skilled labour. However, 22 percent of the Nigerian sample was unemployed at the time of the survey, which is in stark contrast to the 3 unemployed Angolans in the TCRAf-Eu sample. The majority of the respondents have experienced unemployment in The Netherlands for more than three months (65 percent) (see Table 3.5). Most state that their unemployment was due to a lack of work permit (42 percent). Another reason often mentioned, and in line with interviews performed by van Heelsum and Thomas (2006), is language difficulties (20 percent). Finally, 12 percent cite family and child responsibilities as the reason for unemployment. Also important to note is that the majority of Nigerians report not having enough money for day-to-day expenses.

Table 3.5. Basic descriptives labour market participation

\begin{tabular}{|c|c|c|c|c|}
\hline & \multicolumn{2}{|c|}{ Angolans } & \multicolumn{2}{|c|}{ Nigerians } \\
\hline & $\mathrm{N}$ & $\%$ & $\mathrm{~N}$ & $\%$ \\
\hline \multicolumn{5}{|l|}{ Current activity } \\
\hline Economically active & 245 & 80.07 & 188 & 63.30 \\
\hline Studying & 17 & 5.56 & 21 & 7.07 \\
\hline Disabled & & & 1 & 0.34 \\
\hline Homemaker & 25 & 8.17 & 20 & 6.73 \\
\hline Unemployed & 9 & 2.94 & 65 & 21.89 \\
\hline Other & 10 & 3.27 & 2 & 0.67 \\
\hline Total & 306 & 100.00 & 297 & 100.00 \\
\hline \multicolumn{5}{|l|}{ Do you currently work? } \\
\hline Full-time & 162 & 66.67 & 128 & 71.11 \\
\hline Part-time & 77 & 31.69 & 37 & 20.56 \\
\hline Irregularly & 4 & 1.65 & 15 & 8.33 \\
\hline Total & 243 & 100.00 & 180 & 100.00 \\
\hline \multicolumn{5}{|c|}{ Wage earner: Type of employment } \\
\hline Unskilled employee & 43 & 18.07 & 52 & 34.90 \\
\hline
\end{tabular}




\begin{tabular}{|c|c|c|c|c|}
\hline & \multicolumn{2}{|c|}{ Angolans } & \multicolumn{2}{|c|}{ Nigerians } \\
\hline & $\mathrm{N}$ & $\%$ & $\mathrm{~N}$ & $\%$ \\
\hline Skilled employee & 169 & 71.01 & 68 & 45.64 \\
\hline Higher level occupation & 26 & 10.92 & 29 & 19.46 \\
\hline Total & 238 & 100.00 & 149 & 100.00 \\
\hline \multicolumn{5}{|c|}{ Ever been unemployed in The Netherlands for over 3 months? } \\
\hline Yes & 169 & 55.78 & 192 & 65.08 \\
\hline No & 134 & 44.22 & 103 & 34.92 \\
\hline Total & 303 & 100 & 295 & 100.00 \\
\hline \multicolumn{5}{|l|}{ Main reason for unemployment } \\
\hline Nothing available in own line of work & 25 & 14.62 & 26 & 13.54 \\
\hline Don't have needed skills/ experience & 16 & 9.36 & 1 & 0.52 \\
\hline Poor health, disability & 3 & 1.75 & 1 & 0.52 \\
\hline Language difficulties & 1 & 0.58 & 38 & 19.79 \\
\hline No papers & 27 & 15.79 & 82 & 42.71 \\
\hline Employers don't want to hire & 74 & 43.27 & 0 & 0 \\
\hline Family responsibility/ child responsibilities & 1 & 0.58 & 23 & 11.98 \\
\hline Educational qualifications not recognised & 2 & 1.17 & 10 & 5.21 \\
\hline Other & 4 & 2.34 & 10 & 5.21 \\
\hline Don't know & 18 & 10.53 & 1 & 0.52 \\
\hline Total & 171 & 100.00 & 192 & 100.00 \\
\hline \multicolumn{5}{|l|}{ Enough money for day to day expenses } \\
\hline Yes, absolutely & 190 & 63.12 & 147 & 49.49 \\
\hline No, not at all & 58 & 19.27 & 63 & 21.21 \\
\hline It depends & 53 & 17.61 & 87 & 29.29 \\
\hline Total & 301 & 100.00 & 297 & 100.00 \\
\hline
\end{tabular}

Source: TCRAf-Eu parent survey Netherlands. 2010-2011.

\subsection{Transnational family characteristics}

To fully understand the family dynamics in Angolan and Nigerian transnational families, we must know how transnational care is arranged, the identity of the parents in these transnational families and whether parents in transnational families are different from other Angolan or Nigerian families living in The Netherlands. For instance, are parents in transnational families distinguishable, in terms of socio-economic and demographic characteristics, from Angolan and Nigerian parents who live with their children in The Netherlands? Accordingly, in this section, I am going to look more closely at the conditions under which the transnational child raising arrangements in the data were formed and operate, giving special consideration to the specific context of 
migration and reception. This analysis provides me with information on the distinguishing features of parents in transnational families, enables me to contextualise the findings, and hints at important control variables for further analyses.

\subsubsection{Reasons for transnational separation}

The central focus in this section is the reasons parents give for transnational separation. Although I cannot be conclusive about the exact reasons for transnational family separation, I want to explore some of the reasons that migrant parents provided for their separation from their children.

To investigate the reasons for separation, we asked the respondents the main reason that they did not want their children living with them and, for parents who do prefer to have their children live with them, what is preventing the children from joining them. The largest proportion of the Angolan parents answered that the strict migration policies in place in The Netherlands kept their children from joining them (approximately 22 percent). Another often-cited reason for the separation is that the parent's (ex-) partner lives in Angola with the child or took the child when migrating back to Angola (approximately 15 percent). Approximately one-third of this group exists of partners or ex-partners who were deported from The Netherlands and took their children along. Other reasons mentioned include money issues ( 8 percent), getting to know the family in Angola or family requests (approximately 6 percent) and getting their children acquainted with the Angolan homeland (approximately 4 percent). Some children travelled to Angola for an extended period with one of their parents to get to know the country but will return to The Netherlands (approximately 8 percent). Finally, a few respondents lost contact with their children and do not know their whereabouts (approximately 6 percent). Reasons given by Angolan parents who do not want their children to live with them are diverse, but most mention that the child is doing well in Angola with the other biological parent. Some of these parents have separated from the other parent and have started new families in The Netherlands.

It is noteworthy that of the 395 Angolan children born in The Netherlands, 19 percent now live in Angola, and 39 percent of the children born in Angola currently live in The Netherlands. There are also parents whose children were born or have lived in The Netherlands, obtained Dutch nationality and then migrated to Angola, thus creating a different kind of transnational family. I found 60 cases of parent-child separation in which the child had first lived in The Netherlands and thereafter migrated to Angola, generally with the other biological parent. These are the parents who state that they want their children to get to know their families in Angola and their home country or whose children returned with the other parent who either wanted or was forced (deported) to return to Angola. Thus, the Angolan data contains a variety of family types, which came into being in different ways. As these families came into being in various ways and for various reasons, transnational families in which the child first lived in The 
Netherlands and thereafter moved to Angola are not treated as a separate group in the analyses. In addition, analyses conducted (not shown), indicate that the well-being of these parents is not significantly different than that of other transnational parents. Moreover, when taking into account length of separation (a control measure) parentchild relationships that are reported are also not significantly different. Therefore, although it is important to take the existence of this group into account when interpreting findings, I do not think it had a major effect on the findings reported.

Nigerian respondents who came to The Netherlands to study reported that children would distract them from their studies, which would not be beneficial for their families. Additionally, most of these respondents intend to go back to Nigeria once they finish their studies. Although many undocumented migrants in the TCRAf-Eu sample would love to be reunited with their children, it is legally and economically impossible to bring their children over. Even if they could bring their children over, they would not be able to attend school because they would have no documents, and the parents continue to see education as having great importance. Approximately 20 percent of the parents said it was very important for their children to finish school in Nigeria. A similar share of respondents mentioned that the Nigerian culture is better and that they do not want their children to grow up in the Dutch environment, where children are disrespectful and opportunities are limited. One respondent answered that she does not want her daughter to come to The Netherlands because that would mean that her daughter would suffer like she does. Another respondent stated, "My children are too educated to clean houses in The Netherlands". Finally, we see that only 31 percent of the transnational parents want to stay in The Netherlands: the majority want to return to Nigeria. This is in stark contrast to Angolans: 80 percent of the Angolan transnational parents want to stay in The Netherlands and only 20 percent want to return to Angola. Thus, it seems that Nigerian transnational parents eventually want to return to Nigeria and want their children to remain in Nigeria so that they finish school and are not exposed to the negative aspects of Dutch culture. Conversely, the majority of Angolan transnational parents want to stay in The Netherlands and want their children to join them. However, because some children migrated with the other biological parent to Angola, reunification in The Netherlands is not always possible.

One reason for separation that became apparent is that the parents are divorced/ separated and the other parent remained in or returned to the country of origin. Some studies suggest that union dissolution can trigger migration (Frank \& Wildsmith, 2005; Hill, 2004; Pribilsky, 2004), although evidence is mixed. A different line of research suggests that divorced parents, especially fathers, have a worse relationship with their children (Amato \& Booth, 1996). Thus, the functioning of transnational child raising arrangements could be different in transnational families in which the parents are separated or divorced. Indeed, Nobles (2011) finds that migrant fathers are much more involved in the care of their children back home if they remain married to the mother 
caring the children in the country of origin, who is more likely than an ex-wife to facilitate the relationship between the migrant father and his children. Thus, it is important to consider the issue of divorce when researching transnational families because it not only can create transnational family life but also can affect the functioning of arrangements already in place.

Table 3.6 displays whether of the children part of the data parents are divorced/ separated, and compares this for transnational and non-transnational children. When reading this table, one must remember that some of these children are linked to the same parent. In the data, most of the respondents remain with their children's other biological parent: the parents of approximately 62 percent of the Angolan children and 71 percent of the Nigerian children are still in a relationship or are married. However, if I distinguish between transnational and non-transnational parents, I find significant differences. Whereas 30 percent of the Angolan and 18 percent of the Nigerian parents of non-transnational children are separated, this share is much larger for the parents of transnational children: approximately 46 percent for both groups. We must remember, however, that Table 3.6 displays all children, some of whom have the same parent. Additionally, it is important to note that in comparison to Nigerians, Angolans are more likely to have children with different partners. In sum, in transnational families, the children's biological parents are more often divorced or separated. Therefore, one of the reasons for transnational parent-child separation could be the parents' separation or divorce. As indicated by Nobles (2011), this can have consequences for the functioning of transnational child raising arrangements, which I will explore in the next chapter.

Table 3.6. Parents child separated / divorced by transnational children

\begin{tabular}{|c|c|c|c|c|c|c|}
\hline & \multicolumn{3}{|l|}{ Angolans } & \multicolumn{3}{|l|}{ Nigerians } \\
\hline & $\begin{array}{l}\text { Transn. } \\
\text { child }\end{array}$ & $\begin{array}{l}\text { Non-transn. } \\
\text { child }\end{array}$ & $\mathrm{N}(\%)$ & $\begin{array}{l}\text { Transn. } \\
\text { child }\end{array}$ & $\begin{array}{l}\text { Non-transn. } \\
\text { child }\end{array}$ & $\mathrm{N}(\%)$ \\
\hline Parents no longer together & $96(53.93)$ & $114(29.46)^{\star \star \star *}$ & $210(37.17)$ & $103(46.82)$ & $63(17.75)^{\star \star \star \star}$ & $166(28.87)$ \\
\hline Parents together & $82(46.07)$ & $273(70.54)^{* * *}$ & $355(62.83)$ & $117(53.18)$ & $292(82.25)^{\star * *}$ & $409(71.13)$ \\
\hline Total & $178(100)$ & $387(100)$ & $570(100)$ & $220(100)$ & $355(100)$ & $575(100)$ \\
\hline
\end{tabular}

Source: TCRAf-Eu parent survey Netherlands, 2010-2011.

Notes: Pearson's chi-square reported. Tests at the parent level provide similar results. Trans child refers to transnational child and non-trans child refers to non-transnational child.

${ }^{*} \mathrm{p}<0.05 ;{ }^{* *} \mathrm{p}<0.01 ;{ }^{* *} \mathrm{p}<0.001$.

In conclusion, there are multiple factors that can cause the formation of transnational families that differ from the types of transnational families typically mentioned in the literature in which one parent migrates to provide for the family. First, and as typically described in the literature, some respondents do not have the right papers or enough money to bring their children and possible partners over. Second, Nigerian parents in particular do not want their children to be exposed to Dutch culture and prefer Nigerian 
culture and schooling for their children. Third, transnational families come into being when parents separate and one of the parents remains or decides to live in the country of origin, whereas the other parent wants to stay in The Netherlands. Finally, a finding that is unique to Angolans is that some children migrate to Angola after having lived in The Netherlands: some Angolan children's stays in The Netherlands are only temporary. The fact that Angolans came as asylum seekers to The Netherlands seems to have an impact on the formation of transnational families. On the one hand, this made it easier for those families to come to The Netherlands (with their children) and to obtain Dutch nationality. Therefore, it has been easier for children and parents to travel between Angola and The Netherlands, thereby enabling different types of transnational child raising arrangements. On the other hand, for (ex-) partners of respondents who did not obtain Dutch nationality, this has resulted in their need to return to Angola, either with or without their children. Notably, in the reasons mentioned for family separation, no parent mentioned the war, although a few respondents did lose contact with their children during the war and do not know their whereabouts. The fact that many Angolan asylum seekers came to The Netherlands at very young ages also means that many did not have children upon entry, which affects the results.

\subsubsection{Parenting across borders}

In this section, I will investigate how transnational child raising is arranged. First, it is important to know the caregiver of the children in the country of origin. From Table 3.7, we can conclude that most of the children in the TCRAf-Eu sample are cared for by kin, usually the 'other' biological parent. Interestingly, for the male respondents it is often the ex-wife or the wife or mother who cares for the child in Nigeria, whereas for the female respondents somebody in the matrilineal clan, not the father, often cares for the children. Of the children living in Angola, 64 percent are cared for by their mother and 13 percent by their father. For Nigerian children the numbers are 62 and 6 percent respectively. Other caregivers are primarily matrilineal and female. Most of these caregivers are in their thirties (like the respondents themselves) and are employed. The majority of the respondents state that the choice to use the mother as the caregiver is because it is natural for a mother to care for the child: she gave birth to the child and has been the child's primary caregiver ever since. Additionally, these fathers state that the child feels closest to her. When grandmothers are caregivers, the respondents indicate that they chose her because their mother is the one who they trust most. Another reason particular to Angolans, and mentioned for 16 children, is that one parent, or both the parent and the children, were deported or forced to move and therefore left the country. Finally, as mentioned in the previous section, at times the family in Angola wants to see the children for an extended period of time and therefore the children reside temporarily with them. Some fathers' children were born outside of their relationship or marriage and therefore stayed with their mothers in Angola. 
Mostly, as displayed in Table 3.7, the respondents are in contact with the caregiver and their children at least once a week, although Nigerians are in contact significantly more often than Angolans. Approximately 25 percent of the Angolan parents have contact with the caregiver/child once or twice a month, whereas 9 percent for Nigerians have that level of contact. Although contact was lost with four Nigerian children, 15 Angolan children have no contact with their migrant parent. Furthermore, the respondents predominantly report a good relationship with their children and therefore are very satisfied with that relationship. Additionally, most of the respondents report a good relationship with the caregivers: most do not have or hardly ever have serious arguments with their caregivers and are very satisfied with the care provided to their children. However, again I find differences between Angolans and Nigerians. Angolans are significantly less satisfied with their caregivers and more often report a poor relationship with their children and the caregiver. Some of the reasons given for dissatisfaction with care are that the caregivers are not strict enough or do not provide good care, do not have time for the children, ask for money and do not contact the parent. When the transnational parents have serious arguments with the caregiver, they are usually about money issues and the children's education.

In general, transnational parent-child separation does not seem to have a major impact on the relationship these parents have with their children because most report to a good relation with their child. However, when I compare the relationships parents report with their children in The Netherlands to the relationships with their transnational children, I do find significant differences. To investigate those differences, I have created a dummy variable of parents' relationship with their children. The first category contains the children of parents who reported having an always and often open/warm relationship with and the other category the children who they usually, sometimes or never have an open/warm relationship with. The results are displayed in Table 3.8. I have also performed this test at the parent level, where I compare parents who do not have an open/warm relationship with at least one child to parents who report good relationships with all of their children. The results found are similar.

I find that for both Angolans and Nigerians, a poor relationship is significantly more often reported for children in the home countries than for children living in The Netherlands. 11 and 6 percent of the non-transnational children, respectively, are reported to have a poor relationship with the parent, whereas 39 and 19 percent of the transnational children, respectively, have a poor relationship with the parent. It thus seems that although most parents are satisfied with the care provided and their overall relationships with their children and caregivers, transnational parenting does have an impact on the relationships maintained by parents and children across borders. 
Table 3.7. Descriptive statistics relation caregiver and child

\begin{tabular}{|c|c|c|c|c|}
\hline & \multicolumn{2}{|c|}{ Angolans } & \multicolumn{2}{|c|}{ Nigerians } \\
\hline & $\mathrm{N}$ & $\%$ & $\mathrm{~N}$ & $\%$ \\
\hline \multicolumn{5}{|c|}{ Relationship child as reported by respondent } \\
\hline Always open/warm & 75 & 44.91 & 129 & 58.64 \\
\hline Often open/warm & 27 & 16.17 & 56 & 25.45 \\
\hline Usually open/ warm & 46 & 27.54 & 23 & 10.45 \\
\hline Sometimes open/warm & 5 & 2.99 & 11 & 5 \\
\hline Hardly ever open/warm & 5 & 2.99 & 0 & 0 \\
\hline Never open/warm & 9 & 5.39 & 1 & 0.45 \\
\hline Total & 167 & 100 & 220 & 100 \\
\hline \multicolumn{5}{|c|}{ In the past month how often respondent in contact with child? } \\
\hline Everyday & 45 & 26.01 & 42 & 19 \\
\hline Few times a week & 34 & 19.65 & 111 & 50.23 \\
\hline Once a week & 38 & 21.97 & 49 & 22.17 \\
\hline Once or twice a month & 41 & 23.70 & 17 & 7.69 \\
\hline Not at all & 15 & 8.67 & 2 & 0.9 \\
\hline Total & 173 & 100 & 221 & 100 \\
\hline \multicolumn{5}{|l|}{ Caregiver of child - lineage } \\
\hline Mother & 111 & 63.79 & 136 & 61.54 \\
\hline Father & 23 & 13.22 & 13 & 5.88 \\
\hline Matrilineal relative & 28 & 16.09 & 44 & 19.91 \\
\hline Patrilineal relative & 6 & 3.45 & 21 & 9.5 \\
\hline Siblings & 0 & 0 & 4 & 1.81 \\
\hline Non kin & 0 & 0 & 2 & 0.9 \\
\hline Nobody & 2 & 1.15 & 1 & 0.45 \\
\hline Do not know & 4 & 2.30 & 0 & 0 \\
\hline Total & 174 & 100 & 221 & 100 \\
\hline \multicolumn{5}{|l|}{ Sex of caregiver child } \\
\hline Female & 142 & 83.53 & 203 & 92.27 \\
\hline Male & 28 & 16.47 & 17 & 7.73 \\
\hline Total & 170 & 100 & 220 & 100 \\
\hline \multicolumn{5}{|c|}{ Relationship with caregiver of child } \\
\hline Always open/warm & 78 & 46.99 & 134 & 63.21 \\
\hline Often open/warm & 28 & 16.87 & 34 & 16.04 \\
\hline Usually open/ warm & 38 & 22.89 & 29 & 13.68 \\
\hline Sometimes open/warm & 6 & 3.61 & 8 & 3.77 \\
\hline Hardly ever open/warm & 3 & 1.81 & 6 & 2.83 \\
\hline Never open/warm & 13 & 7.83 & 1 & 0.47 \\
\hline Total & 166 & 100 & 212 & 100 \\
\hline \multicolumn{5}{|c|}{ Frequency of contact with caregiver of child } \\
\hline Everyday & 42 & 25.15 & 48 & 22.43 \\
\hline Few times a week & 50 & 29.94 & 101 & 47.2 \\
\hline Once a week & 17 & 10.18 & 37 & 17.29 \\
\hline Once or twice a month & 44 & 26.35 & 24 & 11.21 \\
\hline Not at all & 14 & 8.38 & 4 & 1.87 \\
\hline Total & 167 & 100 & 214 & 100 \\
\hline \multicolumn{5}{|c|}{ Satisfaction with caregiver child } \\
\hline Very satisfied & 82 & 49.70 & 131 & 61.21 \\
\hline Satisfied & 34 & 20.61 & 58 & 27.0 \\
\hline
\end{tabular}




\begin{tabular}{lrrrrrr}
\hline & \multicolumn{2}{c}{ Angolans } & & \multicolumn{2}{c}{ Nigerians } \\
\cline { 3 - 4 } \cline { 6 - 7 } & \multicolumn{1}{c}{ N } & $\%$ & & $\mathrm{~N}$ & $\%$ \\
\hline Neutral & 25 & 15.15 & & 20 & 9.35 \\
Not so satisfied & 7 & 4.24 & & 5 & 2.34 \\
Very dissatisfied & 17 & 10.30 & & 0 & 0 \\
Total & 165 & 100 & & 214 & 100 \\
\hline
\end{tabular}

Source: TCRAf-Eu parent survey Netherlands, 2010-2011.

Notes: This table reflects all transnational children/caregivers the parents report on. Therefore some of these children/caregivers are linked to the same parent. Also, due to missing values the total $\mathrm{N}$ is different per variable.

Table 3.8. Parent-child relationship by transnational children

\begin{tabular}{|c|c|c|c|c|c|c|}
\hline & \multicolumn{3}{|l|}{ Angolans } & \multicolumn{3}{|l|}{ Nigerians } \\
\hline & Trans. child & Non-trans child & $\mathrm{N}(\%)$ & Trans child & Non-trans child & $\mathrm{N}(\%)$ \\
\hline Good relationship & $102(61.08)$ & $358(93.69)^{* * *}$ & $460(83.94)$ & $185(84.09)$ & $336(94.92)^{* * *}$ & $521(90.77)$ \\
\hline Poor relationship & $65(38.92)$ & $23(6.04)^{\star * *}$ & $88(16.06)$ & $35(15.91)$ & $18(5.08)^{\star * *}$ & $53(9.23)$ \\
\hline Total & $167(100)$ & $381(100)$ & $548(100)$ & $220(100)$ & $354(100)$ & $574(100)$ \\
\hline
\end{tabular}

Source: TCRAf-Eu parent survey Netherlands, 2010-2011.

Notes: Pearson's chi-square reported. Tests at the parent level provide similar results. Trans child refers to transnational child and non-trans child refers to non-transnational child.

${ }^{*} \mathrm{p}<0.05 ;{ }^{* *} \mathrm{p}<0.01 ;{ }^{* * *} \mathrm{p}<0.001$.

\subsubsection{Comparing transnational parents with non-transnational parents}

In this section, I will look into observable demographic and socio-economic differences between transnational and non-transnational parents. First, I find that although I tried to sample an equal number of men and women in both categories, there are more transnational fathers than mothers in the data (see Table 3.9). When recruiting respondents, it proved more difficult to find transnational mothers than transnational fathers. This might indicate that it is more common for fathers to be internationally separated from their children than it is for mothers. Furthermore, I find that in both migrant groups, there are no significant differences in marital status when comparing transnational and non-transnational parents. However, I do find that Angolan women, whether in a transnational family or not, more often report that they are single (21 percent of the transnational and 31 percent of the non-transnational group as opposed to 6 and 12 percent of transnational and non-transnational men, respectively). Men also are more likely than women to report to being in a relationship.

T-tests further indicate that Nigerian non-transnational parents have been in The Netherlands for a longer period of time than have transnational Nigerian parents, with a mean of 6.11 as opposed to 4.49 . This could indicate that Nigerian parents and children will eventually be reunited in The Netherlands. However, for the Angolan parents, I find no difference related to the number of years the respondent has been in The Netherlands. This is because most Angolans, both transnational and non-transnational, came 
Table 3.9. Cross-tabulations socio-demographic characteristics and transnational parent

\begin{tabular}{|c|c|c|c|c|c|c|}
\hline & \multicolumn{3}{|l|}{ Angolans } & \multicolumn{3}{|l|}{ Nigerians } \\
\hline & Trans. & Non-trans. & $\mathrm{N}(\%)$ & Trans. & Non-Trans. & $\mathrm{N}(\%)$ \\
\hline \multicolumn{7}{|l|}{ Sex (\%) } \\
\hline Female & 30.22 & $62.28^{\star * *}$ & $146(47.71)$ & 28.79 & $51.52^{\star * *}$ & $123(41.41)$ \\
\hline Male & 69.78 & $37.72^{\star * *}$ & $160(52.29)$ & 71.21 & $48.48^{\star * *}$ & $174(58.59)$ \\
\hline \multicolumn{7}{|l|}{ Marital status (\%) } \\
\hline Single & 17.99 & 15.66 & $51(16.72)$ & 15.10 & 12.73 & $42(14.14)$ \\
\hline Relationship & 35.97 & 38.55 & $114(37.38)$ & 18.94 & 13.33 & $47(15.82)$ \\
\hline Married & 46.04 & 45.78 & $140(45.90)$ & 65.15 & 73.94 & $208(70.03)$ \\
\hline \multicolumn{7}{|l|}{ Legal status (\%) } \\
\hline Documented & 98.56 & 99.40 & $302(99.02)$ & 75.52 & $92.73^{\star * *}$ & $248(83.78)$ \\
\hline Undocumented & 1.44 & 0.60 & $3(0.98)$ & 27.48 & $7.27^{\star * *}$ & $48(16.22)$ \\
\hline \multicolumn{7}{|l|}{ Household income (\%) } \\
\hline Less than $€ 500$ & 1.46 & 3.09 & $7(2.34)$ & 30.48 & $7.35^{* * *}$ & $42(17.43)$ \\
\hline$€ 500-1000$ & 5.84 & $15.00^{*}$ & $32(10.70)$ & 21.90 & $7.35^{\star *}$ & $33(13.69)$ \\
\hline$€ 1000-1500$ & 27.01 & 32.10 & $89(29.77)$ & 20.95 & 22.79 & $53(21.99)$ \\
\hline$€ 1500-2000$ & 56.93 & $40.00^{* *}$ & $143(47.83)$ & 17.14 & 15.44 & $39(16.18)$ \\
\hline More than $€ 2000$ & 8.76 & 16.00 & $28(9.36)$ & 9.52 & $47.06^{* * *}$ & $74(30.71)$ \\
\hline \multicolumn{7}{|c|}{ Enough money to live on day-to-day? (\%) } \\
\hline Yes, absolutely & 62.77 & 63.41 & $190(63.12)$ & 33.33 & $62.42^{* * *}$ & $147(49.49)$ \\
\hline No, not at all & 21.9 & 17.07 & $58(19.27)$ & 31.82 & $12.73^{*}$ & $36(21.21)$ \\
\hline It depends & 15.33 & 19.51 & $53(17.610$ & 34.85 & $24.85^{\star}$ & $87(29.29)$ \\
\hline \multicolumn{7}{|l|}{ Housing (\%) } \\
\hline Apartment & 42.45 & 39.52 & $125(40.85)$ & 46.97 & $70.30^{* * *}$ & $178(59.93)$ \\
\hline House & 38.13 & $56.29^{\star *}$ & $147(48.04)$ & 9.09 & $24.84^{\star * *}$ & $53(17.85)$ \\
\hline Renting a room & 17.99 & $1.80^{* * *}$ & $25(17.99)$ & 28.79 & $4.24^{\star * \star}$ & $45(15.15)$ \\
\hline Other & 1.44 & 2.40 & $6(1.96)$ & 15.15 & $0.61^{\star * *}$ & $21(7.07)$ \\
\hline \multicolumn{7}{|l|}{ Type of employment } \\
\hline Unskilled labour & 18.03 & 18.10 & $43(18.07)$ & 45.61 & $28.26^{\star}$ & $52(34.90)$ \\
\hline Skilled labour & 74.59 & 67.24 & $169(71.01)$ & 45.61 & 45.65 & $68(45.64)$ \\
\hline Higher level & 7.38 & 14.66 & $26(10.92)$ & 8.77 & $26.09^{\star *}$ & $29(19.46)$ \\
\hline \multicolumn{7}{|c|}{$\begin{array}{l}\text { Been unemployed in NL more } \\
\text { than } 3 \text { months }\end{array}$} \\
\hline No & 34.31 & $52.41^{* *}$ & $134(44.22)$ & 25.19 & $42.68^{* *}$ & $103(34.92)$ \\
\hline Yes & 65.69 & $47.59^{\star \star}$ & $169(55.78)$ & 74.81 & $57.32^{\star *}$ & $192(65.08)$ \\
\hline \multicolumn{7}{|l|}{ Current activity status } \\
\hline Economically active & 90.65 & $71.26^{* * *}$ & $245(80.07)$ & 53.03 & $71.52^{\star *}$ & $188(63.30)$ \\
\hline Studying & 1.44 & $9.00^{* *}$ & $17(5.56)$ & 12.88 & $2.42^{* * *}$ & $21(7.07)$ \\
\hline Homemaker & 1.44 & $13.77^{\star * *}$ & $25(8.17)$ & 5.30 & 7.88 & $20(6.73)$ \\
\hline Unemployed & 5.04 & $1.20^{*}$ & $9(2.94)$ & 27.27 & $17.58^{*}$ & $65(21.89)$ \\
\hline Other & 1.44 & 4.79 & $10(3.27)$ & 1.52 & 0.61 & $3(1.01)$ \\
\hline \multicolumn{7}{|c|}{ Continuous variables (Mean $(s d)$ ) } \\
\hline Years in the Netherlands & $13.8(4.5)$ & $13.8(4.1)$ & $13.8(4.3)$ & $6.4(4.5)$ & $10.2(6.1)^{\star * *}$ & 8.35 \\
\hline Number of friends NL & $24.5(36.8)$ & $34.4(39.6)^{*}$ & $29.9(38.6)$ & $15.5(25.3)$ & $13.8(25.4)$ & $14.7(25.3)$ \\
\hline Number of family NL & $5.7(10.9)$ & $5.0(12.9)$ & $5.3(12)$ & $0.7(1.54)$ & $1.5(2.9)^{\star *}$ & $1.19(2.4)$ \\
\hline
\end{tabular}

Source: TCRAf-Eu parent survey Netherlands, 2010-2011.

Notes: Differences between transnational parents and non-transnational parents tested with Pearson's chisquare test for categorical and t-test for continuous variables. Trans refers to transnational and non-trans refers to non-transnational. ${ }^{\star} \mathrm{p}<0.05 ;{ }^{* *} \mathrm{p}<0.01 ;{ }^{* *} \mathrm{p}<0.001$. 
as asylum seekers during the war period (which lasted until 2002), when obtaining a Dutch visa was relatively easy. Furthermore, amongst the Nigerians, the largest share of undocumented migrants is found amongst transnational parents, and this difference is significant. Because in the Angolan sample only 3 respondents indicated that they were undocumented, I did not study this group's legal status. In addition, I find that Angolan non-transnational parents report having more friends living in The Netherlands and Nigerian non-transnational parents report having more family living in The Netherlands.

Next, I find that there are significant differences in the socio-economic status of transnational and non-transnational parents. However, there are important dissimilarities between the migrant groups. I find that Nigerian non-transnational parents more often report that they are certain to have money for day-to-day expenses in comparison to transnational parents who report more often that they sometimes or always do not have enough money. No such differences are found for Angolans. In addition, Nigerian transnational parents are more often found at the lower income levels (€500-1000 per month) and less often at the higher income levels (over €2000 per month), whereas Angolan transnational parents are more often found at the medium income levels (€1500-2000) and less often at the lower income levels (€500-1000 per month). The latter is an unexpected finding. However, looking at another indicator of wealth, home ownership, I find that non-transnational parents more often live in a house, whereas transnational parents more often rent a room. The same applies to Nigerians.

Looking at the labour market position of transnational parents, I find that in both groups, there are significant differences between transnational and non-transnational parents. One striking finding is that amongst both groups, transnational parents are more often unemployed. Although in the Angolan sample this number is small, 18 percent of the Nigerian transnational parents were unemployed at the time of the survey. We also see this statistic reflected in a measure that asked whether the respondent has been unemployed while living in The Netherlands and seeking for work for a period of over three months: more transnational parents have experienced this. Other findings are different for the two migrant groups. For example, in the Angolan sample more transnational than non-transnational parents are economically active, while for Nigerians the reverse is found. Finally, I find more Nigerian transnational than non-transnational parents are found in unskilled labour and fewer Nigerian transnational than nontransnational parents are found in highly skilled occupations.

To conclude, the results displayed in Table 3.9 tell a mixed story. On the one hand, I find that wealth in terms of income is greater for Angolan transnational parents and for Nigerian non-transnational parents. If I measure wealth in terms of house ownership in The Netherlands, non-transnational parents are wealthier in both groups. This could be the result of transnational parents investing less in the host country or the fact that in The Netherlands, non-transnational parents live with their children and thus require 
better housing. Moreover, I find in general that Nigerian transnational parents have lower socio-economic status no matter how it is measured. Additionally, in terms of their labour market position, Nigerian transnational parents seem to be the most affected. These findings could be the result of the fact that most Angolans arriving in The Netherlands were received in the same manner and received the same opportunities due to the asylum policies that applied to them and because of their refugee status. On the other hand, the differences between Nigerian transnational and non-transnational parents that I find seem to indicate that Nigerian transnational parents are in a more precarious position. These conditions might be the reason that these parents are in transnational families. A condition for family reunification is legal status and a stable income at a particular level, which we can see that these parents do not always have. Additionally, most of the factors investigated are intrinsically related.

\subsection{Conclusion}

Most transnational parents prefer their children to live with them in The Netherlands. Some respondents mention that the reason for transnational separation is that they cannot successfully complete legal procedures for which a certain and stable income and legal documents are required. Other reasons given for separation are preferences for their children to grow up in their own culture and communities in the presence of extended family and for their children to receive appropriate schooling. Some transnational separations also occur after parental separation or divorce in which one parent migrates while the other remains in the country of origin.

Caregivers are mostly female kin, usually the child's other biological parent. Parents generally report having good relationships with both their children and their caregivers. However, I find that the relationships parents reported to have with their children in The Netherlands are significantly better. Thus, transnational family life does seem to have an impact on family relationships. Descriptive statistics showed an important difference between Angolans and Nigerians. Angolans are less often in contact with their children and caregivers than are Nigerians. This might have an impact on parentchild relationships and on the subjective well-being of Angolan parents, which I will investigate in the coming chapters.

By investigating differences between transnational and non-transnational parents, I found that transnational parents are to be differentiated from non-transnational parents in terms of their socio-economic status, legal status and labour market position. However, most of these differences are found in the Nigerian sample. Nigerian transnational parents are found to have significantly lower socio-economic status in terms of housing and income, and they report significantly more often that they do not have enough money for their day-to-day expenses. In addition, Nigerian transnational parents have been and (at the time of the interview) are more often unemployed and more often 
found in unskilled labour. Finally, these parents more often are undocumented and have a smaller number of family members living in The Netherlands. Angolan transnational parents are more likely to have been unemployed, but at the time of interview are more often economically active and are found more often in higher income categories. Additionally, Angolan transnational parents have a smaller social network in terms of having friends in The Netherlands. The finding that few differences are found in the Angolan sample could be because both transnational and non-transnational parents came to The Netherlands under the same circumstances-fleeing the war and seeking asylum-and thus were provided with the same opportunities in The Netherlands. Additionally, Angolans' reasons for transnational family separation are different from those of Nigerians: some Angolan children lived in The Netherlands before migrating to Angola.

In conclusion, this chapter has shown that there are important differences between transnational and non-transnational families and Angolans and Nigerians that must be considered when investigating the effects of transnational family life in the following chapters. These include socio-economic and legal status, social networks, labour market position, parent-child relationships and, particularly when investigating transnational families, the amount of contact with the child. 


\section{CHAPTER 4.}

\section{Quality of parent-child relationships in transnational families}

This chapter has been published as Haagsman, K., \& Mazzucato, V. (2014). The Quality of Parent-Child Relationships in Transnational Families: Angolan and Nigerian Migrant Parents in The Netherlands. Journal of Ethnic and Migration Studies, 40 (11), 1677-1696. 



\subsection{Introduction}

One of the main effects of global migration is the change it brings to the families involved, particularly when families are dispersed across the globe (Bryceson \& Vuorela, 2002; Parreñas, 2005; Zontini, 2004). The resulting transnational families are families whose members reside in different countries and whose kinship ties consequently extend across national borders. This situation can result, for example, from parents who migrate and leave their children in the country of origin to be cared for by someone else, which is the focus of this study. A growing body of research indicates that although new technologies have made it easier to communicate with kin in home countries, it can be challenging to maintain intimate relationships across borders (Banfi \& Boccagni, 2011; Bernhard et al., 2009; Parreñas, 2005; Pribilsky, 2004).

The formation and functioning of transnational families is not homogenous and is affected by social, economic, and geographical inequalities (Bryceson \& Vuorela, 2002; Fresnoza-Flot, 2009; Parreñas, 2005; Schmalzbauer, 2004). The literature indicates the importance of gender norms (Dreby, 2006; Parreñas, 2005; Pribilsky, 2004), immigration policies (Falicov, 2007; Fresnoza-Flot, 2009; Menjívar, 2012), class position (Dreby \& Adkins, 2010; Parreñas, 2005; Schmalzbauer, 2008), and means of communication (Fedyuk, 2012; Madianou \& Miller, 2011; Parreñas, 2005). Additional factors include the way that remittances are sent, the length of separation, the child's age when separated, and the relationship the parent retains with the caregiver in the country of origin (Carling et al., 2012; Fresnoza-Flot, 2009; Pribilsky, 2004; Schmalzbauer, 2008). Most of these studies are qualitative case studies that have focussed on only one or a few of these factors simultaneously. Some quantitative studies have examined transnational families, but these studies have mainly focused on children in the country of origin (for a review see Mazzucato, 2013a). This type of research is scarce for migrant parents.

This study contributes to the burgeoning literature on transnational family life by specifically investigating how different characteristics of family arrangements are associated with migrant parents' perceptions of the quality of the transnational parent-child relationship. We analyse quantitative data collected for this purpose, with which we are able to investigate the relationship between specific transnational family characteristics and the relationships parents maintain with their children. In so doing, we systematically and simultaneously explore factors that have been identified but not fully explored in the qualitative literature while controlling for important basic demographic characteristics.

This study draws on survey data collected amongst Nigerian and Angolan migrant parents in The Netherlands. The comparison of two migration flows allows us to address two further gaps in the literature. First, transnational family literature has seldom focussed on sub-Saharan countries of origin and European countries of destination. Second, the experiences of migrant parents in transnational families are not only shaped 
by individual circumstances, such as the social and economic characteristics of the migrant, but also by factors at the macro level, such as the conditions in the country of origin and the migration regimes in the country of destination (Åkesson, Carling, \& Drotbohm, 2012). Most research on transnational families has been based on single migratory flows, examining one country of origin and one country of destination (Levitt \& Jaworsky, 2007; Mazzucato \& Schans, 2011). Studying two African flows that are characterized by different conditions at origin and at reception in The Netherlands, allows us to explore how macro-level conditions influence the way relationships between migrant parents and their children in the home country take shape. Angolans immigrated to The Netherlands due to civil strife whereas Nigerians migrated predominantly for economic reasons. Consequently, Angolans and Nigerians face different migration regimes in The Netherlands: Angolans have mainly entered as asylum seekers and Nigerians as labour migrants.

The paper is structured as follows. Section one provides a literature overview and identifies five factors of importance for transnational parent-child relationships. Section two briefly discusses the history of migration to The Netherlands by Angolan and Nigerian migrant groups. The third section discusses the data and methods of analyses. Section four discusses the results of the analyses performed. The last section concludes.

\subsection{Literature review}

Five factors that influence the transnational parent-child relationship can be identified in the transnational family literature. We argue that although these factors are mentioned by previous studies, they have not been analysed simultaneously and they have not been compared systematically across different groups. In this section, we discuss each of these factors.

\subsubsection{Gender}

The most commonly discussed characteristic in transnational family literature is the role of maternal migration. Research on migrant women has stressed the role these mothers traditionally hold as the main and most important caregiver of the child and hence the way that separation produces new meanings of motherhood. Migrant mothers attempt to maintain a close relationship with their children while struggling with the redefinition of their parenting role. Migrant fathers have remained relatively under-researched (Poeze \& Mazzucato, 2012; Pribilsky, 2004; Waters, 2009). Furthermore, when men are mentioned, it is often not in a positive manner. Men are considered to show little concern for the well-being of their children and to neglect their care responsibilities. Waters states that a reason for this negative picture of migrant men might be the fact 
that they are rarely the object of study themselves but "are examined only to the extent that they impact on women's lives" (Waters, 2009, p. 66).

Several differences between men and women can be identified. First, the literature shows that although both mothers and fathers are expected to provide economically for their children, mothers are additionally expected to provide emotional care (Hondagneu-Sotelo \& Avila, 1997; Parreñas, 2005). This expectation is a result of gender ideologies in which women are responsible for reproductive care work and are in charge of the practicalities of everyday life. Children are reported as perceiving their mothers as their primary caregivers and as central to the family, whereas their fathers' role is seen as peripheral. Consequently, some studies suggest that children in the country of origin miss their mothers to a greater extent than their fathers and reproach their mothers more often for leaving them behind (Parreñas, 2005).

These traditional gender ideologies shape the experiences not only of the children in the country of origin but also of migrant parents (Dreby, 2006). The literature suggests that migrant fathers are less involved in the care of their children in the home country than migrant mothers (Parreñas, 2008). Dreby (2006) concludes that the main difference between Mexican migrant fathers and mothers is the expectations of them by the family back home and the responses of the parents to these expectations. Dreby found that if fathers cannot fulfil their children's financial expectations, they feel that they are bad fathers and, consequently, grow distant from their children. In contrast, for migrant mothers, emotional care work is of primary importance. Consequently, mothers feel guiltier than fathers do for leaving their children behind because they are unable to provide the emotional care expected of them. The emotional toll on mothers has been reported to lead to ill health (see also Horton, 2009; Schmalzbauer, 2004). Therefore, we anticipate that gender will play a significant role in how migrant parents perceive their relationships with their children at home.

\subsubsection{The amount of contact and remittances}

Maintaining regular contact with family members back home and sending remittances are of crucial importance for maintaining intimate family ties. One of the main ways a migrant parent can remain involved in the care of his or her children in the home country and can engage in transnational parenting is by regularly communicating with the caregiver and the children. The literature stresses that in this way, a parent is socially and emotionally present and can obtain intimacy while being physically absent. Hence, this communication is important for maintaining the parent-child relationship (Parreñas, 2005; Zentgraf \& Chinchilla, 2012). Frequency and regularity of contact are mentioned as being more important than the information that is shared because this contact serves as a confirmation of the family bond and provides a sense of coherence (Carling et al., 2012; Madianou \& Miller, 2011). Through contact, the parent and child can stay emotionally involved, and the guilt parents feel can be reduced. Furthermore, contact 
reduces the emotional gap between parents and children because little or infrequent contact can be interpreted by a child as disinterest or abandonment (Suarez-Orozco et al., 2002; Zentgraf \& Chinchilla, 2012).

Although regular contact is the 'glue that keeps transnational families together' (Zentgraf \& Chinchilla, 2012, p. 351), 'remittances [...] are the currency of contact across borders' (Dreby \& Adkins, 2010, p. 680). The improvement of the economic situation in the home country is one of the main reasons for parents to migrate. Migrant parents are able to address the pain of separation from their children through the material gains their migration provides for the family (Schmalzbauer, 2008; Wong, 2006). The ability to send remittances gives migrant parents the feeling that they are fulfilling their roles as parents and makes them feel involved in the care of their children (Fresnoza-Flot, 2009; Parreñas, 2005; Zentgraf \& Chinchilla, 2012). Conversely, a decline or lack of remittances may damage the relationship between the migrant parent and the caregiver (Carling et al., 2012; Pribilsky, 2004) as well as between the migrant parent and the child (Dreby, 2006).

\subsubsection{The caregiver}

The care provided to the child is of high importance for the well-being of both the migrant parent and the child. Caregivers are important for mediating the relationship between a migrant parent and a child. Especially in child-related crises, such as illness of the child, parents may feel powerless (Mazzucato, 2011). The presence of a good and trustworthy caregiver at home can ease a migrant parent's burden in such cases. Furthermore, a caregiver can help a child see his or her parent's migration in a positive light by stressing the migrant parent's sacrifice of migrating for the child's good. Consequently, the child may be more likely to maintain a good image of the migrant parent (Schmalzbauer, 2008; Suarez-Orozco et al., 2002). A lack of good childcare can affect the relationship between parents and children as children may reproach their parents for leaving them behind in such care (Poeze \& Mazzucato, 2013).

The characteristics of the caregiver are also important. Usually, women are caregivers even when the father is in the country and the mother has migrated (Åkesson et al., 2012; Banfi \& Boccagni, 2011; Parreñas, 2005). When fathers migrate, the child's biological mother is usually the caregiver. When a mother migrates, the caregiving responsibility is transferred to grandmothers, aunts, older sisters, or other female kin. A study by Nobles (2011) indicates that if the mother is the caregiver and is married to the migrant parent, she is more likely to facilitate the relationship between the migrant father and his children than when this is not the case. Migrant fathers who are divorced or separated are less involved with their children back home than fathers who are in a relationship or married to the biological mother. Dreby (2006) found similar results: Mexican migrant fathers and mothers in the US who were divorced had less and more problematic contact with their children in Mexico. 


\subsubsection{Length of separation}

Decisions to migrate are often based on achieving a particular aim (Bryceson \& Vuorela, 2002), such as earning enough money to enable one's children to attend good schools or to be able to live comfortably in the country of origin. Once these goals have been accomplished, migrants often intend to return home. However, these goals, which are established beforehand, are often not met in the intended time period, if at all, or new goals are set. Furthermore, some parents intend to bring their families once they are settled in the host county, but strict migration policies prohibit this reunification. Therefore, although parents often migrate intending the separation with their children to last only a short time, they typically are separated for longer than anticipated (Dreby, 2006).

Some authors have stated that the longer parents are separated from their children, the more likely it is that they will grow apart (Carling et al., 2012), although this issue has not been researched directly. In particular, indefinite and uncertain separations can cause stress and frustration amongst children in the home country. As a result, long periods of separation can have a negative influence on the relationship between a parent and his/her children (Fresnoza-Flot, 2009). Waters (2011) also argued that lengthy separations can deteriorate the bond between parents and children, although this was not the specific focus of her study and she reports only on one such case. Yet others have argued that time can make separation easier to deal with. A study by Schmalzbauer (2008) showed that children find ways to cope with the separation and adapt to relationships with their parents that take place and are maintained over the phone instead of through physical contact. Some youth interviewed by Schmalzbauer stated that they had better relationships with their parents because of their appreciation for what their parents did for them. However, the interviewed youth all stressed that the separation was supposed to be temporary, and knowing that their parents would return eventually made the separation easier to deal with. Thus, prolonged separation can either intensify or negatively influence the relationship between migrant parents and their children back home.

\subsubsection{Age of child and age at separation}

The age of the child and the age at separation are likely to affect the relationship children maintain with their parents and caregivers. A person's emotional and material needs are strongly linked to the stages of the individual life cycle (Bryceson \& Vuorela, 2002). A younger child needs to be nurtured, whereas an older child may also seek parental guidance and advice. If a child is left in the care of someone else for extended periods of time at a young age, the child may not have a vivid memory of the parent (Schmalzbauer, 2004) and may derive emotional and material care from a caregiver. At the same time, as observed among children in divorced families (Zill, Morrison, \& Coiro, 
1993), young children may be more vulnerable to family disruption because, unlike older children, they are less able to understand the situation (Schmalzbauer, 2004). Young children are more dependent on their parents and therefore less able to escape the effects from family disruption through school and other activities or through interaction with peers (Zill et al., 1993). A study of children in China who had at least one parent who migrated found that children who were separated at age three experienced more emotional distress than children who were separated at an older age (Fan, Su, Gill, \& Birmaher, 2012). Furthermore, non-physical communication with young children is difficult, which may affect the parent-child relationship.

In contrast, children who have separated at an older age have vivid memories of their parents and of the time they lived together (Schmalzbauer, 2004). As a result, separation may be traumatic because they long to live together with their parents. However, they are old enough to better understand the separation. Additionally, communication with older children is very different from communication with young children. Unlike younger children, older children can directly communicate with their parents and express how they feel about the separation and their wants and needs. Finally, migrant parents may have difficulties with children growing older without them present; they retain an outdated image of their child in the home country, imagining them to be younger and more dependent than they really are. This situation may lead to frustrations on both sides (Dreby, 2006).

In sum, we can hypothesise that differences exist between the relationships fathers and mothers have with their children. Parents who have more contact with their children and send remittances have better relationships with their children. If the parent perceives that the care provided to the child is good, the parent-child relationship will also be evaluated as good; if the caregiver and migrant parent are divorced/separated, the parent-child relationship will be poorer. The length of separation also affects the parent-child relationship, although the direction of this relation is unclear. Finally, the age of the child and the age at separation affect the parent-child relationship; again, however, the direction of this relation is unclear. These factors have not been researched using survey data, nor have they been analysed concomitantly by controlling for demographic, migration, and socio-economic factors. Furthermore, in comparing two migratory flows that are characterised by different sending conditions and at the same time face very different migration regimes in The Netherlands, we hypothesize that differences between migrant groups in their home and host country conditions shape the relationship between the above factors and the parent-child relationship. This issue has not been previously researched therefore we cannot derive concrete hypotheses from the literature. Below, we describe the two migration flows to better interpret our findings of the similarities and differences between the two flows. 


\subsection{Angolan and Nigerian migrants in The Netherlands}

Recent Angolan emigration is mainly the result of the war that raged in Angola from its independence from Portugal in 1975 until 2002. Especially from 1998 onwards, extreme fighting resulted in many Angolans fleeing to neighbouring countries as well as to Europe. The Netherlands became a major destination for Angolan asylum seekers due to the favourable laws at the time, resulting in a quadrupling population between 1998 and 2004 from 3,352 to 12,281 (Central Bureau for Statistics, 2013). The Angolan migrants who came in that period were of middle-class backgrounds. Approximately half came as unaccompanied asylum-seeking minors (UAM) (Wijk van, 2007), who were under the age of 18 and migrated without other family members. After the war ended in 2002, it became difficult to migrate to The Netherlands as an asylum seeker because Angola was classified as a safe country by the Dutch government. Many Angolans returned home, either involuntarily or voluntarily. This situation led to a sharp decrease of Angolan residents in The Netherlands, reaching 8,500 by 2013 (Central Bureau for Statistics, 2013).

In contrast, Nigerians in The Netherlands have steadily increasing in numbers, from 3,136 in 1996 to 11,466 in 2013. In addition, a significant number of undocumented Nigerians reside in The Netherlands, although their numbers are unknown (Haas de, 2006). In contrast to Angolans, Nigerians mainly entered The Netherlands through family reunification (including a significant proportion of family formation), followed by labour migration. In addition, a large group of Nigerians entered The Netherlands on a tourist visa and then stayed in the country once their visa expired. Compared to other sub-Saharan African migrants, few Nigerians came to The Netherlands as asylum seekers (Central Bureau for Statistics, 2013).

Both migration streams are quite recent and, consequently, are characterised by young populations. The main differences in individual characteristics between the two groups relate to marital and socio-economic status and household structure. Ten percent of Angolan households are headed by single parents, whereas 5 percent of the Nigerian and 2.5 percent of the native Dutch population are headed by single parents (Central Bureau for Statistics, 2013). Additionally, although 17 percent of the Nigerian population in The Netherlands is married, only 10 percent of the Angolan population is married (Central Bureau for Statistics, 2013). Furthermore, in contrast to Nigerians, most Angolans speak Dutch fluently because UAMs were placed in foster care and received Dutch education. A quarter of the Nigerians in The Netherlands have completed tertiary education (Heelsum, 2005), whereas Angolans have primarily completed vocational training. Yet, although Nigerians have higher education degrees they are often not recognized while this is not an issue for the Angolan UAMs who have obtained their degrees in The Netherlands. Consequently, there is a larger share of Nigerians who are in unskilled labour as well as unemployed. 
The different migration regimes that these two groups faced upon entry has resulted in a large share of undocumented Nigerians and of low socio-economic status as opposed to a large share of Angolans who have obtained Dutch citizenship or permanent residency. Consequently, Nigerians are in a more precarious position in Dutch society. These differences in socio-economic and legal standing have implications for parents wanting to reunite with their children in The Netherlands. According to Dutch family reunification law it is only possible to reunite with children if a parent has a certain level of stable income, which for many Nigerians is difficult to realise. For refugees this procedure is different as there is no income requirement for reunification within the first three months of arrival. After that similar conditions apply as for labour migrants (Defence for children \& Vluchtelingenwerk Nederland, 2012), however Angolans' better economic standing and Dutch citizenship status makes it easier for them to qualify.

Based on these differences in the migration characteristics of the two populations, we can expect some differences in transnational parent-child relationships. First, leaving one's child behind in a war or post-war country with hazardous circumstances can be extremely stressful. Parents and children who were separated during the war or shortly thereafter are likely to have experienced greater trauma. This trauma may increase the effect of the parent-child separation on the well-being of parents and children and on the relationship they maintain (Suarez-Orozco et al., 2002). In addition, being an asylum seeker without the right to work and the lack of good infrastructure in Angola may restrict migrant parents' ability to contact their children in the home country and to send remittances in the first period of their arrival to The Netherlands. In later stages of the parent-child separation, when Angolan parents have gotten their refugee status and/or citizenship, children may feel abandoned if the separation continues, leading to strained relationships. These situations lead us to hypothesise that Angolan parents are more likely to evaluate their relationships with their children back home negatively. However, other tendencies may indicate the opposite. Many Angolans obtained Dutch citizenship after receiving their refugee status, enabling them to work and freely travel to and from Angola. This situation can facilitate regular physical contact and regular remittance sending, which, in turn, can facilitate good relationships. At the same time, for many undocumented Nigerians, it is difficult to maintain regular contact through home visits and to send remittances regularly. This situation leads us to hypothesise that Nigerians are more likely to negatively evaluate their relationships with their children in the home country. 


\subsection{Data and methods}

\subsubsection{Data}

This study draws on data collected amongst Angolan and Nigerian parents living in The Netherlands as part of the TCRAf-Eu project. The survey was conducted between November 2010 and October 2011 with the help of 20 interviewers in the cities of Amsterdam, The Hague, and Rotterdam for the Nigerian sample and in Amsterdam, Utrecht, Rotterdam, and a few other areas of The Netherlands for the Angolan sample because Angolans are spread out as a result of their placement in asylum-seeker centres. Three hundred migrant parents were targeted per flow. Purposive sampling was used to allow for a sample composed of half migrant parents living with all their children in The Netherlands and half migrant parents with at least one child in the country of origin. The latter group was used for the analyses in this paper. Migrant parents with children under the age of 21 were included in the sample. This age limit is three years beyond the official age at which children can be reunified with their parents according to Dutch law. However, we used the upper bound of the age limit when parents are likely to be involved in parenting based on previous interviews with parents. Other criteria for inclusion were that the respondents should have migrated to The Netherlands at age 18 or older in the Nigerian case and age 16 and older in the Angolan case ${ }^{11}$. Furthermore, the parents had to have spent at least one consecutive year in The Netherlands. We intended to include an equal proportion of men and women across different age groups. One migrant parent per household was interviewed.

Different interviewers were recruited to allow for a diverse sample (young and older, male and female, students and workers, and of Angolan, Nigerian, Ghanaian, and European backgrounds) because they were able to access different types of respondents. Furthermore, different gateways were used: personal contacts, churches, hometown organisations, cultural projects, city and government departments, and snowball sampling. The sampling procedure resulted in 296 Nigerian and 306 Angolan migrant parents with children in The Netherlands and/or the country of origin. In this paper, we were interested in the parent-child relation with children living in the country of origin; thus, we used the sub-sample of respondents who had at least one child under the age of 21 living in the country of origin, resulting in 131 Nigerian and 134 Angolan migrant parents.

\footnotetext{
${ }^{11}$ We decided to lower the age by two years for Angolan migrants because most Angolans came to The Netherlands as unaccompanied minors; consequently, the research population is relatively young.
} 


\subsubsection{Measures}

The dependent variable in this study, the parent-child relationship, is measured based on the question, 'How would you describe your relationship with [child's name]?' Response options included 'always open/warm', 'often open/warm', usually 'open/warm', 'sometimes open/warm', 'hardly ever open/warm', and 'never open/warm'. To account for skewness in this variable, we created a binary variable by recoding the last four responses into one category, coded 1, which we refer to as poor relationship and recoding the first two responses in another category, coded 0 , indicating a good relationship. Because a migrant parent may have multiple children for whom he or she answered this question, a score of 1 was assigned when a respondent reported having a poor relationship with at least one of the children living in the country of origin. Based on the transnational family literature, we included the following as independent variables: gender, whether remittances were sent monthly, whether the caregiver was the biological parent of the child, whether the biological parents were in a relationship or married, whether the respondent was dissatisfied with the care the child received, length of separation in years, the average age of the respondents' children at separation, whether the respondent had children under the age of 8 , and whether the respondent had children over the age of 14 . Furthermore, the amount of contact with the child was included as a continuous measure, coded 1) Not at all; 2) Once or twice a month; 3) Once a week; 4) A few times a week; and 5) 'Everyday'. Finally, we controlled for migrant group, age, marital status, legal status, and, as a measure of socio-economic status, housing.

\subsubsection{Descriptive statistics}

Table 4.1 displays the descriptive statistics of the variables according to the migrant group. Most respondents were married, male, had regular contact with their children, and were mostly satisfied with the care provided to the child. The caregiver was most often the other biological parent and was not in a relationship or married to the migrant. More Angolan parents reported having a poor relationship with their children (40 percent) than did Nigerian parents (19 percent), and this difference was statistically significant. Furthermore, in the Nigerian sample, the parents were older, were more likely to be married, were less likely to live in a house/apartment, had more contact with their children, sent fewer monthly remittances, were more often satisfied with care, migrated when their children were older, and had fewer children under the age of 8 than Angolans. Moreover, although approximately 28 percent of the Nigerians in our sample were undocumented, only two Angolan respondents in our analytical sample were undocumented. 
Table 4.1. Descriptive statistics $(\mathrm{N}=256)$

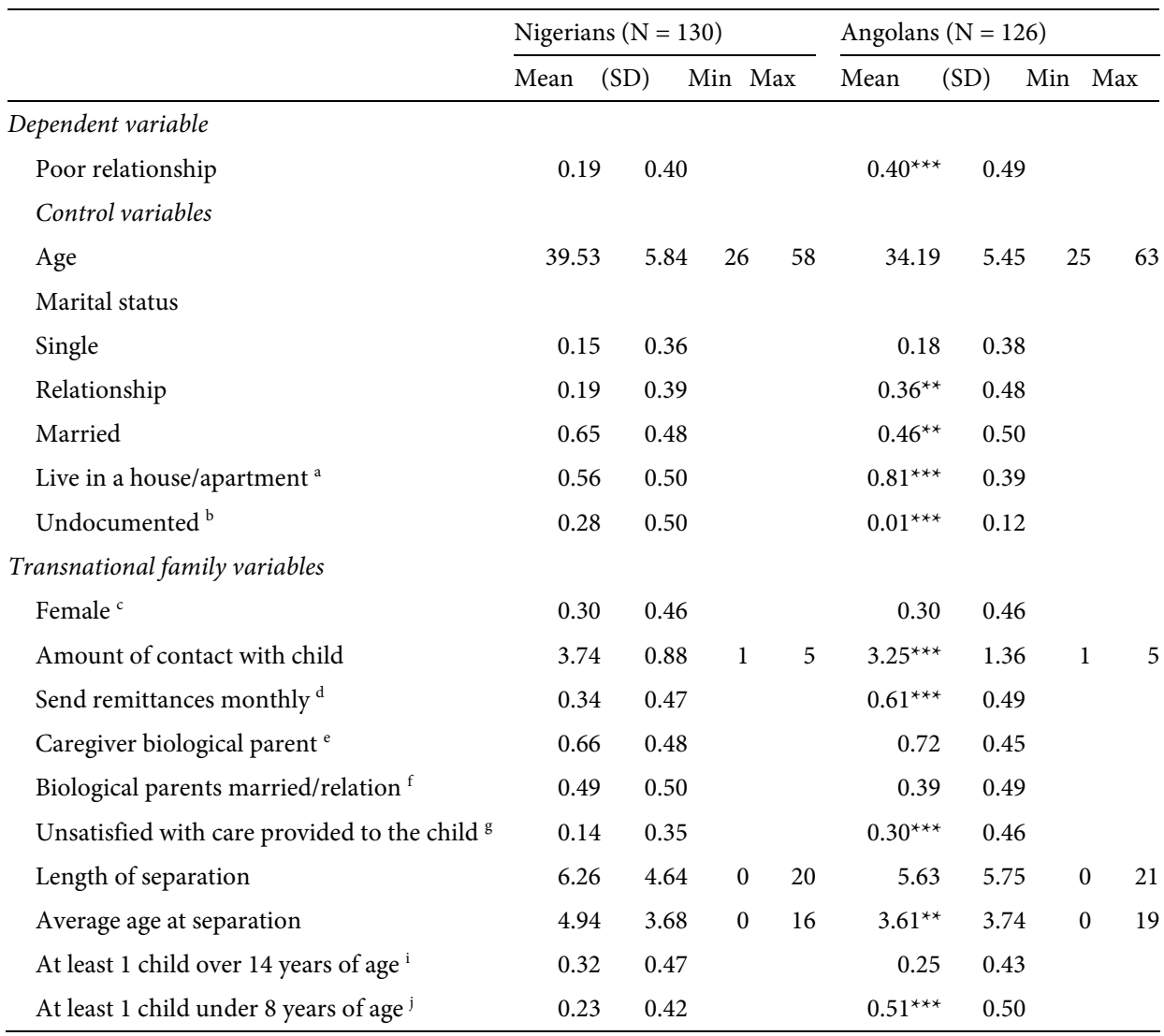

Source: TCRAf-Eu parent survey Netherlands, 2010-2011.

Notes: Distribution and Pearson's chi-square tests, indicating differences between the Angolan and Nigerian sample, presented for categorical variables and means, standard deviations and t-tests presented for continuous variables. Significance level: ${ }^{\star} \mathrm{p}<0.05 ;{ }^{* *} \mathrm{p}<0.01 ;{ }^{\star * *} \mathrm{p}<0.001$.

The reference category for the respective variables are: a) room, student housing, institution, other; b) documented status; c) male; d) sends remittances once a month or no remittances at all; e) current caregiver is not the biological parent child; f) respondent and the other biological parent of the child are separated; g) parent is satisfied with the care provided; i) the respondent does not have children over 14 years of age; $j$ ) the respondent does not have children under 8 years of age.

\subsubsection{Statistical analyses}

Binary logistic regression was employed to examine the association between the variables of interest and the parent-child relationship. Due to the small sample size, we estimated a single model for both the Nigerian and Angolan groups. Model 1 includes the basic socio-economic control variables. Model 2 additionally includes the transnational family variables as identified from the transnational family literature reported in section 1 . Each variable was added in a step-wise fashion to discern the influence of each 
variable separately on the parent-child relationship. Due to space limitations, we report the full model in model 2 rather than showing each step-wise addition. Due to multicollinearity between the length of separation and the other age of child variables, we ran two models by including only the length of separation (model 2) and by including the other age variables (model 3) separately. To account for differences between the two migrant groups, we included interaction effects. Only significant interaction effects are reported. Model 4 adds the interaction effects to model 2, and model 5 adds the interaction effects to model 3.

\section{$4.5 \quad$ Results}

The results of the binary logistic regression are displayed with odds ratios in Table 4.2. We find some evidence for the importance of the hypothesised factors in association with the parent-child relationship. We will discuss each factor separately.

\subsubsection{Gender}

There are no differences in how migrant fathers and mothers assess their parent-child relationship. Our hypothesis, based on transnational family literature, that gender would affect parents' assessments of their relationships with their children back home is not supported.

\subsubsection{Contact and remittances}

The amount of contact with the child is significantly related to parents' relationship with their children. A one-unit increase in contact leads to a 52.6 percent decrease in the odds of having a poor parent-child relationship in model 3. Hence, increased odds of having a poor relationship are associated with limited amounts of contact with the child. Whether remittances are sent monthly is not significant, nor is the interaction between the migrant group and this variable (not shown).

\subsubsection{Caregiver}

We hypothesised that if the caregiver was the other biological parent and if both biological parents were still together in a relationship or married, this situation would facilitate a good relationship between migrant parents and children. The analysis confirms this hypothesis. Being married to or in a relationship with the biological parent of the child decreases the odds of having a poor parent-child relationship by 66.6 percent in model 2 . However, this association ceases to be significant when age-related variables are added to the model. Finally, we hypothesised that dissatisfaction with the care provided to the 


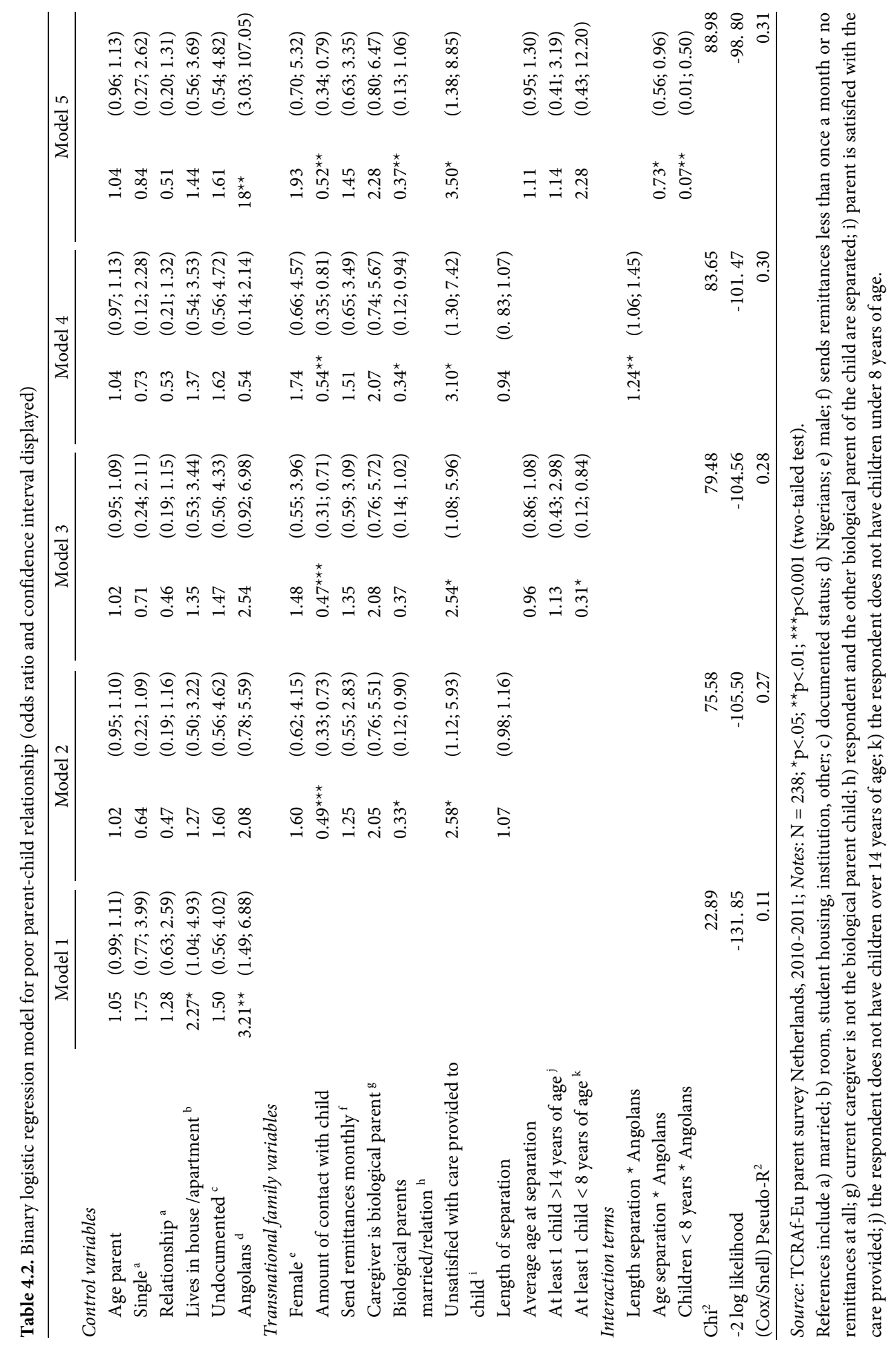


child would inhibit a good relationship with the child. We find strong support for this hypothesis. Dissatisfaction with care increases the odds of a poor parent-child relationship by 157.9 percent in model 2 . The interaction effects between these variables and the migrant group are insignificant, indicating that the effects found are similar for both groups.

\subsubsection{Length of separation.}

In model 2, we include the length of separation and find that it is not significant. However, the interaction term between migrant group and length of separation in model 4 is significant. This finding indicates that there are significant differences between the migrant groups regarding the effect of length of separation. When we run separate analyses for the two migrant groups (results not displayed), we find that length of separation is only an important and significant predictor in the Angolan model. The longer Angolan parents and children are separated, the more often a poor relationship is reported. Thus, the hypothesis is confirmed, but only for Angolan migrants.

\subsubsection{Age at separation and age of child.}

We hypothesised that the age of the children and age at separation would affect the parent-child relationship, but we did not hypothesise a specific direction. When these variables are added in model 3 , we find that having children under the age of 8 decreases a parent's odds of having a poor relationship with the child by 68.8 percent. The presence of children older than 14 and the age at separation are not found to be significant. The interaction terms in model 5 are, however, significant for migrant group and age at separation, and migrant group and children under 8 . This finding indicates that the associations work differently for the two migrant groups. For Angolans only, we find that the average age at separation is significantly related to the parent-child relationship: the younger the children are when separated, the more often a poor relationship is reported. Furthermore, the effect of having children under the age of 8 is only significant for Angolans, and the association between the child's age and the parent-child relationship is more pronounced for this group.

\subsubsection{Control variables}

Interestingly, for the control variables, we find in the first model that living in a house/apartment (and, hence, having higher socio-economic status) and being Angolan increase parents' odds of having a poor relationship with their children back home. However, when the transnational family variables are added, these variables cease to be significant, suggesting that their impact is likely confounded or mediated by the trans-

national family variables included in models 2 and 3. 
In sum, we find that whether the parent maintains regular contact with the child, is in a relationship with or married to the other biological parent, is satisfied with the care provided to the child, and has young children are related to how parents evaluate their relationship with their children at home. Furthermore, we find that for Angolans, age of child, age at separation and length of separation are also important indicators of a poor parent-child relationship.

\subsection{Discussion and conclusion}

The transnational family literature indicates that transnational child-raising arrangements can challenge relationships between migrant parents and their children who remain in the home country (Hondagneu-Sotelo \& Avila 1997; Horton 2009; Parreñas 2005). Factors that are identified as having important effects on this relationship are gender, contact and remittances, characteristics of the caregiver, length of separation, and the age of the child and age at separation. However, few studies have investigated how these factors are associated with the parent-child relationship. More importantly, to our knowledge, no study has investigated these factors simultaneously. Using a dataset collected expressly for this purpose, we explore the associations between multiple factors and the parent-child relationship, and we distinguish the relative importance of these factors.

Despite the negative emotional consequences of parent-child separation reported in the above literature, we find that most migrant parents report having good relationships with their children, although Angolans more often report poor relationships than Nigerians do. In line with the literature, we find that contact between the migrant parent and child is strongly associated with a good relationship (Carling et al. 2012; Parreñas 2005; Zentgraf \& Chinchilla 2012). The analysis of two different migrant groups helps to investigate important factors associated with parent-child contact further. In addition to reporting good parent-child relations more often, Nigerians report significantly more contact with their children than Angolans do. When we add only the amount of contact to the logistic regression and include control variables, we find that the migrant group is no longer significantly associated with the parent-child relationship. Hence, the amount of contact is important in explaining why we find differences between the quality of Angolan and Nigerian parent-child relations.

The caregiver is also an important element in how a parent assesses his or her relationship with the child. We find that the identity of the caregiver and whether the other biological parent, who is usually the current caregiver, is married or in a relationship with the migrant parent are of crucial importance in facilitating transnational parent-child relationships. This finding corroborates some of the findings in the transnational family literature (Dreby, 2006; Nobles, 2011; Schmalzbauer, 2008), which argues that divorce negatively affects transnational parent-child relationships. Additionally, we find that satisfaction with care is associated with a good parent-child relation- 
ship. This finding suggests that when a child does not receive good care, separation may be more traumatic, and children may reproach their parents more often for leaving them behind, resulting in a poor relationship between the parent and child (Tizard, 1991). Likewise, dissatisfaction with care may lead to tensions between migrant parents and caregivers back home. Children may react to these tensions by distancing themselves from their migrant parent (Dreby, 2006).

Surprisingly there is a lack of significance between the relationships reported by migrant fathers and mothers. The majority of transnational family studies report that the relationship between migrant mothers and their children is different from that of migrant fathers. Parreñas (2008), for example, states that migrant fathers are less present in the lives of their children than migrant mothers are and concludes that fathers and children more often lack intimacy across borders. Likewise, Dreby (2006) reports that children seem to suffer more when their mothers migrate than when fathers do. This can potentially affect the parent-child relationship. However, most transnational family studies research focuses on migrant mothers (Mazzucato \& Schans, 2011). One reason that we find no gender differences may be the fact that men's perceptions have rarely been studied; hence, we know little about how they perceive the parent-child relationship (Poeze \& Mazzucato, 2012; Pribilsky, 2004).

Our other results are mixed and only partly confirm the hypotheses because they apply only to the Angolan sub-sample. These findings concern age at separation, having children younger than 8 years of age, and length of separation. The different conditions at origin and of reception in The Netherlands for the Angolan migrant group can help to explain these findings. The war in Angola, which lasted until 2002, created a situation in which migrant parents who migrated more than 8 years prior to the survey, left children in a country at war. As Suarez-Orozco and co-authors (2002) state, coming to terms with family separation is more disruptive and harder to cope with when a child also faces other dramatic changes in his or her life, such as war. During war, contact with children is easily lost, and children may reproach their parents for having left them behind in such circumstances, thereby negatively affecting the parent-child relationship. Corroborating this hypothesis, some Angolans in our sample did not know the whereabouts of their children or if they were alive after the war.

A second possible explanation for differences between Angolan and Nigerian parent-child relationships is if there were different family norms pertaining to child raising in the two countries where in one country parent - child separations would be more normalised. Yet in both Nigeria and Angola, as in other parts of sub-Saharan Africa, child fosterage, where children are 'given' to an extended family member to raise, is commonplace as is the practice of social parenthood, where people other than the biological parents play important roles for the upbringing of a child (Isiugo-Abanihe, 1985; McDaniel \& Zulu, 1996; Øien, 2006). As such, there is no indication that norms around child upbringing and parenting differ substantially between the two countries 
that would lead to differences in the assessed quality of parent - child relationships. We therefore exclude this as a likely explanation.

A third explanation for the differences found between the groups relates to the migration regimes Angolans and Nigerians faced when coming to The Netherlands. Angolans have predominantly entered The Netherlands as asylum seekers, have obtained residence permits or Dutch citizenship and have earned educational degrees in The Netherlands allowing them to relatively easily enter the work force. Nigerians have come to The Netherlands as economic migrants. Stringent entry requirements for labour migrants has led Nigerians to use multiple other ways to enter The Netherlands, e.g. through family reunification or overstaying tourist visas, the latter leading to a precarious position in Dutch society. Furthermore they experience difficulties in having their credentials recognized, often leading to low-level jobs. As such, Angolans may be more oriented towards their lives in The Netherlands and less focused on maintaining a relationship with family members back home. In fact, in our sample, most Angolan parents, in contrast to Nigerians, have no intention of returning to Angola. Schmalzbauer (2008) has argued that for children, knowing that their parent will return makes separation easier to address. Furthermore, for Angolan children, knowing that their parent could apply for reunification in The Netherlands but does not, may lead them to feel abandoned, thus straining the relationship with their migrant parent. On the other hand, as Angolans face more favourable conditions to be able to meet the income and legal residency requirements of Dutch reunification law, it may be that parents with a good relationship with their children have reunited with them and what we are observing are those parents who, because of their poor relationship with their children, did not reunite, i.e. a reverse causality. Because our data is cross-sectional we cannot assess the direction of causality. Unpacking exactly how home and host country contexts influence parent - child transnational relationships is a valuable direction for future research. Future research should also address children's perceptions of the parent-child relationship, as separation is experienced differently by various members of the family (Bryceson \& Vuorela, 2002; Fresnoza-Flot, 2009; Parreñas, 2005).

In sum, our analysis of parent-child relationships in transnational families amongst two groups of migrant parents highlights two important additions to transnational family studies, which are usually conducted on one migrant group. First, particular characteristics seem to be generally associated with better parent-child relationships irrespective of the origin group characteristics. Frequent contact, satisfaction with the care being provided by the caregiver, and being in a relationship or married to the caregiver back home are generally associated with a positive parent-child transnational relationship. Second, some aspects of transnational parent-child relationships are particular to the migrant origin group, such as the length of separation, age of the child at separation, and having young children. This finding suggests that the context in which migration occurs is relevant. Both conditions in the home country as well as 
conditions that parents face in the host countries influence the way transnational relationships are experienced by parents. It is important to consider these in debates, policy and law making concerning migrant families. 


\section{CHAPTER 5.}

\section{Subjective well-being of transnational parents}

This chapter will be published as Haagsman, K., Mazzucato, V. \& Dito, B. (in press). Transnational parents and the subjective well-being of migrant parents: Angolan and Nigerian parents in The Netherlands. Ethnic and Racial Studies. 



\subsection{Introduction}

Transnational families in which one or more nuclear family members are located in different countries are a common phenomenon in contemporary migration trends. One form of transnational families is when parents migrate while leaving their children behind in the care of relatives or other caregivers while they search for better employment opportunities abroad to provide for their children. Economic studies have pointed to the benefits that arise from this type of migration, such as helping families out of poverty and enabling family members to access education and health services. However, transnational family studies have emphasised that such benefits come with an emotional cost.

An increasing body of research has studied the effects of transnational family life and shows that parent-child separation can have negative consequences for the wellbeing of migrant parents. Migrant parents, especially migrant mothers, state they feel guilty, lonely and depressed and long to be with their children (Hondagneu-Sotelo and Avila 1997; Parreñas 2001; Aranda 2003; Schmalzbauer 2004; Horton 2009). Such studies have been valuable in drawing attention to the phenomenon of transnational families, in investigating how migrant parents organise care of their children and how their transnational lives affect the relationships of the people involved. This study contributes to this mainly ethnographic body of literature by taking a quantitative approach, allowing the study of psychological and physical impact of family separation on migrant parents while controlling for other characteristics that may be affecting parental well-being. Additionally, this study adds to previous studies on transnational families by comparing transnational with non-transnational families, enabling the investigation of whether poor well-being ascribed to separation is indeed related to transnational family life and not to other factors (Mazzucato and Schans 2011). In this study, data collected amongst Angolan and Nigerian migrant parents in The Netherlands, make it possible to compare the subjective well-being of migrant parents whose children live in the country of origin to migrant parents living with their children in The Netherlands, while controlling for individual attributes such as socio-economic, legal and marital status, which could be related to differences in well-being.

In addition to individual level characteristics, this study explores contextual level factors. The conditions in which parents leave their children in the country of origin as well as the different contexts in which parents find themselves in the receiving country may have an impact on how parents organise and experience transnational family life. To investigate this, it is necessary to compare effects across different contexts; however, to date, transnational family studies have predominantly focused on case studies of a single country of origin and use different methodologies across cases, making it difficult if not impossible to draw comparisons. This paper compares Angolans and Nigerians who live in the same country, The Netherlands, under very different conditions. It uses 
the same methodological tools in both cases enabling a comparison of effects. As such, the paper investigates whether the relationship between parental well-being and parentchild separation is similar across cases or if sending and receiving country contexts impact this relationship.

The focus of the paper on cases of African parental migration to Europe is of interest since most transnational family studies have focused on migration from Latin America and Asia, largely ignoring African migrants who are an important part of Europe's 'new' migrant populations (Koser 2003).

\subsection{Theoretical background}

This paper brings together two literatures that have, to date, remained largely independent of each other: transnational family studies and migrant well-being literature. The former consists of qualitative anthropological and sociological studies and focuses on the emotions of parents and children in transnational families, whereas the latter, drawing from quantitative clinical psychology, social psychology and sociology, has investigated individual and contextual factors affecting migrant well-being without a specific focus on transnational family forms.

\subsubsection{Transnational families}

Transnational family studies have highlighted that parent-child separation leads to low emotional well-being of parents. Limited physical interaction makes engaging in intimate relations with children in the country of origin challenging and, consequently, the parent-child bond suffers (Parreñas 2005; Horton 2009). This loss of intimacy and frustrated efforts to maintain close bonds with children can cause severe emotional distress for both parents and children who feel that the bond is deteriorating (Bernhard, Landolt, and Goldring 2009). Parents also feel guilty as children reproach their parents for leaving them behind (Bernhard, Landolt, and Goldring 2009; Fresnoza-Flot 2009). A recent study shows the majority of Angolan and Nigerian transnational parents in the Netherlands report having a good parent-child relationship but that transnational family life can, under certain circumstances, affect the parent-child relationship negatively (Haagsman and Mazzucato 2014).

In addition to the quality of the parent-child relationship, the age of the child can impact on the well-being of migrant parents. Young children are more dependent on their parents and are less able to understand the separation; therefore, family disruption is especially challenging for them (Schmalzbauer 2004). At the same time non-physical communication with young children is difficult, making separation especially challenging for migrants with young children. 
Long and often unplanned separations contribute to migrant parents' feelings of losing their role as the main caregiver or primary decision maker in the upbringing of their children. This is especially true when parents feel unable to intervene in child-related crises, such as illness (Aranda 2003; Mazzucato and Schans 2011), or to participate in milestone events such as birthdays or graduations. Some literature suggests that time makes separation easier to cope with as parents learn how to cope with the physical separation and children adjust to their new caregivers (Schmalzbauer 2008). Although no research explicitly compares parents of different economic levels and documented status, studies mention that low-income and undocumented status impede parents from fulfilling their parenting roles (Dreby 2010; Fresnoza-Flot, 2009).

Transnational family literature suggests that women are more emotionally affected by the separation than men because norms of 'good mothering' held by migrant women and society at large in their origin countries see women as the primary caregivers and responsible for reproductive care work (Hondagneu-Sotelo and Avila 1997; Parreñas 2005). Geographic distance impedes mothers from fulfilling these roles and as a result, women feel guilty, ashamed and stigmatised (Parreñas 2001; Aranda 2003; Bernhard, Landolt, and Goldring 2009). Conversely, fathers are expected to play the role of financial providers for the family, a role that can be enhanced by migration.

\subsubsection{Migrant well-being}

Migrant well-being is studied predominantly in clinical and social psychology literature that focuses on migrants' acculturative stress and ill mental health when coming into contact with and adapting to a distinct majority culture as well as in sociology of migration literature that studies the relationship between migrants' poor integration in a host society and low subjective well-being.

Sociological research on migrant well-being links low socio-economic status (unemployment, low income and low education), marital disruption, low social support or a small social network and being a woman to increased health problems. Negative life events and chronic strain are also associated with health problems (Vega and Rumbaut 1991; Sudano and Baker 2006; Kennedy and McDonald 2006). Social psychological stress theory is used to explain these associations. The theory posits that certain groups experience a greater degree of particular stressors because they face many life changes and cannot cope with them due to a lack of resources (Pearlin et al. 1981). Migrants have a higher chance of experiencing health and psychological problems due to their experiences with high unemployment, disrupted marital relationships, fragmented social networks and the physical hardships they often face, especially when undocumented (Jolivet et al. 2012). Furthermore, their experiences of unfair treatment and discrimination, language inadequacy and living in unfamiliar environments can lead to a sense of disorientation and an increase in their vulnerability (Kessler 1979; Vega and 
Rumbaut 1991; Safi 2010; Fassaert et al. 2011), which a longer stay in the host country helps to ameliorate (Hovey 2000; Kennedy and McDonald 2006).

Particular stress can be experienced by working parents who must arrange care for their children (McLanahan and Adams 1987; Umberson 1989). An important coping mechanism to address this stress, according to migrant well-being research, is the support of family members in the host country (Prilleltensky 2008; Hovey 2000). Family support is helpful for providing childcare, especially for migrants who may have difficulty in accessing formal child care institutions and have to work long hours. This is especially pertinent for women and single parents with pre-school children (Spitzer et al. 2003).

However, the majority of clinical psychology literature is based on clinical data on migrants with mental disorders who are in need of treatment, and therefore, extreme cases, and hence are likely to overestimate migration effects (Vega and Rumbaut 1991; Suarez-Orozco, Todorova, and Louie 2002). In non-clinical and sociological studies, migrant groups are generally compared to the native population to assess their wellbeing (Rechel et al. 2013). This approach does not allow us to understand the heterogeneity within migrant groups due to, for example, length of stay, connections to their home countries or different family formations, all factors that are emphasised in transnational family studies. Such factors affect the way migrants live and perceive their lives in the host country and are, therefore, important to take into account in well-being research.

A commonality of migrant well-being studies is their focus on migrants' lives and characteristics pertaining to the hosting societies, reflecting a general bias in social psychology and sociology studies to focus on nuclear, co-resident families or separated families due to divorce or crisis events (Mazzucato 2013). Separation due to migration resulting in transnational families has generally been ignored in migrant well-being research (Suarez-Orozco, Todorova, and Louie 2002; Horton 2009; Reynolds and Zontini 2006; Evergeti and Zontini 2006; Mazzucato and Schans 2011). An exception is a study by Hovey (2000) that took family ties in the country of origin into account. He found that migrants with most family members living in the country of origin experienced more acculturative stress than migrants who had most family members living in the host country.

\subsection{Angolans and Nigerians in The Netherlands}

This paper compares two migrant groups that have similar family and child raising norms, but have different migration trajectories to The Netherlands allowing us to explore in what way the context of migration plays a role in the effect transnational family separation has on subjective well-being. As in other parts of sub-Saharan Africa, in both countries child fosterage and social parenting are practiced, in which care for a 
child is shared by the extended family and people other than the biological parents can be the primary caretakers for some time (Isiugo-Abanihe 1985; McDaniel and Zulu 1996; Øien 2006). Social acceptance of parent-child separation in Angola also ensued after a long period of civil unrest resulting in many disrupted families (Nzatuzola 2006). It has been estimated that in 2010, 33 per cent of the children in urban Angola did not live with both parents, excluding orphans (INE 2010). In addition, Nigerian transnational family life is not a new phenomenon and has already been observed in the 1980s (Eades 1980). In 2008 it was estimated that approximately 30 per cent of Nigerian children, excluding orphans, did not live with both parents (NDHS 2008). Therefore, Angolan and Nigerian parents might not experience the same emotional distress that is described for transnational families from regions where family norms are different (Mazzucato \& Schans, 2011). By selecting countries with similar family and child raising norms such as Angola and Nigeria, we exclude differences in cultural practices around families at origin as a likely explanation for any differences we may find between the two groups. This is necessary as we are particularly interested in understanding how differences in the conditions in the receiving country could affect the impact transnational parent-child separation has on the parents' subjective well-being.

Important differences between the two groups lie in their migration histories, and thus the conditions they face in The Netherlands. There are 8,575 and 11,466 first- and second-generation Angolans and Nigerians, respectively, in The Netherlands (Central Bureau for Statistics 2013). Nigerians arrived for a variety of reasons encompassing education, employment and family formation and reunification, while Angolans came to The Netherlands primarily to seek asylum as a result of the war in Angola between 1975 and 2002. Many came when they were younger than 18 years of age and were therefore categorised as Unaccompanied Asylum seeking Minors (UAM) (Wijk van 2007).

These differences in migration history have important consequences for how migrants feel as well as for the rights they have in The Netherlands. Refugees and asylum seekers generally experience high levels of psychological distress because they have had less control over their migration and did not desire this change (Vega and Rumbaut 1991). Leaving family and friends behind in a post-conflict society and trauma from family tragedy, political and/or ethnic persecution or war can compound the effect that separation has on the well-being of the migrant (Suarez-Orozco, Todorova, and Louie 2002).

On the other hand, an inhospitable context of reception can also lead to low subjective well-being (Vega and Rumbaut 1991). Nigerians are proportionately more likely to be undocumented in The Netherlands, making it difficult for them to access basic services such as health and education and to be protected under Dutch labour laws. Furthermore, although a large group of Nigerians in The Netherlands has obtained tertiary education, qualifications are often not recognised (Heelsum and Thomas 2006), 
resulting in a larger share of Nigerians who are in unskilled labour or unemployed. A compounding factor is their low Dutch language proficiency. These factors make this group particularly vulnerable and hence could result in low levels of subjective wellbeing. Hence, for both groups the migration trajectory can lead to high levels of stress and low well-being, albeit in different ways.

\subsection{Data and Methods}

\subsubsection{Data}

A survey was conducted between November 2010 and October 2011 with 306 Angolan and 301 Nigerian parents in The Netherlands as part of the Transnational Child Raising Arrangements between Africa and Europe project. As no baseline survey exists making a random sampling procedure impracticable, various strategies were employed to reach as diverse a population as possible. Interviewers were employed from different ethnic groups and social strata to access different types of migrants. Furthermore, different gateways were used into the various communities: churches, hometown organisations, personal contacts, city and government departments and snowballing.

Purposive sampling was used to have half the sample consist of parents with at least one child in the country of origin and half of parents with all children in The Netherlands. Furthermore, an equal sex ratio was sought. To be eligible for this study, respondents had to have spent at least one continuous year in The Netherlands, have children under the age of 21 and should have settled in The Netherlands at age 18 or older for Nigerians and 16 years or older for Angolans given that the latter often came at a young age as UAMs. One parent was randomly selected to be interviewed, in cases where both parents were living in The Netherlands.

\subsubsection{Dependent variables}

Subjective well-being generally refers to how people evaluate their lives and is a measure of their quality of life (Diener et al., 2003). The analysis here uses four distinct measures of well-being to capture the multi-dimensional nature of the concept: self-assessed health, happiness, life-satisfaction and mental health. For the first three measures, respondents were asked to indicate on a scale from 1 to 5 how they rate their health, how satisfied they are with their lives and how happy they consider themselves. Higher scores indicate greater well-being. These measures have been used and validated in previous well-being research (Abdel-Khalek, 2006; Larsen, Diener, \& Emmons, 1985; Pavot \& Diener, 2008; Stack \& Eshleman, 1998).

Mental health status is measured with the 12-item General Health Questionnaire (GHQ) developed by Goldberg (1992). The GHQ-12 consists of 12 questions on anxiety 
and psychological distress, for which respondents have to indicate on a 4-point scale if they have experienced such feelings recently. The answers to these questions are taken together to form the GHQ measure as prescribed by Goldberg, forming a scale from 1 to 12. The GHQ-12 was chosen because it is relatively brief, has been used and verified in different countries, including Nigeria and The Netherlands, and has been translated and validated in over 30 languages including Dutch, English and Portuguese, which are the languages used in the survey (Goldberg et al., 1997; Gureje, 1991). Additionally, the appropriateness of using the GHQ-12 as a measure of mental health was examined for the specific populations of this study. The internal reliability of the GHQ measure is high with an alpha value of 0.93 for Nigerians and 0.94 for Angolans. Furthermore, an exploratory factor analysis confirmed that the 12 items of the GHQ load on one factor only, accounting for 92 percent of the variance in the Nigerian and 99 percent of variance in the Angolan sample. The GHQ measure is treated as continuous in the analyses with higher values indicating lower mental health status.

\subsubsection{Independent variable}

The variable of interest indicates whether respondents are in a transnational family, i.e., whether they have at least one child under the age of 21 living in the country of origin. We refer to these parents as transnational parents. Respondents in the reference group (non-transnational) have all children living in The Netherlands.

\subsubsection{Control variables}

Based on the migrant well-being literature reported above, the following control variables are included. Socio-demographic variables include age of the respondent, sex and marital status. Socio-economic status is measured through three variables: education measured by the highest completed educational level consisting of 11 categories ranging from no schooling (1) to finished university (11); having enough money to live on from day-to-day consisting of two categories (1) did not have enough money at times or not at all and (2) had enough money from day-to-day; economic activity measured as economically active (respondents currently employed), inactive (homemaker, retired, student and thus not in need of or not actively searching for a job) and unemployed.

Variables to reflect migration characteristics include years in The Netherlands, legal status, and language proficiency. Legal status is a binary variable with undocumented and documented as categories. Dutch language proficiency is measured by whether respondents experienced difficulties communicating in Dutch on a scale from (0) have not experienced, (1) not at all stressful to (4) extremely stressful.

To assess the social networks of respondents we use two measures: namely the number of family members (including extended family relationships) in The Netherlands 
and the number of friends in The Netherlands. As the variable is positively skewed, a logarithmic form is used to create a normally distributed variable.

Based on previous studies on transnational family life two additional variables are included: whether the respondent has at least one child under 8 years of age and the quality of the parent-child relationship. Six response options for the latter ranged from $1=$ always open/warm to $6=$ never open/warm. To account for skewness in this variable, we created a binary variable with the last three responses indicating a poor relationship and the former three indicating a good relationship. Respondents were coded as having a poor parent-child relationship when they indicated this for at least one child, as a poor relationship with even just one child can affect a parent's well-being.

Interaction terms are included in separate models to explore whether the effect of low socio-economic and undocumented status, gender and the quality of the parentchild relationship differ according to a parent's transnational status as the transnational family literature suggests. For example, by interacting sex with transnational family status, we can explore whether transnational mothers are impacted by separation more severely than transnational fathers. Only significant interaction terms are displayed.

\subsubsection{Socio-demographic characteristics}

Table 5.1 displays descriptive sample statistics for Nigerians and Angolans separately. Our sampling resulted in 125 Nigerian and 129 Angolan transnational parents and 161 Nigerian and 160 Angolan non-transnational parents. Most respondents are married or in a relationship, have received vocational training or higher, are economically active, are documented, report a good relationship with their children, and have some friends and family living in The Netherlands. While approximately half of the overall sample consists of female respondents, only approximately 30 percent of transnational parents are female.

There are some noteworthy differences between Angolans and Nigerians reflecting their different migration histories. First, Angolans have, on average, been in The Netherlands for a longer period of time because they came as asylum seekers from the beginning of the civil war in Angola. Second, reflecting general characteristics of Nigerians (Heelsum, 2005; OECD, 2008), in our sample Nigerians are highly educated with over half having obtained a university degree. Most Angolans have obtained a degree in The Netherlands, especially in vocational training, again reflecting their longer time in The Netherlands and the fact that many came quite young, as unaccompanied minors. As a result, Dutch language proficiency is higher amongst Angolans than Nigerians in our sample. Third, while 16 percent of the total Nigerian sample and 27 percent of the Nigerian transnational parents is undocumented at the time of the survey, only 3 percent of Angolans is undocumented because many obtained refugee status and, thereafter, also Dutch citizenship. 
Table 5.1. Descriptive statistics of the control variables

\begin{tabular}{|c|c|c|c|c|c|c|c|c|}
\hline & \multicolumn{4}{|c|}{ Nigerians } & \multicolumn{4}{|c|}{ Angolans } \\
\hline & \multicolumn{2}{|c|}{$\begin{array}{l}\text { Transnational } \\
\text { parent }(\mathrm{N}=132)\end{array}$} & \multicolumn{2}{|c|}{$\begin{array}{l}\text { Non-transn. } \\
\text { parent }(\mathrm{N}=165)\end{array}$} & \multicolumn{2}{|c|}{$\begin{array}{l}\text { Transnational } \\
\text { parent }(\mathrm{N}=139)\end{array}$} & \multicolumn{2}{|c|}{$\begin{array}{l}\text { Non-transn. } \\
\text { parent }(\mathrm{N}=167)\end{array}$} \\
\hline & Mean & Std. Dev. & Mean & Std. Dev. & Mean & Std. Dev. & Mean & Std. Dev. \\
\hline Age (26-63) & 39.61 & 5.85 & 37.99 & 6.18 & 34.45 & 5.84 & 33.53 & 6.73 \\
\hline $\operatorname{Sex}(0 / 1)^{\mathrm{a}}$ & 0.29 & 0.45 & 0.52 & 0.50 & 0.30 & 0.46 & 0.62 & 0.49 \\
\hline Marital status $(0 / 1)^{\mathrm{b}}$ & 0.16 & 0.37 & 0.13 & 0.33 & 0.18 & 0.39 & 0.16 & 0.36 \\
\hline Education (1-11) & 8.77 & 2.34 & 8.92 & 2.33 & 7.39 & 1.90 & 7.13 & 2.37 \\
\hline Enough money $(0 / 1)^{c}$ & 0.33 & 0.47 & 0.62 & 0.49 & 0.64 & 0.49 & 0.63 & 0.48 \\
\hline Economically active $(0 / 1)$ & 0.54 & 0.50 & 0.72 & 0.45 & 0.90 & 0.30 & 0.72 & 0.45 \\
\hline Economically inactive $(0 / 1)$ & 0.19 & 0.39 & 0.11 & 0.31 & 0.04 & 0.20 & 0.27 & 0.45 \\
\hline Unemployed $(0 / 1)$ & 0.27 & 0.45 & 0.18 & 0.38 & 0.05 & 0.22 & 0.01 & 0.11 \\
\hline Years in NL (1-32) & 6.36 & 4.49 & 10.22 & 6.11 & 14.54 & 4.59 & 14.30 & 4.28 \\
\hline Legal status $(0 / 1)^{\mathrm{d}}$ & 0.27 & 0.45 & 0.07 & 0.26 & 0.01 & 0.12 & 0.01 & 0.08 \\
\hline Number of friends NL (0-294) & 15.48 & 25.34 & 13.82 & 25.38 & 24.48 & 36.82 & 34.35 & 39.56 \\
\hline Amount family NL (0-101) & 0.73 & 1.54 & 1.56 & 2.92 & 5.74 & 10.87 & 5.01 & 12.92 \\
\hline Language proficiency $(0-4)$ & 2.38 & 1.13 & 2.19 & 1.29 & 1.44 & 0.97 & 1.34 & 1.11 \\
\hline Child $<8$ years of age $(0 / 1)^{\mathrm{e}}$ & 0.52 & 0.50 & 0.67 & 0.47 & 0.73 & 0.44 & 0.79 & 0.41 \\
\hline Parent-child relation $(0 / 1)^{\mathrm{f}}$ & 0.20 & 0.40 & 0.06 & 0.24 & 0.40 & 0.49 & 0.09 & 0.29 \\
\hline
\end{tabular}

Source: TCRAf-Eu parent survey Netherlands, 2010-2011.

Notes: References include ${ }^{\mathrm{a}}$ Male; ${ }^{\mathrm{b}}$ Married/in a relationship; ${ }^{\mathrm{c}}$ Do not have enough money to live on a day-today basis; ${ }^{\mathrm{d}}$ Documented; ${ }^{\mathrm{e}}$ Respondent does not have children under 8 years old; ${ }^{\mathrm{f}}$ Good relation child.

\subsubsection{Analytical strategy}

The analysis is conducted in two stages. First, we test whether transnational parents, on average, report lower subjective well-being than non-transnational parents with independent two sample t-tests. Second, ordinary least squares (OLS) regressions with robust standard errors are performed to assess whether differences still hold while controlling for individual migrant characteristics. Separate analyses are performed per migrant group as people from different cultures may assess their well-being differently and the effect of social desirability on answers can differ (Diener et al., 2003). Moreover, because of different characteristics of the two groups, specific variables may have different effects in the two groups, which would be hidden by running a single model with both groups together. Each cluster of variables was added in a stepwise fashion to ascertain the impact of each group on the dependent variable. Due to space limitations, only full models are presented. A separate model is run for each of the subjective wellbeing measures. Additional models estimated interactions between being in a transnational family and gender, documented status, socio-economic status and parent-child relationships, to see whether these factors are equally important for the well-being of 
transnational and non-transnational parents. Only significant interaction effects are displayed. Finally, as the data are cross-sectional, we note associations but do not make causal claims.

The models are specified equally for the two migrant populations with the exception of legal status and economic activity. Both variables were omitted in the Angolan models due to the low numbers of respondents who are undocumented (3) and unemployed (9).

\section{$5.5 \quad$ Results}

Table 5.2 shows the differences in subjective well-being between transnational and nontransnational parents by comparing the means of the subjective well-being scales used. Well-being is lowest among transnational parents. Minor differences are found between the two migrant groups for the different indicators of subjective well-being. Angolans report significantly lower mental health status than Nigerians and only Angolan, and not Nigerian, transnational parents report being healthy less often. The general picture that emerges is consistent with transnational family studies, which indicate that parentchild separation lowers parents' well-being, and with research indicating that refugees generally report higher levels of psychological distress (Suarez-Orozco et al., 2002; Vega \& Rumbaut, 1991).

Table 5.2. Descriptive statistics of subjective well-being

\begin{tabular}{lcccccr}
\hline & \multicolumn{2}{c}{ Nigerians } & & \multicolumn{2}{c}{ Angolans } \\
\cline { 2 - 3 } & $\begin{array}{c}\text { Non-transnational } \\
\text { parent }(\mathrm{N}=161)\end{array}$ & $\begin{array}{c}\text { Transnational parent } \\
(\mathrm{N}=132)\end{array}$ & & $\begin{array}{c}\text { Non-transnational } \\
\text { parent }(\mathrm{N}=167)\end{array}$ & $\begin{array}{c}\text { Transnational } \\
\text { parent }(\mathrm{N}=139)\end{array}$ \\
\hline Health (1-5) & $4.17(0.74)$ & $4.13(0.74)$ & & $4.20(0.86)$ & $4.00(0.88)^{*}$ \\
Mental health (1-12) & $1.19(2.58)$ & $2.51(3.45) * * *$ & & $2.54(3.57)$ & & $4.40(4.22)^{* * *}$ \\
Happiness (1-5) & $4.16(0.74)$ & $3.76(1.00) * * *$ & & $4.31(0.88)$ & $3.80(1.05)^{* * *}$ \\
Life satisfaction (1-5) & $4.10(0.77)$ & $3.77(0.98) * * *$ & & $4.10(0.77)$ & $3.77(0.98)^{* *}$ \\
\hline
\end{tabular}

Source: TCRAf-Eu parent survey Netherlands, 2010-2011.

Notes: Independent sample t-test. Means presented with standard deviations in parentheses. Higher scores indicate higher levels of happiness, health and life satisfaction, but lower levels of mental health.

${ }^{\star} \mathrm{p}<0.05 ;{ }^{* *} \mathrm{p}<0.01 ;{ }^{* *} \mathrm{p}<0.001$.

Table 5.3 and Table 5.4 display the results of the OLS regressions for Nigerians and Angolans respectively. When controlling for individual characteristics, some of the associations between transnational migrant parents and subjective well-being disappear. Again, important differences are found between Angolans and Nigerians. Each measure of well-being is discussed separately below. As the primary purpose of this study is to 


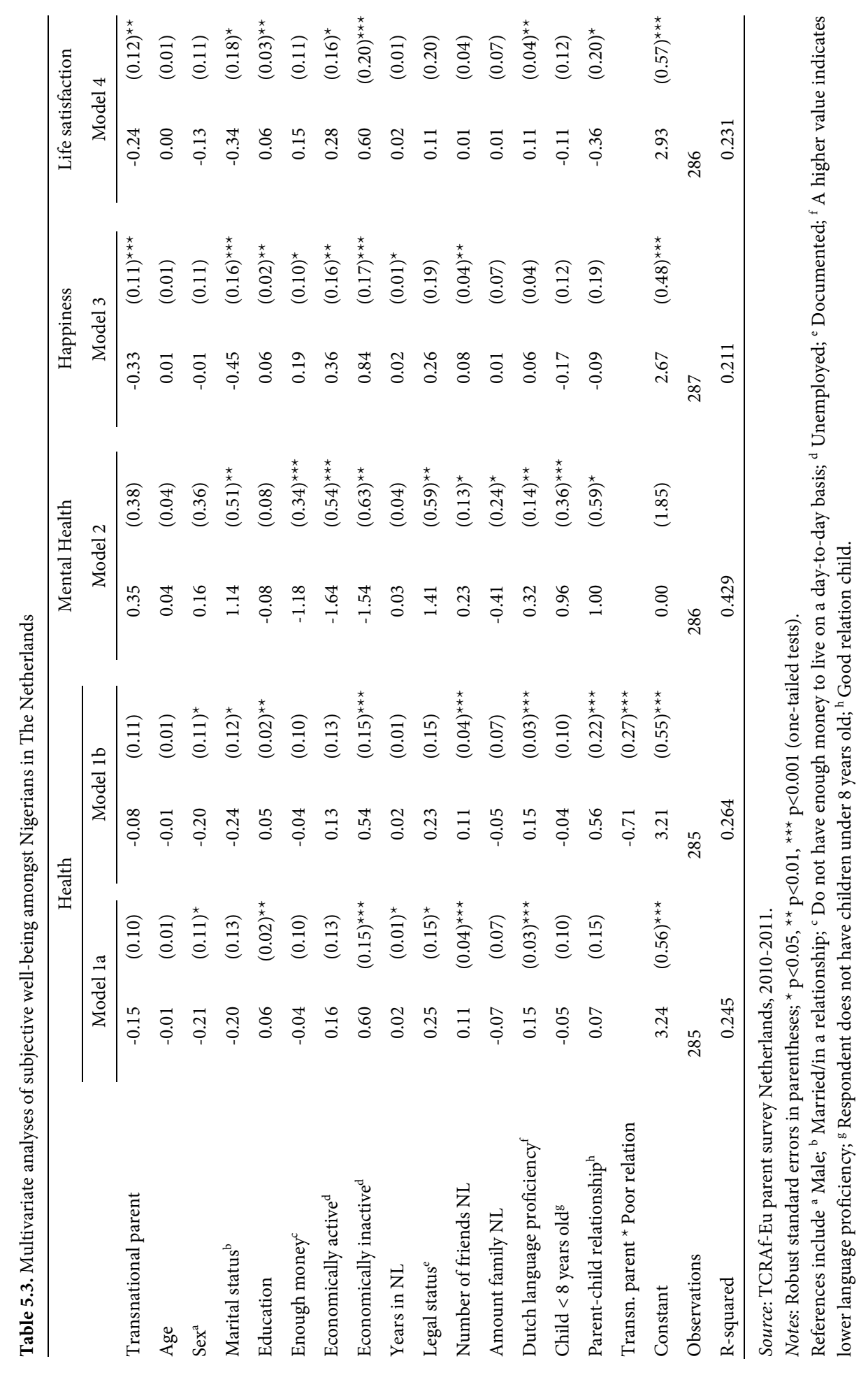




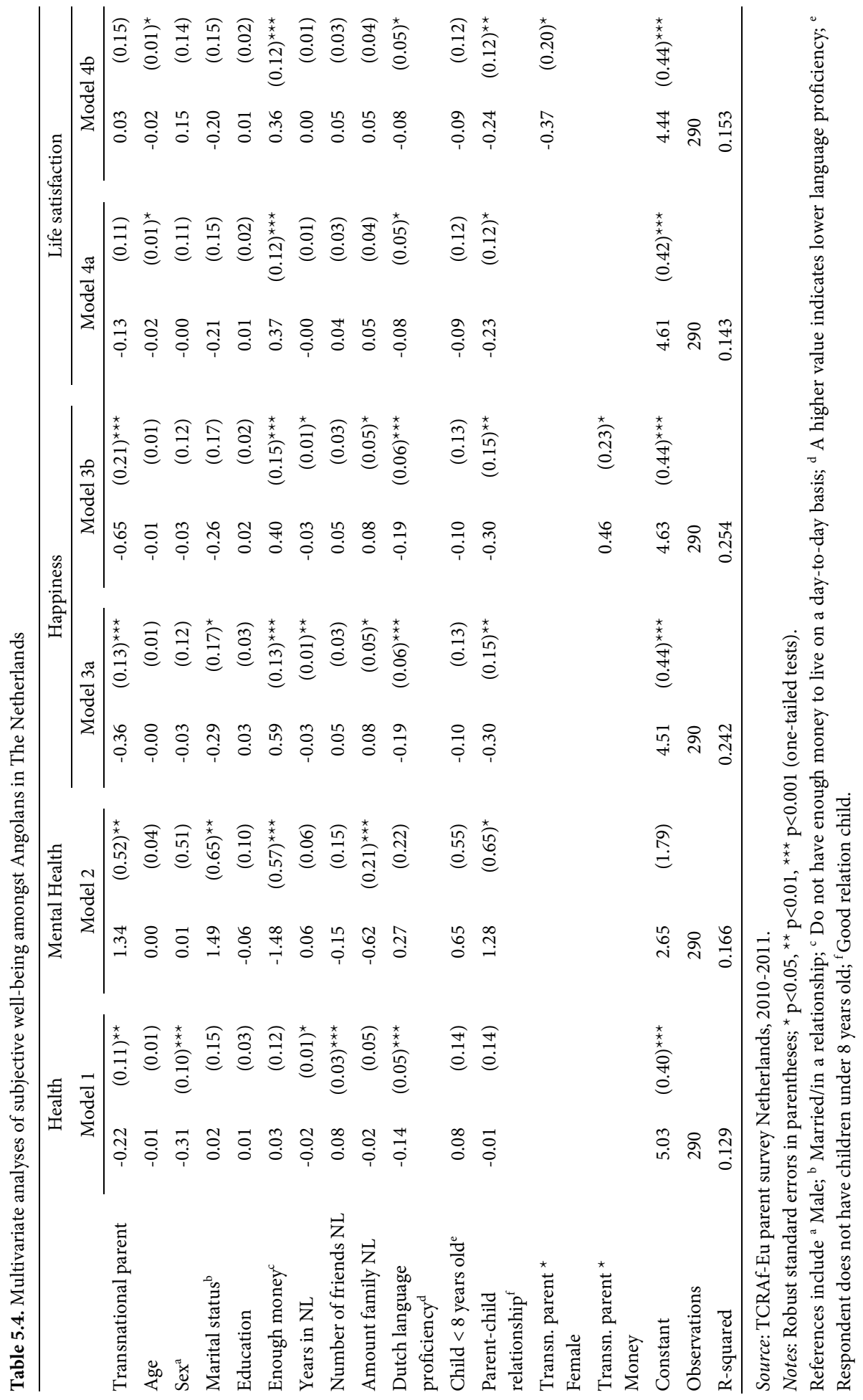


investigate the association between transnational family life and well-being, control variables are only discussed if they can help explain the associations found in Table 5.2.

\subsubsection{Health}

The bivariate analyses show that there are only significant differences in health status amongst the Angolan parents. As shown in Table 5.4 model 1, adding control variables did not eliminate these differences. Displayed in Table 5.3 models 1a and 1b, we find furthermore that for Nigerians a poor relationship with children is negatively associated with health but that this effect is stronger for parents who live with their children in The Netherlands than for transnational parents.

\subsubsection{Mental health status}

Initially, both Nigerian and Angolan transnational parents reported lower mental health status, but as displayed in Table 5.3 model 2, this effect disappears for Nigerians when control variables are introduced. A stepwise regression (only final results presented) reveals that legal and wealth statuses mediate the relation between family separation and mental health for Nigerians: when both indicators are included the relation between transnational parenting and mental health status ceases to be significant. This result indicates that separation itself is not a direct cause of emotional distress for Nigerians, but it is often paired with lower socio-economic and undocumented status, which consequently results in lower mental health.

\subsubsection{Happiness}

As shown in models 3, transnational parents are less happy than non-transnational parents, even while controlling for other factors. Single parents and parents who report not having enough money on a day-to-day basis display lower levels of happiness. This latter relation is stronger for transnational parents than non-transnational parents in the Angolan sample, as indicated by the significant and positive interaction term in Table 5.4 model 3b.

\subsubsection{Life satisfaction}

Although transnational parents are initially less satisfied with life, this relation ceases to be significant for Angolans when including the parent-child relationship (Table 5.4 model 4a). This suggests that Angolan transnational parents feel less satisfied with life when their relationships with their children are poor. Though a poor parent-child relationship is also associated with low life satisfaction in the Nigerian sample, being a transnational parent remains significantly related to life satisfaction. Finally, although 
the main effects were not significant, the interaction between being a transnational parent and being female is significant, as shown in Table 5.4 model $4 \mathrm{~b}$. A separate analysis (not shown) indicates that the association between being a transnational parent and life satisfaction is significant for mothers but not for fathers.

\subsection{Discussion}

This study is one of the first multivariate analyses exploring the relationship between migrant well-being and transnational family formations. As such, it gives nuance to general findings from qualitative transnational family studies that emphasise a negative and direct relationship between low parental well-being and not living with one's children. We find three important nuances, which we will discuss in detail below. First, it is important to specify different dimensions of well-being as these can be differently associated with transnational family life. Second, controlling for other factors that can also affect migrant parent well-being is important as these factors reveal that we can not study the effects of transnational parenting in isolation. Third, a comparative dimension helps to highlight that sending and receiving country contexts can affect the well-being of parents in transnational families.

Different measures of subjective well-being are associated with different levels of well-being, pointing to the importance of taking various dimensions into account when studying well-being. The analyses indicate that while both Nigerian and Angolan transnational parents are less happy than non-transnational parents, these differences in subjective well-being are not necessarily found for other measures of well-being after controlling for individual characteristics. Although Nigerian transnational parents report lower life satisfaction, Angolan transnational parents report weaker physical and mental health.

Second, socioeconomic status and undocumented status stand out in explaining the issue at hand. Undocumented status is often related to low socio-economic status but also prohibits physical contact and family reunification, leading to increased stress and poor emotional well-being (Horton 2009). Dutch family reunification policy allows documented migrants with a minimum level of stable income to bring their children to The Netherlands. This especially impacts Nigerians who are undocumented. Angolans also experience difficulties with family reunification, even if they are for the most part documented because they mainly entered The Netherlands as refugees. Refugees can only bring children over within the first three months of arrival and only when the family came into being before, and not during, migration. After this period, similar conditions apply as for labour migrants (Defence for children \& Vluchtelingenwerk Nederland 2012). These factors affect the type of migrant likely to be situated in a transnational family and hence could explain why, in the first instance, we find that parent-child separation is related to poor mental health but not when controlling for 
legal and wealth status. In the case of Angolans, we also find that transnational family life is not directly associated with low life satisfaction, but rather that poor parent-child relationships mediate this association.

Generally, we do not find many significant interaction terms suggesting that characteristics associated with migrant well-being have the same effects for transnational as for non-transnational parents. However, three interaction terms are found to be significant. First, Angolan transnational mothers are significantly less satisfied with their lives in comparison to non-transnational mothers, but this difference is not found for fathers. In other words, with regard to life-satisfaction Angolan mothers seem to be especially impacted by transnational separation. Yet, unexpectedly no other differences were found for transnational mothers and fathers, suggesting that while the normative expectations and experiences of mothers and fathers might be different, as suggested by the qualitative transnational families literature, in general these do not result in different well-being outcomes. Second, the association between having enough money to live on from day-to-day and happiness is stronger for Angolan transnational parents, indicating that socio-economic status is especially important for happiness of Angolan transnational parents. Third, while transnational parents more often indicate a poor relationship with their child, the association between a poor parent-child relationship and poorer health is only found for Nigerian non-transnational parents.

Third, important differences are found between the two migrant groups while controlling for other factors, indicating that migrant groups are heterogeneous. For Nigerians, being a transnational parent is only related to life satisfaction and happiness, whereas for Angolans, mental health status, health and happiness are related to being a transnational parent. Furthermore, Angolans generally report a significantly lower subjective well-being than Nigerians, possibly as a consequence of their former refugee status. Refugees commonly report higher levels of psychological distress and trauma because they had to flee a country at war and had little control over their migration (Vega and Rumbaut 1991). As a result of war, a significant number of Angolans have been victims of violence or have left family and friends in an instable and destructive post-war context. This trauma and distress can increase the effect that the transnational parent-child separation has on the subjective well-being of Angolan migrant parents and can explain why transnational family life is associated with lower mental and general health for Angolans while it is not for Nigerians. Measures of mental and general health capture more severe states of well-being than satisfaction and happiness, as health and the questions asked in the GHQ-12 relate to more tangible complaints that can affect daily life, rather than general states such as happiness or satisfaction.

Several limitations should be considered. First, causal inferences cannot be drawn because of the cross-sectional nature of the data. The association between socioeconomic status and well-being may go both ways: low income may cause low subjective well-being and low well-being may cause people to perform less well at their jobs, 
possibly leading to low income. However, with specific reference to the main variable of interest, i.e., someone is a transnational parent, there is less reason to believe that reverse causation plays a role. It is unlikely and we can find no evidence to substantiate the claim that parents with low levels of subjective well-being before migration are more likely to leave their children in the country of origin. Second, although the GHQ-12 has been widely used and tested, it has not been validated amongst Angolans. However, a factor analysis conducted in this study indicated high reliability and validity of the measure. Third, the measures of health and well-being are subjective and assessments have been shown to differ per culture and to be prone to reporting bias (Jolivet et al. 2012; Diener, Oishi, and Lucas 2003). As we are interested in the mechanisms underlying the association between transnational parenting and well-being and not in differences in values between the groups, this does not undermine our findings. Finally, although we have tried to use different gateways to reach respondents, our sampling strategy might have led to some sampling bias.

Notwithstanding its limitations, this research has made several contributions to the study of the effects of migration on transnational family life. First, it takes a transnational approach in studying migrant well-being. Literature on migrant well-being has generally ignored migrants' family life that extends across national borders by focusing on individual characteristics of migrants as related to their stay in the host country. However, migrants remain tied to their home country in multiple ways, which has been enhanced by new means of communication and lower-cost travel. Consequently, despite large geographical distances, events in the country of origin can affect the daily life of migrants in the host country. This especially pertains to transnational families in which childcare is arranged transnationally. Transnational family literature has argued that these arrangements can affect the lives and well-being of migrants in the host country. As such, it is important to take migrants' transnational family formations into account when studying migrant well-being outcomes. Our study is a first step in this direction. Future research can expand on this and include longitudinal studies.

Second, the paper contributes to transnational family literature by investigating different dimensions of well-being in a quantitative way to control for the effects of other possible influential factors. While qualitative studies on transnational family life have indicated that transnational parent-child separation leads to loneliness, shame, guilt and depression amongst migrant parents, the exact dimension of well-being that has been investigated remains vaguely defined. Conceptualisations differ per study and population, making comparisons difficult. Our results show that being a transnational parent is associated with certain measures of well-being and not with others, signalling the importance of parsing dimensions of well-being as well as the need to include various measures to gain a more complete picture of migrant well-being. This finding is in accordance with other studies that found disparities in migrant health depending on how the outcome was measured (e.g. Sudano and Baker 2006; Jolivet et al. 2012). 
A final contribution of the paper is methodological, addressing the need for the use of comparison groups of non-transnational migrant families in the assessment of the effects of transnational family life. Without a comparison group, it is difficult to assess whether transnational parents experience additional emotional distress because of the transnational parent-child separation. Our study has indicated that transnational family life is not necessarily related to low levels of subjective well-being but can be explained by other factors. As such, it adds nuance to qualitative transnational family studies and psychology studies based on clinical data that suggest that transnational family life has a detrimental effect on parental well-being.

A comparison of two migrant groups in the same destination country has shown that the context of migration can significantly impact the associations between being in a transnational family and lower subjective well-being. Migrant groups are heterogeneous and generalisations across migrants groups are thus not possible and lead to incorrect statements. The reasons that spurred migration as well as the context in which migrants are received in the host country are related to the well-being of migrants but also to the effects that transnational family separation has. 

CHAPTER 6.

Job outcomes of transnational parents 



\subsection{Introduction}

After several decades of migration research that was focussed on the migration of intact family units and families being associated with the locus of residence, family migration scholars have turned their focus to more complex family arrangements resulting from international migration (Cooke, 2008; Hardill, 2004; Mazzucato \& Schans, 2011). Throughout history people have lived transnational lives with nuclear family members located in multiple nation states. Today, the number of transnational families seems to be on the rise, with both men and women migrating without their families. Some argue that this is the result of global capitalism, global inequalities and the current international division of labour in which individuals are encouraged and at times forced to migrate to ensure the family's economic well-being (Dreby, 2007; Schmalzbauer, 2004). Especially migrants from developing countries tend to take up low-wage service labour that is needed in industrialized countries, while leaving non-productive family members, such as children, behind (Hondagneu-Sotelo \& Avila, 1997; Parreñas, 2001; Schmalzbauer, 2004). Restrictive immigration policies, high migration costs and difficult living and working conditions in the host country provide disincentives for families to migrate together. Yet some parents prefer to leave their children in their origin country to grow up in familiar cultural environments, supported by extended family (Coe, 2008).

Transnational family scholars have argued that while transnational parenting can provide more financial security to their families, transnational parent-child separation can also have negative consequences for parents and children. It has for example been found that parents and children are negatively affected in their emotional well-being and health, and children in their educational performance (Dreby, 2007; Horton, 2009; Parreñas, 2005; Suarez-Orozco et al., 2002; Wen \& Lin, 2012; Zentgraf \& Chinchilla, 2012). Yet while family sociology and transnational migration studies have investigated the emotional consequences of transnational family life for children and their parents, other important consequences for parents' lives are less researched. One aspect that has been neglected is how being in a transnational family affects parents' labour market outcomes, especially since the economic returns of this labour are an important part of transnational parenting (Zentgraf \& Chinchilla, 2012). The ability to send remittances and provide for the family is the main reason why some parents migrate in the first place and remittances are found to be of major importance for maintaining transnational family relations (Dreby, 2006; Dreby \& Adkins, 2010; Zentgraf \& Chinchilla, 2012). Studies from organizational psychology lead us to believe that there are various ways in which transnational parenting can be related to job outcomes. This study therefore aims to contribute to transnational family studies by studying the association between transnational parents' work and family lives. 
Working-class migrants often face downward mobility and economic strain when living in the host country (Portes \& Rumbaut, 2001). Upon arrival opportunities of finding work are often only available in certain low-paid sectors such as cleaning, if at all. Not speaking the new language, qualifications not being recognized, not having a work permit and discrimination are compounding factors (Spitzer et al., 2003; Wright, 2011). The insecure but also inflexible employments migrants often find themselves in can be extra demanding and stressful when a migrant also has caregiving responsibilities, draining energy and time. A lack of kin-support and the reluctance of migrants of nonWestern origin to use expensive formal childcare services only exacerbate the strain these migrants feel (Spitzer et al., 2003). This stress can result in poor job performance. On the other hand, child raising arrangements in which care is arranged transnationally do not necessarily lift caregiving responsibilities and can also be a cause of stress. Transnational family studies have argued that transnational separation can lead to lower levels of well-being for parents. This in turn can affect concentration and performance at the job.

Job outcomes of transnational parents are investigated with data collected on Nigerians and Angolans living in The Netherlands by comparing migrant parents whose children live in the home country, with parents whose children live with them, in The Netherlands. Comparing two migrant groups who face different structural conditions in The Netherlands allows investigating how these conditions may influence job performance through the effects they have on migrants' work-family sphere. Research has found that structural conditions such as legal and employment status affect how people engage in transnational child raising arrangements (Bernhard et al., 2009; Grzywacz et al., 2007; Haagsman, Mazzucato, \& Dito, 2013).

\subsection{Work and family life}

Significant research attention has been given to the difficulties people face balancing work and family life and on factors leading to favourable job outcomes. Yet, no such research has been conducted amongst families in which care is arranged transnationally. Based on two bodies of literature - work-family conflict and the happy productive worker thesis - a theoretical framework is proposed to investigate the effects transnational parent-child separation has on job outcomes of migrant parents. This literature has mainly studied job outcomes by looking at job performance while the current study concentrates on job instability and absenteeism. Although the particular outcomes are thus slightly different, we can still draw important lessons from this literature.

\subsubsection{Work-family conflict}

Although not particularly focused on migrants, occupational stress research on workfamily interactions has shown that both work and family life are negatively impacted 
when demands of one domain affect the other (Adams, King, \& King, 1996; Frone, Russell, \& Cooper, 1992; Lapierre \& Allen, 2006). Workers with child care responsibilities, for example, experience difficulties with juggling family and work, which can result in conflict when demands of participation in the family domain are incompatible with demands in the work domain and vice versa (Adams et al., 1996). A longstanding and extensive literature has consistently shown that work and family life are intrinsically and reciprocally related. Higher levels of work interfering with family are related to burnout and health complaints (Bacharach, Bamberger, \& Sharon, 1991; Burke, 1988; Thomas \& Ganster, 1995). Conversely, family-to-work conflict is also associated with lower job satisfaction, less organizational commitment and more distress at the job (Frone et al., 1992; Wiley, 1987).

The extent to which family life creates strain on work and vice-versa is related to the nature of family, care and work arrangements and structural and social demands of the family (Grzywacz et al., 2007; Kossek, Jason, \& Noe, 2001). A worker whose spouse stays at home to take care of the children is less likely to experience family-to-work conflict than a family of dual earners or a single parent with preschool-aged children (Adams et al., 1996). Especially family support is of importance as it relieves the employee of family-related responsibilities and offers the employee more time and energy to fulfil responsibilities at work (Lapierre \& Allen, 2006). If working parents have family to help with caregiving when children are sick, they are less likely to experience workfamily conflict (Kossek, 1990). Ethnicity, gender, age, marital status, social class and occupation are also important (Voydanoff, 2002). The presence of children, moreover, is more likely to affect job participation of mothers than that of fathers as they are often seen as the primary caregiver (Greenhaus \& Parasuraman, 1999).

Caregiving decisions are only linked to lower levels of well-being and increased conflict when they do not fit the family or work environment. For example, research has shown that the more one is devoted to caregiving the less one is able to commit to an organization, which can affect job performance (Thompson, Beauvais, \& Lyness, 1999). Hence, well-being and job outcomes are impacted negatively when the carer has to make sacrifices in one role to fulfil another. However, what appears to be most important for the perceptions of work-family conflict are not so much the type of care arrangement used but the satisfaction the parent has with the caregiving arrangements (Kossek et al., 2001).

In transnational families the direct provision of care is not given by the migrant parent in the host country but by a caregiver in the country of origin. Based on the work-family conflict thesis, it can therefore be hypothesized that migrant parents whose children are in the country of origin, experience less family-to-work conflict than parents who live with their children in the host country and this leads to favourable job outcomes, as measured by job stability and attendance (Hypothesis 1). 


\subsubsection{Happy productive worker thesis}

Research on well-being has consistently shown that happiness is related to various forms of success. Success leads to happiness but longitudinal research also shows that happiness can predict success (Lyubomirsky, King, \& Diener, 2005). People who generally have positive emotions are more sensitive to rewards in their environment and are more likely to move towards rather than shun rewarding situations (Lyubomirsky et al., 2005). Therefore, they are more optimistic about future events and are more proactive, resilient and less prone to stress symptoms (Wright, Cropanzano, \& Bonett, 2007). People who have negative emotions, instead, become more disengaged with the world and are less optimistic that their hard work will lead to success (Wright, Cropanzano, Denney, \& Moline, 2002). Positive and negative affect or happiness can be ingrained in the personality of an individual, but may also be rooted in the person's current life circumstances or a combination of these (Lyubomirsky et al., 2005).

Based on the above, we can assume that "satisfied and psychologically well employees are more likely than those less satisfied and psychologically well to have the resources necessary to foster and facilitate increased levels of job performance" (Wright et al., 2007, p. 97, p. 97). In other words, happiness stimulates activity and workinvolvement. This is captured in the happy productive worker thesis developed by some organizational theorists, which posits that workers who are happy perform better at their job than do employees who are unhappy (Wright et al., 2007; Wright et al., 2002). Although this thesis was received with scepticism at first, a small but growing body of empirical research has found support for the happy productive worker thesis. Evidence from cross-sectional but also longitudinal research corroborate that happy workers enjoy multiple advantages in comparison to unhappy workers, and most importantly perform better at their job. Staw, Sutton, and Pelled (1994) found that employees who had positive emotions had greater pay 18 months later, more social support on the job and received better performance evaluations. Similarly, studies by Wright, Cropanzano and colleagues using various methods and research designs have found that well-being leads to better job performance even when controlling for age, gender, education and tenure at the organization (e.g. Cropanzano \& Wright, 1999, 2001; Wright et al., 2007; Wright et al., 2002; Wright \& Staw, 1999).

People with high levels of subjective well-being are more likely to secure job interviews, appear to secure better jobs, show superior performance and productivity, are more efficient, can handle managerial jobs better, are less likely to show counterproductive workplace behaviour, get more support from co-workers and are more satisfied with their job (Lyubomirsky et al., 2005). Happy people receive good performance evaluations and are satisfied with their jobs and consequently, they are less often absent from work, less likely to want to quit and less likely to experience job burnout or withdrawal (Donovan, 2000; Lyubomirsky et al., 2005; Wright \& Cropanzano, 1998). Finally, 
gender, education, ethnicity, wealth, marriage and family support are important resources that can act as coping mechanisms.

The above body of knowledge has implications for transnational families. Qualitative transnational migration studies since the 2000's have indicated that when migrant parents live separated from their children they are emotionally affected. If they do not have regular physical contact with their children, parents experience difficulties in maintaining strong emotional bonds with their children. This loss of intimacy and the fact that parents long to be with their children can lead to stress, feelings of guilt, loneliness, and even to depression (Aranda, 2003; Hondagneu-Sotelo \& Avila, 1997; Horton, 2009; Parreñas, 2001; Schmalzbauer, 2004). These qualitative findings are partly corroborated by a larger scale study which shows that parents who live separated from their children generally experience lower subjective well-being than parents who live with their children (Haagsman et al., 2013). Hence, bringing these two bodies of literature together, we can posit the opposite hypothesis than the one mentioned above: migrant parents whose children live in the country of origin will have unfavourable job outcomes, as measured by job instability and absenteeism, in comparison to migrant parents who live with their children in the host country due to their lower subjective well-being (Hypothesis 2).

In the remainder of this paper, we test these two contradictory hypotheses. Before doing so, we give a short description of the two groups under study.

\subsection{Migration context}

This paper draws on data collected amongst Angolan and Nigerian migrant parents in The Netherlands, two non-Western countries of origin. The majority of the evidence for the happy productive worker thesis and work-family conflict, however, comes from Westernized industrialized countries in which happiness is highly valued. Other cultures can hold different definitions of success (Lyubomirsky et al., 2005). Also, the extent to which and the way in which individuals experience work-family conflict is dependent on the broader socio-contextual circumstances and norms and values regarding work and family that are dominant in society (Grzywacz et al., 2007). For example, if hard work is valued and seen as necessary for family well-being and work-conflict is not interpreted as being stressful, it will less likely impact well-being, and job or family outcomes. Therefore, these theses might not apply to the same extent to two groups we study. Below the migration flows and the position the two groups hold in The Netherlands will be shortly described, as that might affect the outcomes of the analyses.

The main difference between the two groups under study is their migration trajectory to The Netherlands. Major migration from Angola began at the end of the 1990s as a result of a war that lasted until 2002. The Angolan migrants in The Netherlands originated predominantly from middle class families. The main reasons for migration 
were fear of being forced to fight in the army, the shortage of study and work opportunities in Angola and poverty (Wijk van, 2008). The Netherlands became a major destination country for Angolan asylum seekers because of its favourable asylum policies for this group of migrants at the time. Until 2002 it was relatively easy for Angolans to apply for asylum in The Netherlands, especially for Unaccompanied Asylum seeking Minors (UAM), i.e. asylum seekers under the age of 18 migrating without parents or other family members (Wijk van, 2007). Consequently, about half of the Angolan migrants in The Netherlands came as an UAM resulting in a rather young Angolan population. Resulting, at its peak in 2004, in over 12,000 Angolans residing in The Netherlands (Central Bureau for Statistics, 2013). Yet, as many Angolans have returned or were forced to return after the war ended in 2002 only around 8,500 Angolans remain in The Netherlands today (Central Bureau for Statistics, 2013).

Contrary to the Angolan population, Nigerian migration to The Netherlands has seen as steady increase. While in 1996 only 3,136 Nigerians were registered in The Netherlands today 11,466 Nigerians are residing in The Netherlands (Central Bureau for Statistics, 2013), making the Nigerians one of the fastest growing non-Western migrant groups in The Netherlands. In contrast to Angolans, Nigerians have a diversified migration trajectory. For example, in 201139 percent came through family reunification/ formation, 24 percent came for study purposes, 13 percent applied for asylum and 8 percent came through labour migration (Central Bureau for Statistics, 2013). Yet, these are the official numbers. As it is very hard to get a visa in Europe on the basis of labour, many use other ways such as through family formation or formation. Another common way for Nigerians to enter Europe is arriving on a tourist visa and overstay this (Carling, 2006). Although some of these migrants are able to obtain a residence permit through amnesties afterwards, many remain undocumented though exact numbers are unknown (Carling, 2006; Haas de, 2006).

As a result of the different migration trajectories to The Netherlands, Angolans and Nigerians hold a different position in Dutch society. Because these new migrant groups do not belong to the major migrant groups in The Netherlands, they are understudied and consequently there are no official data on their labour market participation. However, some general trends can be established based on our data and reports of others. First, the OECD (2008) reports that in 200055 percent of the Nigerians living in OECD countries had received tertiary education against 20 percent of the Angolans. This is also reflected in our data with the majority of respondents (52 percent) having obtained a university degree in comparison to 6 percent of the Angolan respondents. Yet, despite their higher education levels many Nigerians are found in low-paid and unskilled labour or are unemployed because their qualifications are not recognized, their Dutch language proficiency is low or because they do not have a working permit because of their undocumented status (Heelsum \& Hessels, 2006). Asylum seekers generally integrate more slowly into the labour market as they are not allowed to work when awaiting asylum and 
traumas can stand in the way of labour market participation (Heelsum, 2005). Nevertheless, Angolans have been in The Netherlands for a longer time and a large proportion was able to receive residence permits and is consequently legally residing in The Netherlands. Furthermore, UAMs received a Dutch education resulting in good Dutch language proficiency and a better position in the labour market than Nigerians. That is, the UAMs that came in before 2001. After 2001 less opportunities were given to UAMs. Nonetheless, our data indicate that Angolans have a relatively good position in the labour market, with only 1 percent being unemployed and 18 percent being in unskilled labour versus 22 and, 35 percent of Nigerians respectively.

These differences are important to take into account as socio-contextual circumstances, such as declining employment options, high unemployment rates and undocumented status, can affect the extent to which and the way in which individuals experience work-family conflict (Grzywacz et al., 2007). This is of particular importance to immigrants who specifically migrate to find employment and to financially provide for their families but are often situated in low-paid, dangerous and insecure labour positions where they have little opportunity to advance. For these immigrants "having any job is better for [their] family than having no job" (Grzywacz et al., 2007, p. 1121) and specific dissatisfactions can motivate people to work and pursue new directions. This applies specifically to the Nigerian population in The Netherlands who are often undocumented, unemployed and in unskilled labour.

Thus, even though these migrants are doing non-flexible and physical demanding work, family-to-work conflict is likely to be less pronounced in these groups as they tend to view work and family as more integrated. On the other hand, a loss of socioeconomic status, which immigrants often experience, can also lead to increased labour force participation which limits the time available for family and caregiving tasks, increasing work-family conflict. This is particularly the case for women who are expected to fulfil these caregiving tasks. Additionally, childcare is often problematic for recent immigrants as they have fewer kin to rely on (Spitzer et al., 2003), increasing possibilities of family-to-work conflict.

\subsection{Data \& analysis}

The present research draws on survey data collected in the TCRAf-Eu project investigating the functioning of transnational families amongst Angolan and Nigerian migrant parents in The Netherlands. The survey collected data from both transnational parents and parents who live with all their children in The Netherlands. Having both groups allows exploring specifically the effect of the separation. To be eligible for this study respondents had to have children under the age of 21 living in the host or origin country, have lived in The Netherlands for more than one year consecutively and had to be over 18 when coming to The Netherlands. Since many Angolans came to The Netherlands as 
UAM we decided to lower the age for this group to 16. Purposive sampling resulted in 132 transnational and 165 non-transnational Nigerian parents and 139 transnational and 167 non-transnational Angolan parents who mostly live in Amsterdam, The Hague and Rotterdam.

\subsubsection{Variable constructions}

Two job outcomes are studied: absenteeism and job stability. These are indicators that are easy to quantify and are more objective than other measures often used such as assessment by the employer (Pelled \& Xin, 1999). The first is measured by days absent in the past three months and the second by the number of times the migrant changed jobs while being in The Netherlands. Both are treated as continuous variables. The variable days absent is positively skewed, thus a logarithmic form is used to create a normally distributed variable. In some economic studies job mobility is considered a positive outcome as it can reflect change to better jobs, promotion and wage growth (Rosenfeld, 1992; Sicherman \& Galor, 1990). However, within the populations we study, changing jobs is a result of their insecure labour position and not because of career improvement. In fact, the data show that Angolans who were in high skilled labour and of higher socio-economic status have had significantly less job changes than those in unskilled and skilled labour and of low socio-economic status. These differences are not found for Nigerians, which might reflect the fact that a large proportion of Nigerians, both skilled and unskilled, are unemployed or have been unemployed for extended periods of time ${ }^{12}$.

To test the first part of the hypotheses concerning the mediating role of work-tofamily conflict, the following statements were used: 'Worrying about my children interferes with my ability to get things done at work' and 'I often miss work because I am worried about my children'. Respondents could answer on a five category Likertscale, from have not experienced (0), experienced but not at all stressful (1) to extremely stressful (4). These two items were combined in one scale and averaged, with higher scores indicating increased conflict. A reliability assessment shows that the scale is reliable for Angolans with a Cronbachs alpha of 0.74 , but not for Nigerians with a Cronbachs alpha of only 0.35 . There is just not enough variance in the Nigerian scale as the overall majority of Nigerians reported that their children do not interfere with their work (see Table 5.1). We will come back to this finding in the discussion.

The other mediating variable pertaining to the second set of hypotheses is happiness. Happiness was assessed using a 5-point scale ranging from not happy to very happy. To account for skewness, a binary variable was created by recoding the first three answer categories in unhappy (0) and the last two as happy (1). To analyse the robustness of the

\footnotetext{
${ }^{12}$ In the data 65 percent of the Nigerians have been unemployed while being in The Netherlands and 22 percent of the Nigerians in our data is currently unemployed. This is respectively 56 and 3 percent for Angolans.
} 
results, the same models were re-estimated with a measure of mental health status, namely the 12-item General Health Questionnaire (GHQ) developed by Goldberg (1992). Results found are virtually similar.

In examining a) the association between transnational parent's work and transnational family lives and b) the role of family-to-work conflict and subjective well-being, various commonly used controls are taken into account to avoid statistical confounds. Controls included age, sex, marital status, education, years in The Netherlands, socioeconomic status, legal status, social network, Dutch language proficiency and whether the respondent has young children (under eight years of age). Because only three Angolans are undocumented, we have excluded legal status in the Angolan analysis. Educational attainment was determined using an 11-point scale, ranging from (1) no schooling to (11) finished university. To capture socio-economic status a dummy variable is included on house ownership as earnings or other similar measures could lead to problems of endogeneity. House ownership is a more long-term and stable measure of socio-economic status. The social network of the respondent is divided in two variables, one measuring the number of family members in The Netherlands and the other measuring the number of friends living in The Netherlands. A log transformation is applied to correct for the skewed distribution of the social network variables. Finally, to assess Dutch language proficiency respondents were asked to indicate whether they had experienced difficulties communicating in the Dutch language, from (0) have not experienced, (1) not at all stressful to (4) extremely stressful. Hence, higher scores indicate more problems with speaking the Dutch language and higher stress levels.

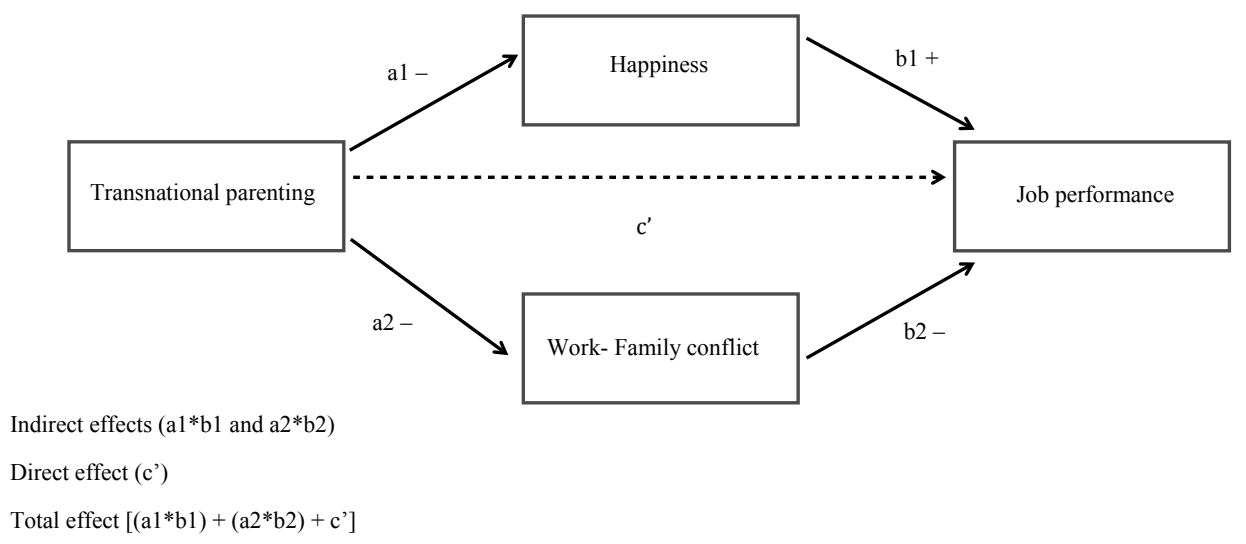

Figure 6.1. Conceptual model of the mediation analysis 


\subsubsection{Analytical strategy}

The hypotheses developed above pertain to the mechanism explaining differences in job outcomes between transnational parents and non-transnational parents. On the one hand, we can expect transnational parents to be less happy which unfavourably affects their job outcomes. On the other hand, we can expect transnational parents to experience less family-to-work conflict leading to favourable job outcomes than nontransnational parents. These hypothesised relationships are depicted in Figure 6.1.

Binary mediation analysis is used to test these hypotheses. This analysis follows the mediation analysis as proposed by Baron and Kenny (1986), but accounts for the binary nature of the mediating variable happiness. The approach used to test mediation is to run four regression models per outcome variable and migrant group. The first condition for mediation is showing that transnational parenting relates to the outcome variable. Second, transnational parenting should relate to the mediating factors happiness and family-to-work conflict, as tested by equations 2 and 3 below. The final step establishes whether transnational parenting is associated with the job outcome variables whilst controlling for the mediating factors (equation 4). Control variables were included in all equations to help avoid statistical confounds.

$$
\begin{aligned}
& \text { Job performance }=\beta 0+(\beta b 1 \text { Happiness }+\beta b 2 \text { Family-work conflict })+\beta c^{\prime} \\
& \text { Transnational parenting }+\beta d \text { covariates }+\varepsilon(\text { equation } 1+4) \\
& \text { Mediator }=\beta 0+\beta a \text { Transnational parenting }+\beta d \text { covariates }+\varepsilon \text { (equation } \\
& 2+3)
\end{aligned}
$$

According to Baron and Kenny (1986) if path ' ' in Figure 6.1, i.e. the coefficient on transnational parenting, is close to zero and non-insignificant when including the mediating factors and the indirect effects are significant, full mediation is found. Using Stata's 'binary_mediation' command, total, indirect and direct effects are calculated, as well as the proportion of the total effect mediated. Bootstrapping with 5000 replications was undertaken to increase statistical power and bias-corrected non-parametric confidence intervals are utilized as the mediated effects are unlikely to be normally distributed (MacKinnon, Lockwood, Hoffman, West, \& Sheets, 2002; Preacher \& Hayes, 2008). Variance inflation factors were below 2.1, indicating that multicollinearity among the independent variables within the models is not a serious concern.

The original sample consisted of 297 Nigerian and 306 Angolan respondents. For this analysis, parents who have children in the country of origin and in The Netherlands are omitted because this would not allow exploring the different mediation paths of interest and test opposite hypotheses. Parents who have children both here and there may experience higher or lower work to family conflict as well as be happier or less happy. Missing data and the above criterion reduced the sample of 265 Nigerian respondents and 255 Angolan respondents, including 100 Nigerian and 86 Angolan 
transnational parents ${ }^{13}$. Finally, because job absenteeism only applies to people in employment, results for models regarding job absenteeism are based on respondents in employment at the time of interview, which resulted in 125 Nigerian and 181 Angolan respondents. As Nigerians and Angolans may have different characteristics, different norms regarding work-family life and assess well-being differently (Diener et al., 2003), we perform separate analyses for both groups.

\subsection{Results}

Table 6.1 reports the descriptive statistics of the included variables. Looking at the mediating factors it is found that the majority of Angolans and Nigerians reported to be happy. Limited family-to-work conflict is reported, especially amongst Nigerians but as indicated before this scale is not reliable for this group. On a scale from 0-5 the average score is $0.17(\mathrm{SD}=0.39)$, while for Angolans it is $0.87(\mathrm{SD}=0.89)$. Angolans report having

Table 6.1. Descriptive statistics

\begin{tabular}{|c|c|c|c|c|c|c|c|c|}
\hline \multirow[b]{2}{*}{ Variables } & \multicolumn{4}{|c|}{ Nigerians } & \multicolumn{4}{|c|}{ Angolans } \\
\hline & Mean & SD & Min & Max & Mean & SD & Min & Max \\
\hline Transnational parenting & 0.36 & 0.48 & 0 & 1 & 0.34 & 0.47 & 0 & 1 \\
\hline Happiness $^{\mathrm{b}}$ & 0.75 & 0.45 & 0 & 1 & 0.77 & 0.42 & 0 & 1 \\
\hline Family-to-work conflict & 0.17 & 0.39 & 0 & 3 & 0.87 & 0.89 & 0 & 3 \\
\hline Age & 38.64 & 6.32 & 26 & 59 & 33.60 & 6.28 & 23 & 59 \\
\hline $\operatorname{Sex}^{c}$ & 0.39 & 0.49 & 0 & 1 & 0.50 & 0.50 & 0 & 1 \\
\hline Marital status $^{\mathrm{d}}$ & 0.15 & 0.35 & 0 & 1 & 0.16 & 0.37 & 0 & 1 \\
\hline Education & 8.85 & 2.36 & 1 & 11 & 7.21 & 2.18 & 0 & 11 \\
\hline Years in Netherlands & 8.69 & 5.94 & 1 & 32 & 14.31 & 4.46 & 0 & 25 \\
\hline Housing ${ }^{\mathrm{e}}$ & 0.78 & 0.42 & 0 & 1 & 0.87 & 0.33 & 0 & 1 \\
\hline Legal status ${ }^{\mathrm{f}}$ & 0.16 & 0.37 & 0 & 1 & 0.01 & 0.09 & 0 & 1 \\
\hline Amount friends NL & 14.53 & 25.70 & 0 & 198 & 31.47 & 39.21 & 0 & 294 \\
\hline Amount family NL & 1.25 & 1.24 & 0 & 26 & 4.52 & 11.08 & 0 & 98 \\
\hline Dutch proficiency & 2.28 & 1.24 & 0 & 4 & 1.36 & 1.05 & 0 & 4 \\
\hline Child $<8$ years $^{\mathrm{g}}$ & 0.49 & 0.50 & 0 & 1 & 0.61 & 0.49 & 0 & 1 \\
\hline Job instability & 1.14 & 1.71 & 0 & 13 & 2.00 & 1.97 & 0 & 9 \\
\hline Job absenteeism & 2.28 & 4.77 & 0 & 30 & 2.41 & 4.01 & 0 & 24 \\
\hline
\end{tabular}

Source: TCRAf-Eu Angolan and Nigerian parent data, The Netherlands, 2010-2011

Notes: Reference categories include a) Non-transnational parent; b) Unhappy; c) Male; d) Married/in a relationship; e) Documented; f) Room, student housing, institution, other; g) No children $<8$ years of age.

\footnotetext{
${ }^{13}$ One respondent in the Nigerian sample and two respondents in the Angolan sample indicated to have changed jobs 20 times while being in The Netherlands, we have omitted these outliers from the analyses.
} 
changed jobs in The Netherlands twice as much as Nigerians, but they have also lived in The Netherlands for a longer period. Both groups missed on average roughly 2 days of work in the three months prior to the interview, but the standard deviation amongst Nigerians is higher (4.8 versus 4 ), indicating that the values are more spread out.

\subsubsection{Mediation analysis}

To test the hypotheses we turn to regression analyses. Following the four steps as proposed by Baron and Kenny (1986), it was first tested whether transnational parenting is associated with job absenteeism and job instability. These results are displayed in Table 6.2. Models 2 and 4 show that transnational parents do not significantly differ from non-transnational parents in terms of the days they were absent from their jobs in the past three months. Also, transnational parenting is not associated with job instability in the Nigerian sample (Model 1). Model 3, however, indicates that, ceteris paribus, Angolan transnational parents change jobs 0.89 times more often $(p<0.01)$ than nontransnational parents. Thus the first condition for mediation is only met for job instability in the Angolan sample. We therefore only continue with the next steps of the mediation analysis only for this group.

Table 6.2. Results mediation analysis Job outcomes

\begin{tabular}{|c|c|c|c|c|c|c|c|c|}
\hline \multirow[b]{4}{*}{ Transnational parenting ${ }^{\mathrm{a}}$} & \multicolumn{4}{|c|}{ Nigerians } & \multicolumn{4}{|c|}{ Angolans } \\
\hline & \multirow{2}{*}{\multicolumn{2}{|c|}{$\begin{array}{c}\text { Model } 1 \\
\text { Job instability }\end{array}$}} & \multirow{2}{*}{\multicolumn{2}{|c|}{$\begin{array}{c}\text { Model } 2 \\
\text { Job absenteeism }\end{array}$}} & \multirow{2}{*}{\multicolumn{2}{|c|}{$\begin{array}{c}\text { Model } 3 \\
\text { Job instability }\end{array}$}} & \multirow{2}{*}{\multicolumn{2}{|c|}{$\begin{array}{c}\text { Model } 4 \\
\text { Job absenteeism }\end{array}$}} \\
\hline & & & & & & & & \\
\hline & 0.56 & $(0.30)$ & 0.32 & $(0.18)$ & 0.89 & $(0.29)^{\star *}$ & -0.10 & $(0.15)$ \\
\hline Age & 0.03 & $(0.02)$ & -0.05 & $(0.02)^{* *}$ & 0.05 & $(0.02)^{*}$ & -0.00 & $(0.01)$ \\
\hline $\operatorname{Sex}^{b}$ & -0.54 & $(0.25)^{*}$ & 0.06 & $(0.16)$ & 0.21 & $(0.26)$ & 0.75 & $(0.14)^{\star * *}$ \\
\hline Marital status ${ }^{\mathrm{c}}$ & 0.41 & $(0.32)$ & 0.06 & $(0.25)$ & 0.43 & $(0.35)$ & 0.03 & $(0.22)$ \\
\hline Education & -0.03 & $(0.05)$ & 0.04 & $(0.04)$ & 0.10 & $(0.06)$ & 0.01 & $(0.03)$ \\
\hline Years in The Netherlands & 0.05 & $(0.02)$ & 0.04 & $(0.01)^{\star *}$ & 0.06 & $(0.03)$ & 0.02 & $(0.02)$ \\
\hline Housing $^{\mathrm{d}}$ & 0.47 & $(0.32)$ & -0.11 & $(0.27)$ & 0.06 & $(0.41)$ & & \\
\hline Legal status ${ }^{\mathrm{e}}$ & -0.65 & $(0.33)$ & -0.37 & $(0.32)$ & & & -0.26 & $(0.21)$ \\
\hline Amount friends NL & 0.04 & $(0.08)$ & -0.11 & $(0.06)$ & 0.08 & $(0.08)$ & -0.06 & $(0.04)$ \\
\hline Amount family NL & 0.31 & $(0.19)$ & -0.02 & $(0.11)$ & -0.06 & $(0.12)$ & 0.03 & $(0.06)$ \\
\hline Dutch proficiency & 0.04 & $(0.09)$ & -0.29 & $(0.06)^{* * *}$ & -0.18 & $(0.12)$ & 0.06 & $(0.07)$ \\
\hline Child $<8$ years of age $\mathrm{f}^{\mathrm{f}}$ & 0.75 & $(0.26)^{* *}$ & 0.13 & $(0.18)$ & 0.33 & $(0.31)$ & 0.48 & $(0.16)^{\star \star *}$ \\
\hline Observations & 249 & & 125 & & 247 & & 181 & \\
\hline
\end{tabular}

Source: TCRAf-Eu Angolan and Nigerian parent data, The Netherlands, 2010-2011.

Notes: Reference categories include a) Non-transnational parent; b) Male; c) Married/in a relationship; d) Room, student housing, institution, other; e) Documented; f) No children $<8$ years of age.

Unstandardized coefficients presented; ${ }^{*} \mathrm{p}<0.05 ;{ }^{* *} \mathrm{p}<0.01 ;{ }^{* *} \mathrm{p}<0.001$ (one-tailed test). 
Figure 6.2 presents the results of the mediation analysis graphically and presents us with the relevant coefficients for each step of the mediation analysis. Table 6.3 displays the indirect, direct and total effects and the proportion of the total effect mediated with bias-corrected confidence intervals after bootstrapping. Although not presented, the model includes the same control variables as in Table 6.2. The second step of mediation requires the independent variable to be related to the mediating variable. Path al represents the association between transnational parenting and happiness and b1 between transnational parenting and family-to-work conflict. As graphically evidenced in Figure 6.2, both paths are significant. First, as posited in hypothesis 2 transnational parents report to be less happy than non-transnational parents. Second, although transnational parenting is significantly associated with family-to-work conflict as postulated in hypothesis 1, it is not in the expected direction. Instead of transnational parents reporting less family-to-work conflict they report more family-to-work conflict. Transnational parents score $0.54(\mathrm{p}<0.001)$ higher on the family-to-work conflict scale (ranges 1-3, mean 0.87 ), which is a significant difference.

Step 2

Step 3

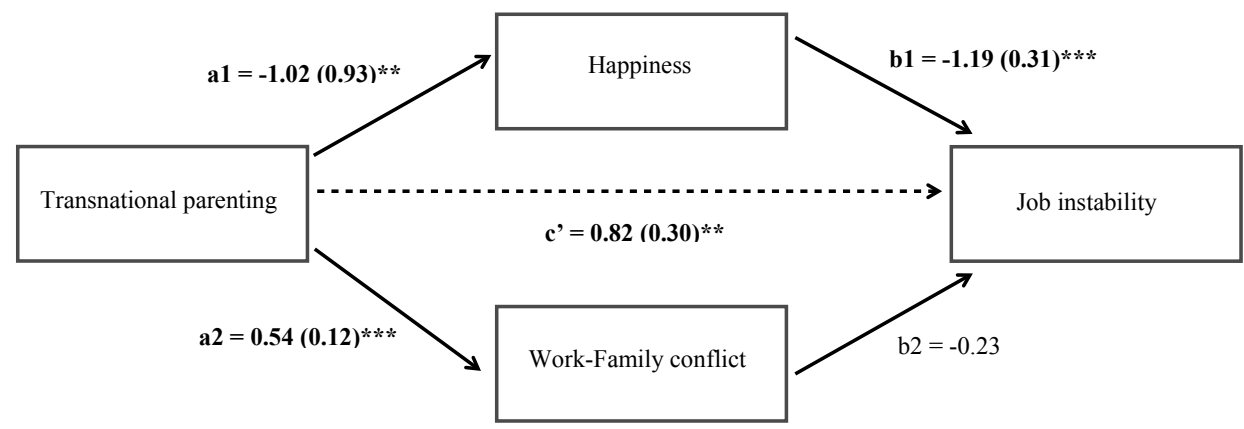

Figure 6.2. Mediation model job instability

Source: TCRAf-Eu Angolan parent data, The Netherlands, 2010-2011.

Notes:

Indirect effects $\left(\mathrm{a} 1^{\star} \mathrm{b} 1\right.$ and $\left.\mathrm{a} 2^{\star} \mathrm{b} 2\right)$

Direct effect (c')

Total effect $\left[\left(\mathrm{a} 1^{\star} \mathrm{b} 1\right)+\left(\mathrm{a} 2^{\star} \mathrm{b} 2\right)+\mathrm{c}^{\prime}\right]$

Percentage total effect mediated $=$ Indirect effects/ Total effect $=15 \%$

Unstandardized OLS coefficients presented, path a1 is an unstandardized logit coefficient ${ }^{\star} \mathrm{p}<0.05 ;{ }^{* \star} \mathrm{p}<0.01 ;{ }^{* *} \mathrm{p}<0.001$ (one-tailed test)

As step two of mediation has been found we continue with the third and final step to investigate whether the relation between transnational parenting and job instability is eliminated or its effect diminished when including the mediating variables, hence happiness and family-to-work conflict. This is captured in path c' of the mediation 
model illustrated in Figure 6.2. If full mediation is found the effect of transnational parenting on job instability should disappear. This is not what is found. Angolan transnational parenting remains significantly related to job instability when including the mediating variables. Additionally, family-to-work conflict is not significantly associated with job instability and hence does not act as a mediator, thereby refuting hypothesis 1 . The second hypothesis is partly confirmed. Lower levels of happiness are significantly related to more job change. Ceteris paribus, respondents reporting to be unhappy change jobs 1.19 times more often than happy respondents $(\mathrm{p}<0.001)$. Plus, as displayed in Table 6.3, the indirect effect of happiness is significant, but not substantial $(B=0.07)$ as only 15 percent of the effect of transnational parenting is mediated through happiness. Thus happiness does not fully explain the association between transnational parenting and job instability. The analysis is taken one step further by looking at possible differences between transnational parents. Especially since, as is explored elsewhere, transnational child raising arrangements of Angolans are functioning more poorly than those of Nigerians (see Haagsman \& Mazzucato, 2014). This may suggest that because Angolan care arrangements more often function poorly in comparison to Nigerians, the job performance of Angolan transnational parents is especially affected and that is why they also experience more family-to-work conflict and job instability.

Table 6.3. Test of mediation with bootstrapped results for job instability of Angolans

\begin{tabular}{lccc}
\hline Mediator & B coefficient & Bias-corrected lower CI & Bias-corrected upper CI \\
\hline Indirect effect (happiness) & 0.07 & 0.01 & 0.15 \\
Indirect effect (conflict) & -0.03 & -0.08 & 0.01 \\
Total indirect effect & 0.04 & -0.03 & 0.12 \\
Direct effect & 0.20 & 0.06 & 0.34 \\
Total effect & 0.23 & 0.09 & 0.38 \\
Proportion of Total Effect Mediated & 0.15 & & \\
\hline
\end{tabular}

Source: TCRAf-Eu Angolan parent data, The Netherlands, 2010-2011.

Notes: The way to interpret the confidence intervals in this table is as follows: if 0 lies within the interval range, no mediation is found.

\subsubsection{Analysis with transnational parents}

The finding that transnational parents experience more not less family-to-work conflict indicates that even though transnational parents do not provide direct care they do feel that their child caregiving responsibilities affects their work. Thus, transnational separation does not necessarily relieve migrant parents of all child caring burdens. As Kossek et al. (2001) indicate, what is more important for experiencing family-work conflict is not the type of care arrangements but the satisfaction with this arrangement. Mazzucato (2011) has argued that a malfunctioning transnational child raising arrangement in which parents feel their child is not being taken care of properly, can prevent the trans- 
national parent from doing the job well because of lack of concentration or because worries can lead to sleepless nights. Yet, when arrangements work well transnational parenting is less problematic. As explored elsewhere, it seems that transnational child raising arrangements that are poor or ill-functioning can affect the relationships parents retain with their children and also impact on happiness (Haagsman \& Mazzucato, 2014; Haagsman et al., 2013). Therefore, one of the reasons why differences between transnational parents and non-transnational parents regarding job instability might be found could be that some of these transnational parents have ill-functioning transnational child raising arrangements causing them to experience stress and consequently to perform less well at their jobs.

Table 6.4. Amount contact child on job instability of transnational Angolan parents

\begin{tabular}{|c|c|c|c|}
\hline & \multicolumn{3}{|c|}{ Job instability } \\
\hline & B & SE & $ß$ \\
\hline Happiness $^{\mathrm{a}}$ & -1.25 & $(0.43)^{* *}$ & -0.32 \\
\hline Family-to-work conflict & 0.40 & $(0.21)$ & 0.22 \\
\hline Age & -0.00 & $(0.05)$ & -0.00 \\
\hline $\operatorname{Sex}^{\mathrm{b}}$ & 0.50 & $(0.46)$ & 0.12 \\
\hline Marital status ${ }^{c}$ & 0.45 & $(0.55)$ & 0.09 \\
\hline Education & 0.30 & $(0.12)^{*}$ & 0.25 \\
\hline Years in The Netherlands & 0.12 & $(0.05)^{*}$ & 0.29 \\
\hline Housing ${ }^{\mathrm{d}}$ & 0.21 & $(0.44)$ & 0.05 \\
\hline Amount friends NL & 0.07 & $(0.11)$ & 0.06 \\
\hline Amount family NL & -0.12 & $(0.19)$ & -0.06 \\
\hline Dutch proficiency & -0.11 & $(0.21)$ & -0.05 \\
\hline Child $<8$ years of age ${ }^{e}$ & -0.22 & $(0.46)$ & -0.06 \\
\hline Amount of contact child & -0.45 & $(0.16)^{* *}$ & -0.31 \\
\hline Observations & 82 & & \\
\hline R-squared & 0.46 & & \\
\hline
\end{tabular}

Source: TCRAf-Eu Angolan parent data, The Netherlands, 2010-2011.

Notes: Reference categories include a) Unhappy; b) Male; c) Married/in a relationship; d) Room, student housing, institution, other; e) No children $<8$ years of age. Unstandardized and standardized coefficients presented; ${ }^{\star} \mathrm{p}<0.05 ;{ }^{\star *} \mathrm{p}<0.01 ;{ }^{\star * \star} \mathrm{p}<0.001$ (one-tailed test).

To investigate the association between poor functioning transnational child raising arrangements and job instability a regression analysis was ran including only transnational parents. The amount of contact the parent has with the child is used as a proxy for poor functioning child raising arrangements as previous analyses indicate this to be the most important factor in explaining poor relationships with children (see Haagsman \& Mazzucato, 2014). In addition, upholding contact is one of the key ways to maintain family ties and to engage in transnational parenting (Carling et al., 2012; Zentgraf \& 
Chinchilla, 2012). The amount of contact is a continuous measure, coded (1) not at all; (2) once or twice a month; (3) once a week; (4) a few times a week and (5) everyday (mean is 3.43). Results of the regression analysis are presented in Table 6.4. This analysis reveals that especially poor functioning transnational child raising arrangements are associated with job instability. That is, Angolan transnational parents who have limited contact with their children have changed their jobs in The Netherlands more often. One unit decrease in contact leads to 0.45 more job changes. Next to happiness $(\beta=0.32)$ the amount of contact with the child is also one of the most important predictors of job change $(\beta=0.31)$ in this regression model.

\subsection{Discussion and conclusions}

This paper aimed to complement research on transnational families by investigating absenteeism and job stability of transnational parents. Whilst the growing body of literature on transnational families has examined how migrant parents raise their children transnationally and how they are affected in their well-being by the separation, it has not explicitly focussed on labour market outcomes. This is an important gap in the literature because the fact that these parents have been found to suffer emotionally from the separation could affect their lives in other areas, such as in their professional lives. Therefore, this study set out to determine whether job outcomes are associated with transnational parenting. By combining insights from organizational psychology with transnational family studies, two opposing hypotheses have been examined. On the one hand, it was hypothesized that transnational parents would experience less family-towork conflict because direct care of their children is provided in the country of origin. On the other hand, based on the happy productive worker thesis, it was hypothesized that as transnational parents are found to display low subjective well-being, job outcomes would be less favourable.

Based on the results of the mediation analyses, the first hypothesis can be refuted. First, Angolan transnational parents experience more family-to-work conflict instead of less. Additionally, family-to-work conflict did not mediate the association between transnational parenting and favourable job outcomes. For Nigerians, it was found that they do not experience a lot of family-work-conflict and it is therefore not a good measure for job performance amongst this group. The second hypothesis is only partly confirmed. First, Angolan transnational parents significantly changed jobs more often than non-transnational parents, but no difference is found with regard to job absenteeism. For Nigerians no significant differences are found in job outcomes between transnational parents and non-transnational parents whilst controlling for socio-economic and demographic factors. Second, Angolan transnational parents' job changes are in part mediated by their lower happiness, but only by 15 percent so the direct effect of transnational parenting remains important. Further analyses indicate that especially 
transnational parents who are in limited contact with their children in Angola experience more job instability. Thus it was argued that transnational parents who engage less in transnational parenting or who are involved in poor functioning transnational chid raising arrangements, are especially affected by the parent-child separation in terms of unfavourable job outcomes.

Several implications can be drawn from these findings relevant for the study of transnational families. First, it is important not to overstate the extent that transnational separation affects parents' job outcomes. Only differences are found with regard to Angolan job instability, not for absenteeism and Nigerian job instability. Also, the finding that especially poor functioning transnational child raising arrangements are associated with job instability implies that when arrangements work well transnational parenting is less problematic.

Nonetheless, the fact that Angolan transnational parents report higher family-towork conflict and more job instability suggests that transnational parent-child separation can affect migrant parents in other areas besides emotional well-being. Although care is arranged transnationally and involves limited physical contact parents continue to be actively engaged in raising their children. Even at a distance migrant parents keep in constant contact with their children and are affected by their children's needs and well-being (Fresnoza-Flot, 2009; Horton, 2009; Parreñas, 2001). The finding that caring for a child can negatively affect transnational parents in their job outcomes, more than non-transnational parents, is perhaps because parents have less control over the care of their child, e.g. in terms of parental authority, and what is happening in the country of origin (Aranda, 2003; Bernhard et al., 2009; Parreñas, 2001). By extension, especially for Angolan transnational parents with limited contact with their children in the origin country, job instability is prevalent. It has been demonstrated empirically that limited contact is associated with poor parent-child relationships, which can cause poor parental emotional well-being (Haagsman \& Mazzucato, 2014; Haagsman et al., 2013). Poorly functioning arrangements can keep transnational parents from performing well at the job because worries can lead to loss of concentration or sleepless nights (Mazzucato, 2011).

The post-conflict context of Angola is another important consideration for why effects are found for this group in particular. Trauma from war can increase effects of family separation because refugees are extra sensitive to additional disruption (Haagsman \& Mazzucato, 2014; Suarez-Orozco et al., 2002). Furthermore, leaving a child in a (post-) conflict and thus unsafe setting can lead to worry and anxiety (Suarez-Orozco et al., 2002). Also, the war has lead to family dislocation, break-up of affective bonds and hence fragmented care networks because almost all families have lost a member through war violence (Nzatuzola, 2006). These fragmented care networks limit the pool of good carers and could lead to worries regarding childcare, which can result in increased work-family conflict and loss of concentration at work. In fact, Angolan children in 
transnational families show lower emotional well-being than children in transnational families in Nigeria and Ghana (Mazzucato et al., 2013). This suggests that transnational family separation may have a larger impact on children living in a post-conflict setting, which in turn can affect transnational parents' well-being. Finally, war and post-conflict settings can keep family members from being in regular contact and lead to long and unplanned separations. This can lead to strained relationships, which are also found to affect parental well-being (Haagsman \& Mazzucato, 2014; Haagsman et al., 2013).

A possible explanation for the insignificant results in the Nigerian sample and the limited amount of family-work work conflict that Nigerians experience could be the fact that a significant part of Nigerians came to The Netherlands for labour purposes. As depicted in the high unemployment rate of the Nigerians in our sample and the discrepancy between levels of education and type of labour these Nigerians are typically in, finding appropriate labour is hard for this group. These socio-contextual circumstances shape how labour is viewed and may affect the extent to which family-to-work conflict is experienced and affect job performance. As explained by Grzywacz et al. (2007), when migrating in search of labour and to provide for the family in a situation where finding labour is hard you make sure that family and work do not come into conflict or at least do not experience this as a problem. You cannot afford to loose your job and income as finding a new position is difficult and you are dependent on the income for family wellbeing. Therefore, you make sure to perform well at the job and do not let family interfere with work.

There are potential limitations of this study that have to be taken into consideration. First, measures of job outcomes in this study are objective measures that can be asked to respondents themselves. Some studies investigating job outcomes or performance use supervisory ratings. Although this latter measure is less objective, it can capture the phenomenon of people feeling stressed and performing less well at the job, while still keeping their job. The measures used in the current study are more conservative as they measure days absent from a job and whether someone keeps a job. Consequently, the effects of transnational parenting on job outcomes may be underestimated, which might explain why no difference is found with regard to job absenteeism. At the same time, the fact that some results are significant is all the more telling given the conservative measures used.

Second, the sampling strategy might have lead to some bias. Random sampling is not possible in this study that requires specific inclusion criteria and as a result the data is not nationally representative. Third, the analysis is based on a relatively small number of observations and hence has limited statistical power, especially with regard to the last analysis including only transnational parents. Fourth, the data are cross-sectional and we can therefore not be conclusive about the causality of the effects. In particular, the association between well-being and job performance may reflect reverse causation and should therefore be interpreted as associations. Longitudinal organizational behavioural 
research has proved job performance and well-being are bidirectional and hints at the reciprocal nature of the relation. Thus, the mediation analysis should be treated as descriptive. Future qualitative and longitudinal studies are required to validate the meditational relations and explore the different mechanisms that are at play.

Despite these limitations, this research is a first attempt to study the association between transnational parenting and job outcomes. It does so by bringing together, previously separate bodies of literature: organizational psychology and transnational family studies. This study indicates that transnational parenting can affect job outcomes of parents and thus have direct consequences for participation in the host society. This is especially true when parents and children are in limited contact leading parents to worry more about their children. Matters that happen thousands of miles away can negatively affect migrants' lives in the receiving country significantly and in various ways. However when arrangements work well transnational parenting is less problematic. 

CHAPTER 7.

Conclusions 



\subsection{Introduction}

Within the past three decades the nature of migration has changed as a result of new technologies of communication and travel, the global division of labour and changing migration policies. As families are increasingly integrated in the global economy, they are affected by events thousands of miles away. However, while families are at the heart of these global processes, studies of migration and globalisation have focussed predominantly on economic aspects (Trask, 2010). Some state that global economic and political inequalities have given rise to transnational family formations (Dreby, 2007; Schmalzbauer, 2004). Although the number of these types of families is unknown, what is certain is that, in light of strict family migration policies and new technologies of communication and travel, the configuration of transnational families is vastly changing. On the one hand, communication technologies and cheaper travel have facilitated better contact across great distances. On the other hand, the greater distances travelled and strict migration policies have created obstacles for reunification and have resulted in protracted separations. As previous studies have indicated, the challenges migrant parents face in this context are many and complex (Dreby, 2006; Fresnoza-Flot, 2009; Hondagneu-Sotelo \& Avila, 1997; Parreñas, 2001, 2005; Schmalzbauer, 2004). In this dissertation I studied one aspect: the association between transnational parent-child separation and the well-being of migrant parents.

As highlighted in Chapter 1, this dissertation contributes to the relatively new but burgeoning field of transnational family studies in several ways. By building on previous small-scale studies on transnational families, this dissertation tries to advance our understanding of the effects of transnational separation by utilising survey data that allowed the analysis of various factors identified by previous studies simultaneously. Transnational families do not exist in a vacuum and therefore should not be studied in isolation. By using survey data and including a group of non-transnational parents, I could study the association between transnational parent-child separation and parental well-being, control for confounding factors, investigate specific moderation and mediation effects, and reveal which conditions are of special importance for the well-being of transnational parents.

Second, this study takes into account different aspects of transnational parents' well-being, i.e., the quality of the transnational parent-child relationship, parents' subjective well-being and health, and the job outcomes of these parents. By studying multiple outcomes and contextualising this with the data this dissertation employs this study could nuance previous findings, showing that different dimensions of well-being are differently associated with transnational family separation. In other words, through the use of various outcome measures, I was able to understand different aspects of migrant parent's lives affected by transnational parent-child separation. 
Third, this dissertation aimed to extend the literature on transnational families by integrating insights from different fields of study, thereby enhancing our understanding of transnational parents' lives. These various disciplines allowed me to look at transnational families in a different way. As various studies in the different disciplines employed indicate, migrants and their families are affected by their socio-economic status, legal status, social networks and the political spheres in which they operate. These studies gave me the tools to contextualise the effects of transnational family life because they provided me with the relevant confounding factors I needed to control for. By taking into account these factors, I found that family separation does not necessarily negatively affect parents' well-being, as some of the differences found between transnational and non-transnational parents were associated with their legal or socio-economic status. Thus, the migrant well-being literature has provided me with insights into transnational family life that I would not have otherwise had. However also, vice versa. By taking transnational family linkages into account in the study of migrant well-being, I have shown that these can be of importance, especially when child raising arrangements do not work well, and need to be taken into account in the migrant well-being literature. In addition, linking organisational psychology and transnational family studies led me to consider the study of job outcomes of transnational parents and suggested that transnational parenting could be associated with job outcomes in various ways.

Finally, this study is comparative in nature. It includes two different sub-Saharan African migrant groups, Angolans and Nigerians. Sub-Saharan African migrant groups are understudied in general but especially with regard to transnational family life. As the countries of origin have a long history of child fostering, the effects of transnational family life might differ from the other contexts that have been studied. Additionally, as will be elaborated upon below, the comparison between Angolans and Nigerians has provided an understanding of the contextual factors that affect transnational family formation and family life, which are generally missing from transnational family studies. In the following I will summarise the findings that resulted from the approach outlined above and the insights that this study provides. I begin by summarising the main empirical findings of this dissertation. This is followed by the theoretical lessons we can draw from these results and some suggestions for further research and policy. More implications for policy are discussed in the valorisation addendum.

\subsection{Main empirical findings}

I began this dissertation by exploring the context in which the Angolan and Nigerian transnational families who are part of this study came into being and currently operate and by investigating the differences between these two groups and between transnational and non-transnational parents. First, Chapter 2 revealed important differences be- 
tween the two groups under study. While Nigerians mainly came to The Netherlands in search of labour and through family reunification/ formation, Angolans entered The Netherlands as asylum seekers. Although both groups were entering the same country, they had to address different migration regimes as a result of the different modes of entry. Consequently, the Angolans generally have a higher socio-economic status than the Nigerians, have significantly more frequent Dutch nationality, and more often speak the Dutch language. The Nigerians, on the other hand, are more often undocumented and have higher educational levels although their qualifications often go unrecognised. These differences and the fact that Angolans have fled a war have resulted in divergent transnational child raising arrangements and have affected the functioning of these arrangements. The Nigerian transnational parents in this study are in a more precarious position in The Netherlands, which affects their right to family reunification, for which legal status and a certain stable income are required.

More importantly, the analyses in Chapters 4, 5 and 6 indicate that in transnational family studies, specific consideration should be given to the intersection of transnational family life, socio-economic and legal status, and demographic characteristics. I found that Nigerian transnational parents are more often undocumented, more often unemployed, and of lower socio-economic status than non-transnational Nigerian parents. Throughout this dissertation, it has become clear that these differences are of vital importance when studying the effects of transnational child-raising arrangements on parents' lives.

We observed in Chapter 3 that the reasons for transnational family separation amongst the respondents are diverse. Reasons can include a lack of proper documentation or economic resources, parents' desire to protect their children from exposure to what is perceived as decadent Dutch culture, and the desire to embed children in the familiar and safe environment of the country of origin. Separation can be a consequence of divorce or separation of the biological parents or parents' desire to live or being forced to live in different localities. Finally, what chapter 3 showed us is that Nigerian transnational parents in comparison to their non-transnational counterparts are especially characterised by low socio-economic status, undocumented status and in terms of their labour market position. Thus, these are important confounding factors that one needs to take into account when studying transnational families. This is exemplified by the analyses in Chapters 5 and 6, where I find that these factors are important in explaining some of the differences in the well-being of transnational and nontransnational parents.

Chapter 4 investigated five factors of importance for the maintenance of transnational parent-child relationships, namely, gender, contact and remittances, the characteristics of the caregiver, the length of separation, and the age of the child and age at separation. Although most of the transnational family literature indicates that relationships deteriorate after transnational parent-child separation, it was found that most 
parents report a good relationship with their children. Yet, Chapter 3 did indicate that the relationship that parents retain with children in The Netherlands is better, for which there can be various reasons. One of the reasons might be the fact that transnational parents are more often divorced, and this is found to be an important indicator of poor parent-child relationships. Caregivers who divorced the migrant parent are less likely to facilitate the relationship between the migrant parent and the child. Hence, the relationship with the caregiver is important for the parent-child relationship, which is also exemplified by the finding that, when the care provided to the child is regarded as poor, the parent-child relationship is also poor. The analyses further indicate that, as the literature suggests, frequent contact is of vital importance for the maintenance of good parent-child relationships. Important differences were found between the Angolans and the Nigerians. The Angolan transnational parents reported significantly poorer relationships with their children, and the length of separation, having young children and the age at separation were significantly associated with the parent-child relationship for the Angolans but not for the Nigerians.

Chapter 5, which was devoted to the subjective well-being of transnational parents, showed that it is important to take structural factors into account when studying the effects of transnational family life. Through multivariate analyses, I nuanced the findings from other qualitative transnational family studies, which commonly point to the strong negative effects of transnational parent-child separation. While initially lower subjective well-being amongst transnational parents was found, in some cases this was diminished or even eliminated when taking socio-economic status, undocumented status and poor parent-child relationships into account. The point here is that we should not study the effects of transnational parenting in isolation because other factors may lie at the heart of lower well-being.

While the effects on emotional well-being have been researched by transnational family scholars, in Chapter 6 a less well-researched dimension of migrant parents' lives was studied, namely, that of job outcomes. In this chapter, I argued that transnational parenting could be associated with job outcomes in two ways. Either it could lead to favourable job outcomes because parents would experience less work-family conflict or it could be associated with unfavourable job outcomes because of parents' lower subjective well-being. First, what the analyses showed is that there are differences in the effects that transnational family separation has on the Angolan and Nigerian migrant parents. Whereas differences between non-transnational and transnational parents were found for the Angolans, no such differences were found for the Nigerians. The Angolan transnational parents experience more family-to-work conflict and more job instability, which is partly mediated by lower levels of happiness. This difference was explained by the finding that the Angolan transnational parents are more often in limited contact with their children, which was found to be associated with more job instability. Hence, I 
concluded that transnational separation does not necessarily impact on job outcomes, except when transnational child raising arrangements are ill-functioning.

The findings of these empirical chapters lead to some important insights. First, contrary to what was expected, no major differences were found between transnational mothers and fathers. They report similar parent-child relationships, generally similar levels of subjective well-being, and comparable job outcomes. More importantly, the interaction effects between transnational parenting and sex on well-being were generally found to be insignificant, indicating that the associations found are similar for transnational mothers and fathers. While the insignificance of sex does not necessarily mean that women do not experience transnational parenting differently than men do due to different normative expectations as argued by qualitative studies, our findings show that overall these differences do not result in significantly different well-being outcomes. This is an important nuance to transnational family studies that point to the particular negative effects that separation has on mothers who cannot live up to the existing norms of co-present mothering and emotional care.

A second finding relates to the importance of the structural factors that contextualise transnational family life. Chapter 3 indicated that transnational parents have especially low socio-economic status, are more often undocumented and are more often unemployed. The implication here is that transnational family life is interrelated with other factors. Both undocumented and low-socio economic status prohibit physical contact and family reunification and can lengthen transnational separations and hence affect the type of migrant likely to be engaged in transnational family life. That is why the analyses in Chapter 5 indicate that transnational family separation is associated with poor parental well-being but not for some measures of well-being when controlling for socio-economic and legal status. For Nigerians, the association between mental health and transnational parenting disappeared when taking into account socio-economic and legal status. For Angolans the association between transnational parenting and life satisfaction ceased to be significant when including confounding factors. Hence, these conditions affect well-being irrespective of transnational family life and explain some of the differences found between transnational and non-transnational parents. Therefore, this study nuances findings from transnational family studies that point to the severe impacts on emotional well-being that are attributed to the separation.

Other structural conditions become apparent when comparing the Angolans and the Nigerians, attesting to the importance of the context of migration. Undocumented status and socio-economic status were particularly relevant for the Nigerians who came as economic migrants but were less important for the Angolans who came as asylum seekers. All empirical chapters suggest that the post-conflict setting in Angola is important to take into account. First, being an asylum seeker without the right to work and the war or post-war setting may restrict parents' ability to keep in regular contact with their children in Angola, which, as Chapter 4 has shown, leads to strained relationships. 
Second, leaving a child in a post-war country can be especially demanding and increase the effects of parent-child separation (Suarez-Orozco et al., 2002), especially when social care networks are fragmented as a result of the war. In addition, as shown in Chapter 5, Angolans already experience lower levels of well-being likely as a result of trauma from war, which can increase the effect that transnational separation has (Suarez-Orozco et al., 2002). Therefore, one important insight of this study is that taking into account the context of migration is imperative to understand transnational family life.

Finally, this dissertation demonstrated the use of including a transnational approach when studying migrant well-being. Family ties in the country of origin affect the well-being of migrant parents in some dimensions, such as happiness for both the Nigerians and the Angolans and mental well-being and job instability for the Angolans. However, what the different chapters also indicate is that when transnational arrangements function well through, for example regular contact and good parent-child and parent-caregiver relationships, transnational separation is less problematic.

\subsection{Contributions to literature}

\subsubsection{The transnational approach and families}

The scholarship of transnationalism has deconstructed the traditional division made between the sending and the receiving society in migration studies since the 1990s. It has taken a perspective on migration that connects the various and multidirectional relationships that cross national borders and that goes beyond a bipolar view of migration (Bryceson \& Vuorela, 2002; Zontini, 2010). However, a large share of the migration literature is focused on either the process of migration, e.g., who migrates; the economic impacts on the country of origin, e.g., the impact of remittances and brain drain; or on aspects related to integration in the host society, e.g., ethnic segregation (Zontini, 2010). Until recently, migration studies have barely taken transnational linkages into account. This dissertation has shown that, to understand migration, including aspects of settlement, we need a transnational perspective on migration that integrates the features of the lives of migrants that go beyond the country of settlement.

An exclusive focus on the context of arrival or on migration from the perspective of one nation-state does not capture the lived experiences of migrants. This does not mean that the context of arrival is unimportant. If anything, this dissertation has shown that it is of crucial importance for the lives of migrants as well as the context of the country of origin. The point I want to make is that we need to reconceptualise our concepts of family and the migrant, and we must incorporate a transnational approach in the study of migrant families, an important sphere in which transnational processes take effect. The empirical chapters of this dissertation indicate that events that happen a thousand 
miles away can impact migrants in the host country, especially when transnational child raising arrangements do not work well.

Although migration scholars increasingly incorporate the family into their research and family sociologists and psychologists recognise the diverse nature of families, such as same-sex marriages, adoption and single parenthood, studies in these disciplines have largely neglected transnational families. These studies emphasise nuclear co-resident families because they consider physical immediacy as a prerequisite for family interaction (Baldassar \& Baldock, 1999; Mazzucato \& Schans, 2011; Schans, 2009; Zontini, 2004). This dissertation represents a case in point that this view of the family is flawed and that physical proximity is not a precondition for being a family. Hence, studies in the areas of family sociology and psychology and migration studies need to broaden their view and include families in which care is arranged transnationally in their research.

\subsubsection{Intersections of socio-economic status, legal status and transnational parenting}

Structural factors, such as the economic conditions and immigration policies of a receiving country, have direct impacts on family life and can strongly influence transnational family dynamics (Fresnoza-Flot, 2009; Trask, 2010; Zontini, 2010). Although the demand for labour in the North does not seem to decrease, migration policies have become stricter. Migration regulations have confined choices of action and spatial mobility, restricting the ability of some family members to live geographically close and creating protracted transnational separations. The documents and stable income that are needed to reunite with their families are often out of reach for these parents, especially when they are undocumented. Some argue that the stringent migration policies in place and the immobility this results in can pose a threat to family life and have a detrimental impact on family relations (Bernhard et al., 2009; Bryceson \& Vuorela, 2002; Cohen, 2000; Kraler et al., 2011; Strik, De Hart, \& Nissen, 2013). The same holds for low socio-economic status. For example, the costs of communication within low-income transnational families can create barriers to communication. Economic insecurity can also strain family ties because the inability to send remittances can damage relationships between the migrant parent and the caregiver and child, who expect economic returns to result from the separation (Carling et al., 2012; Dreby, 2006; Pribilsky, 2004).

In other words, the restrictions and opportunities that result from transnational separation depend on socio-economic status, legal status and the care arrangements in place. Therefore, I have argued during the course of this dissertation that legal, economic, and demographic factors affect migrants and their families. While this may not be a new insight because migration research has consistently shown that these factors are of importance for settlement, how these factors interact with transnational family life is less well-researched. In this dissertation it has been argued that transnational family life does not necessarily pose problems for parents separated from their children. However, 
when arrangements do not work well, for example as a result of divorce or limited contact that leads to poor parent-child relationships, transnational separation can have a significant impact on the migrant parent's life, both in terms of subjective well-being and job outcomes (Mazzucato, 2011).

The restrictions that low socio-economic status and lack of proper documentation impose upon migrant parents can lead to ill-functioning transnational child-raising arrangements. As some studies indicate, when transnational parents do not meet the expectations, such as emotional or financial care, of the children and caregivers in the country of origin, they can be reproached, leading to poor functioning arrangements (Dreby, 2006; Poeze \& Mazzucato, 2013) As theorised in Chapter 4, "remittances are the currency of contact across borders" (Dreby \& Adkins, 2010, p. 680) and one of the ways to conserve transnational relations. Additionally, family visits, which are vital for maintaining good relationships (Carling et al., 2012; Leifsen \& Tymczuk, 2012; Mason, 2004), are difficult for migrants of low socio-economic status, and, without proper documentation, re-entry is hard. Hence, not only do low socio-economic status and undocumented status lead to precarious lives for migrants in general, for transnational parents this situation can also inflict harm to family relations.

\subsubsection{Focus transnational mothers and fathers}

Few scholars have compared the experiences of transnational fathers and mothers. Most scholars have focused on transnational mothers, despite the fact, as this study indicates, that transnational fathers can also be significantly impacted by transnational separation (Poeze \& Mazzucato, 2012). The lack of research on transnational fathers is even more significant when taking into account the fact that the share of transnational fathers is larger than the share of transnational mothers (Pribilsky, 2004; Waters, 2009). It has been argued by several studies on transnational mothers that they face greater challenges because traditional gender norms dictate that they should provide daily care and emotional labour. By contrast, fathers are seen as financial providers, which represents less of a break with traditional gender norms. Additionally, fathers are less involved in transnational care and lack cross-border intimacy (Dreby, 2006; Hondagneu-Sotelo \& Avila, 1997; Parreñas, 2005, 2008). Carling and co-authors (2012), in addition, conclude that, while mothers will be sanctioned when not taking care of their children emotionally or financially, this is often not the case for migrant fathers. As a result, transnational mothers more often feel guilty and distressed than fathers, which can lead to ill health (Horton, 2009; Schmalzbauer, 2004).

While different transnational parenting might be expected from mothers in comparison to fathers, I have found throughout this dissertation that these different forms of transnational parenting do not affect mothers and fathers differently. That is, generally no significant differences are found between mothers and fathers in terms of their wellbeing, and the association between transnational separation and well-being outcomes is 
for the most part similar for mothers and fathers. The same applies to the quality of the transnational parent-child relationship: no differences between mothers and fathers are found. This is in stark contrast to the picture that emerges from most of the ethnographic studies that address transnational parenting. As Waters (2009) states, this negative picture of men might derive from the fact that fathers have rarely been studied. Because transnational family studies, originating in feminist studies, have been focused on the break with traditional gender ideologies, the well-being of fathers has been neglected. This study represents a case in point that future studies should also include fathers because they can be affected as much as mothers can.

\subsection{Future research and policy implications}

In this section I reflect on the key issues for further research and implications for policy. More policy implications are provided in the valorisation addendum at the end of this dissertation.

First, this study revealed that some aspects of transnational child raising arrangements and the way transnational parenting is experienced are particular to migrant origin groups. Hence, the context in which migration takes place and the conditions of settlement are important to take into account. For example, comparative analyses between countries of origin and destination should be included to discern whether certain policies or legal frameworks result in certain family forms. This dissertation has shown the need to include comparison groups and the importance of structural factors to establish the effects of transnational family life. By including a comparison group and confounding factors, this dissertation was able to nuance earlier findings on the effects of transnational family life and attribute them to other structural factors.

Second, surveys used for policy and research on migrant families oftentimes only contain questions on life in the host country and on the people living in the household and hence do not take transnational ties into account. As noted above, this is an important omission because events in the country of origin can affect the well-being of migrants.

Third, despite the fact that the number of migrants from the 'new' immigrant groups is growing, most research in The Netherlands is still focused on the 'traditional' migrant groups (Grillo \& Mazzucato, 2008; Wijk van, 2007). Most research and policy development in The Netherlands concerns the post-colonial migrants from Suriname and the Antilles who came after 1965, and the guest workers from Turkey and Morocco who came in the 1960s and 1970s. What this dissertation has proven is that 'new' migrant groups face different challenges from the 'traditional' migrant groups and therefore are an important group to pursue in national data collection and policy development. For example, the reception by the Dutch government and Dutch society has become more hostile. Consequently, the migration and family reunification policies 
have become much stricter since the 1970s, which has affected the family life of these 'new' immigrant groups. As this dissertation has shown, one of the challenges that these 'new' immigrant groups face is how to live transnational family life. While in the 'old' migrant groups transnational families were also existent, many of the families had the ability to reunite in The Netherlands through family reunification and formation. Yet, the new migration policies in place make this much more difficult for the 'new' immigrant groups. Hence, research and future policies should be based on the needs and issues that the 'new' immigrant groups face and not only on migrant groups who migrated to The Netherlands three generations ago because these groups face/ faced different challenges (Mazzucato, 2008).

Fourth, this dissertation was focused solely on migrant parents in transnational families. However, this is only one side of the caregiving triad. To fully understand transnational family life, children's and caregivers' perceptions should also be included because transnational family life is experienced differently by various members of the family (Bryceson \& Vuorela, 2002; Fresnoza-Flot, 2009; Parreñas, 2005). While there have been studies on children and caregivers in the country of origin, few studies have incorporated the views of these different actors in one and the same family. To be able to study transnational phenomena in depth, one needs a transnational research design, such as a multi-sited research model or a Simultaneous Matched Sample (SMS) method (Mazzucato, 2009a). In the latter method, parents, caregivers and children are studied simultaneously by researchers in two locations who constantly share and crosscheck information. A few studies have already proven the value of such multi-sited studies (e.g. Dreby, 2007; Madianou \& Miller, 2012; Schmalzbauer, 2004), as well as the TCRAf-Eu project this dissertation evolved from. Finally, there is a strong need for longitudinal research to be able to establish causality and to study how transnational child raising arrangements are shaped over time.

Finally, in this dissertation I have argued that when studying migrants it is important to take a transnational approach. This has some implications for policy development. Governments in the North have regarded transnational activities as synonymous with limited loyalty to the new country of residence or as a threat to national unity (Bryceson \& Vuorela, 2002; Waldinger \& Fitzgerald, 2004). It is argued that, if time and interests were invested in the host country, this would greatly help immigrants incorporate into the new society (Guarnizo, Portes, \& Haller, 2003; Levitt, 2003). Yet, transnationalism does not necessarily hinder integration. The two are not mutually exclusive (Guarnizo et al., 2003; Levitt \& Jaworsky, 2007; Mazzucato, 2008; Portes et al., 1999; Snel, Engbersen, \& Leerkes, 2006). This dissertation has shown that these transnational activities are of importance for the lives of migrants in the host country.

For instance, what my research has shown is that, for transnational parents, contact with family in the country of origin is key for maintenance of good transnational parent-child relationships and is also of importance for parents' job outcomes in the host 
country. In addition, good parent-child relationships are found to be consistently associated with improved subjective well-being. In other words, the findings imply that maintaining transnational ties is of crucial importance for the well-being of the parent in the host country. Furthermore, these transnational activities are not only necessary to maintain active family bonds and for improving the well-being of the migrants themselves but are also of vital importance for the emotional and financial well-being of the family members back home. Although not included in this study, research indicates that visits and face-to-face contact are crucial in maintaining affective family bonds. However, strict host country migration policies often prohibit the visits of family members. In conclusion, many migrants will remain engaged both 'here' and 'there', especially where family life is concerned. Therefore, migration and integration policies should not stand in the way of these double engagements, especially because they can better the lives of migrants and their families. 

References 

Abdel-Khalek, A. M. (2006). Measuring happiness with a single item-scale. Social Behavior and Personality: an international journal, 34 (2), 139-150.

Adams, G. A., King, L. A. \& King, D. W. (1996). Relationships of job and family involvement, family social support, and work-family conflict with job and life satisfaction. Journal of Applied Psychology, 81 (4), 411-420.

Åkesson, L., Carling, J. \& Drotbohm, H. (2012). Mobility, Moralities and Motherhood: Navigating the Contingencies of Cape Verdean Lives. Journal of Ethnic and Migration Studies, 38 (2), 237-260.

Al-Ali, N., Black, R. \& Koser, K. (2001). The limits to 'transnationalism': Bosnian and Eritrean refugees in Europe as emerging transnational communities. Ethnic and Racial Studies, 24 (4), 578-600.

Alber, E. (2003). Grandparents as foster parents - Changes in caregiving relationships between grandparents and grandchildren among the Baatombu in northern Benin. Anthropos, 98 (2), 445-460.

Amato, P. R. (2000). The Consequences of Divorce for Adults and Children. Journal of Marriage and Family, $62(4), 1269-1287$.

Amato, P. R. \& Booth, A. (1996). A Prospective Study of Divorce and Parent-Child Relationships. Journal of Marriage and Family, 58 (2), 356-365.

Ammassari, S. (2005). Migration and Development: new strategic outlooks and practical ways forward, the cases of Angola and Zambia. In IOM (Ed.), IOM Migration Research Series (Vol. 21). Genève.

Aranda, E. M. (2003). Global care work and gendered constraints - The case of Puerto Rican transmigrants. Gender \& Society, 17 (4), 609-626.

Bacharach, S. B., Bamberger, P. \& Conley, S. (1991). Work-Home Conflict Among Nurses and Engineers: Mediating the Impact of Role Stress on Burnout and Satisfaction at Work. Journal of Organizational Behavior, 12 (1), 39-53.

Baldassar, L. \& Baldock, C. (1999). Linking migration and family studies: Transnational migrants and the care of ageing parents. In B. Agozino (Ed.), Theoretical and methodological issues in migration research (pp. 57 - 74). Aldershot, UK: Ashgate.

Banfi, L. \& Boccagni, P. (2011). Transnational family life and female migration in Italy: One or multiple patterns? In A. Kraler, E. Kofman, M. Kohli \& C. Schmoll (Eds.), Gender, generations and the family in international migration (pp. 287-311). Amsterdam: Amsterdam University Press.

Baron, R. M. \& Kenny, D. A. (1986). The moderator-mediator variable distinction in social psychological research: Conceptual, strategic, and statistical considerations. Journal of Personality and Social Psycholo$g y, 51(6), 1173-1182$.

Basch, L., Glick Schiller, N. \& Szanton-Blanc, C. (1994). Nations Unbound: Transnational Projects, Postcolonial Predicaments, and Deterritorialized States. London: Gordon \& Breach.

Bernardi, L. (2011). A Mixed-Methods Social Networks Study Design for Research on Transnational Families. Journal of Marriage and Family, 73 (4), 788-803.

Bernhard, J. K., Landolt, P. \& Goldring, L. (2009). Transnationalizing Families: Canadian Immigration Policy and the Spatial Fragmentation of Care-giving among Latin American Newcomers. International Migration, 47 (2), 3-31.

Birman, D. (2006). Ethical Issues in Research with Immigrants and Refugees. In J.E. Trimble \& C.B. Fisher (Eds.), The Handbook of Ethical Research with Ethnocultural Populations and Communities (pp. 155177). Thousand Oaks, CA, US: Sage Publications, Inc.

Boccagni, P. (2012). Practising Motherhood at a Distance: Retention and Loss in Ecuadorian Transnational Families. Journal of Ethnic and Migration Studies, 38 (2), 261-277.

Bonjour, S. (2009). Grens en gezin. Beleidsvorming inzake gezinsmigratie in Nederland, 1955-2005. Universiteit van Maastricht, Maastricht.

Brons, M. \& Schaap, C. (2002). Pilot project: prepared return. Phase I: Profile analysis of Angolans in the Netherlands. The Hague: International Organization for Migration.

Bryceson, D. \& Vuorela, U. (2002). The transnational family. New European frontiers and global networks. Oxford \& New York: Berg. 
Burke, R. J. (1988). Some antecedents and consequences of work-family conflict. Journal of Social Behavior \& Personality, 3 (4), 287-302.

Carling, J. (2006). Migration, Human Smuggling and Trafficking from Nigeria to Europe. International Organization for Migration.

Carling, J., Menjívar, C. \& Schmalzbauer, L. (2012). Central Themes in the Study of Transnational Parenthood. Journal of Ethnic and Migration Studies, 38 (2), 191-217.

Castles, S. (1986). The Guest-Worker in Western Europe - An Obituary. International Migration Review, 20 (4), 761-778.

Castles, S. \& Miller, M. J. (2009). The Age of Migration. Interational Population Movements in the Modern World. (4th ed.). Houndmills, Basington, Hampshire, and London: MacMillan Press (TD).

Central Bureau for Statistics. (2013). Statline. from http://statline.cbs.nl

Coe, C. (2008). The Structuring of Feeling in Ghanaian Transnational Families. City \& Society, 20 (2), 222-250.

Cohen, R. (2000). Mom is a stranger": the negative impact of immigration policies on the family life of Filipina domestic workers. Canadian Ethnic Studies, 32 (3), 76-88.

Cooke, T. J. (2008). Migration in a family way. Population, Space and Place, 14 (4), 255-265.

Cropanzano, R. \& Wright, T. A. (1999). A 5-year study of change in the relationship between well-being and job performance. Consulting Psychology Journal: Practice and Research, 51 (4), 252-265.

Cropanzano, R. \& Wright, T. A. (2001). When a 'happy' worker is really a 'productive' worker: A review and further refinement of the happy-productive worker thesis. Consulting Psychology Journal: Practice and Research, 53 (3), 182-199.

Defence for children \& Vluchtelingenwerk Nederland. (2012). "Hoelang duurt het nog voordat we naar onze moeder kunnen?" Barrières bij de gezinshereniging van vluchtelingen. Leiden and Amsterdam: Defence for children \& Vluchtelingenwerk.

Diener, E., Oishi, S. \& Lucas, R. E. (2003). Personality, Culture, and Subjective Well-Being: Emotional and Cognitive Evaluations of Life. Annual Review of Psychology, 54 (1), 403-425.

Donovan, M. A. (2000). Cognitive, affective, and satisfaction variables as predictors of organizational behaviors: A structural equation modeling examination of alternative models. Dissertation Abstracts International, 60 (9-B). (UMI No. AAI9944835).

Dreby, J. (2006). Honor and virtue - Mexican parenting in the transnational context. Gender \& Society, 20 (1), $32-59$.

Dreby, J. (2007). Children and Power in Mexican Transnational Families. Journal of Marriage and Family, 69 (4), 1050-1064.

Dreby, J. \& Adkins, T. (2010). Inequalities in Transnational Families. Sociology Compass, 4 (8), 673-689.

Dreby, J. \& Stutz, L. (2012). Making something of the sacrifice: gender, migration and Mexican children's educational aspirations. Global Networks, 12 (1), 71-90.

Erel, U. (2002). Reconceptualizing Motherhood: Experiences of Migrant Women from Turkey Living in Germany. In D. Bryceson \& U. Vuorela (Eds.), The transnational family. New European Frontiers and Global Networks. Oxford \& New York: Berg.

Evergeti, V. \& Ryan, L. (2011). Transnational Family Life and Care. In A. Kraler, E. Kofman, M. Kohli \& C. Schmoll (Eds.), Gender, generations and the family in international migration Amsterdam: Amsterdam University Press.

Evergeti, V. \& Zontini, E. (2006). Introduction: Some critical reflections on social capital, migration and transnational families. Ethnic and Racial Studies, 29 (6), 1025-1039.

Falicov, C. J. (2007). Working With Transnational Immigrants: Expanding Meanings of Family, Community, and Culture. Family Process, 46 (2), 157-171.

Fan, F., Su, L., Gill, M. K. \& Birmaher, B. (2012). Emotional and behavioral problems of Chinese left-behind children: a preliminary study. Social Psychiatry \& Psychiatric Epidemiology, 45 (6), 655-664.

Fassaert, T., De Wit, M. A. S., Tuinebreijer, W. C., Knipscheer, J. W., Verhoeff, A. P., Beekman, A. T. F. \& Dekker, J. (2011). Acculturation and Psychological Distress Among Non-Western Muslim Migrants - a Population-Based Survey. International Journal of Social Psychiatry, 57 (2), 132-143. 
Fedyuk, O. (2012). Images of Transnational Motherhood: The Role of Photographs in Measuring Time and Maintaining Connections between Ukraine and Italy. Journal of Ethnic and Migration Studies, 38 (2), 279-300.

Frank, R. \& Wildsmith, E. (2005). The Grass Widows of Mexico: Migration and Union Dissolution in a Binational Context. Social Forces, 83 (3), 919-947.

Fresnoza-Flot, A. (2009). Migration status and transnational mothering: the case of Filipino migrants in France. Global Networks-a Journal of Transnational Affairs, 9 (2), 252-270.

Frone, M. R., Russell, M. \& Cooper, M. L. (1992). Antecedents and outcomes of work-family conflict: Testing a model of the work-family interface. Journal of Applied Psychology, 77 (1), 65-78.

Glick Schiller, N. G., Basch, L. \& Szanton-Blanc, C. (1992). Transnationalism - a New Analytic Framework for Understanding Migration. Annals of the New York Academy of Sciences, 645, 1-24.

Goldberg, D. P. (1992). General Health Questionnaire (GHQ-12).

Goldberg, D. P., Gater, R., Sartorius, N., Ustun, T. B., Piccinelli, M., Gureje, O. \& Rutter, C. (1997). The validity of two version of the GHQ in the WHO study of mental illness in general health care. Psychological Medicine, 27, 191-197.

Goody, E. (1982). Parenthood and social reproduction: fostering and occupational roles in West Africa. Cambridge: Cambridge University Press.

Graham, E. \& Jordan, L. P. (2011). Migrant Parents and the Psychological Well-Being of Left-Behind Children in Southeast Asia. Journal of Marriage and Family, 73 (4), 763-787.

Graham, E. \& Yeoh, B. S. A. (2013). Child Health and Migrant Parents in South-East Asia: Risk and Resilience among Primary School-Aged Children. Asian and Pacific Migration Journal, 22 (3), 297-314.

Greenhaus, J. H. \& Parasuraman, S. (1999). Research on work, family, and gender: Current status and future directions Handbook of gender and work (pp. 391-412). Thousand Oaks, CA, US: Sage Publications, Inc.

Grillo, R. \& Mazzucato, V. (2008). Africa < > Europe: A Double Engagement. Journal of Ethnic and Migration Studies, 34 (2), 175-198.

Grzywacz, J. G., Arcury, T. A., Marín, A., Carrillo, L., Burke, B., Coates, M. L. \& Quandt, S. A. (2007). Workfamily conflict: Experiences and health implications among immigrant Latinos. Journal of Applied Psychology, 92 (4), 1119-1130.

Guarnizo, L. E., Portes, A. \& Haller, W. (2003). Assimilation and transnationalism: Determinants of transnational political action among contemporary migrants. American Journal of Sociology, 108 (6), 1211-1248.

Gureje, O. (1991). Reliability and the factor structure of the Yoruba version of the 12-item General Health Questionnaire. Acta Psychiatrica Scandinavica, 84 (2), 125-129.

Haagsman, K., \& Mazzucato, V. (2014). The Quality of Parent-Child Relationships in Transnational Families: Angolan and Nigerian Migrant Parents in The Netherlands. Journal of Ethnic and Migration Studies, 40 (11), 1677-1696.

Haagsman, K., Mazzucato, V. \& Dito, B. (2013). Effects of Transnational Child Raising Arrangements on the Emotional Wellbeing and Health of Angolan and Nigerian Migrant Parents in The Netherlands. Paper presented at the 4th NORFACE Migration Network Conference "Migration: Global Development, New Frontiers", London.

Haas de, H. (2006). International migration and national development: Viewpoints and policy initiatives in countries of origin; The case of Nigeria. Working papers Migration and Development series: Report 6.

Hardill, I. (2004). Transnational living and moving experiences: intensified mobility and dual-career households. Population, Space and Place, 10 (5), 375-389.

Heelsum, van Anja. (2005). Afrikanen in Nederland. In CBS (Ed.), Bevolkingstrends, 3e kwartaal 2005, 83-89.

Heelsum, van A. \& Hessels, T. (2006). Afrikanen uit Angola, DR Congo, Ethiopië, Nigeria en Sudan in Nederland. Een profiel. The Hague: Institutuut voor Migratie en Etnische Studies \& Ministerie van Justitie.

Heymann, J., Flores-Macias, F., Hayes, J. A., Kennedy, M., Lahaie, C. \& Earle, A. (2009). The impact of migration on the well-being of transnational families: new data from sending communities in Mexico. Community, Work \& Family, 12 (1), 91 - 103. 
Hill, L. (2004). Connections between U.S. Female Migration and Family Formation and Dissolution. Migraciones Internacionales, 2 (3), 60-82.

Hochschild, A. (2000). Global care chains and emotional surplus value. In W. Hutton \& A. Giddens (Eds.), On the Edge: Living with Global Capitalism. London: Jonathan Cape.

Hondagneu-Sotelo, P. \& Avila, E. (1997). "I'm Here, but I'm There": The Meanings of Latina Transnational Motherhood. Gender and Society, 11 (5), 548-571.

Horton, S. (2009). A Mother's Heart is Weighed Down with Stones: A Phenomenological Approach to the Experience of Transnational Motherhood. Culture Medicine and Psychiatry, 33 (1), 21-40.

Hovey, Joseph D. (2000). Psychosocial predictors of acculturative stress in Mexican immigrants. Journal of Psychology, 134 (5), 490-502.

Howell, S. (2009). Adoption of the Unrelated Child: Some Challenges to the Anthropological Study of Kinship. Annual Review of Anthropology, 38, 149-166.

INE (2010). IBEP e Angola: Inquerito integrado sobre o bemestar da populaçao. Instituto Nacional de Estatística e Ministerio do Planeamento, Luanda.

Isiugo-Abanihe, U. C. (1985). Child Fosterage in West Africa. Population and Development Review, 11 (1), 53 73.

Jia, Z., \& Tian, W. (2010). Loneliness of left-behind children: a cross-sectional survey in a sample of rural China. Child: Care, Health and Development, 36 (6), 812-817.

Jolivet, A., Cadot, E., Florence, S., Lesieur, S., Lebas, J. \& Chauvin, Pierre. (2012). Migrant health in French Guiana: Are undocumented immigrants more vulnerable? BMC Public Health, 12 (1), 1-12.

Kennedy, S. \& McDonald, J. T. (2006). Immigrant Mental Health and Unemployment. Economic Record, 82 (259), 445-459.

Kessler, R. C. (1979). Stress, Social Status, and Psychological Distress. Journal of Health and Social Behavior, 20 (3), 259-272.

Kofman, E. (2004). Family-related migration: A critial review of European studies. Journal of Ethnic and Migration Studies, 30 (2), 243-262.

Koser, K. (2003). New African Diasporas. London: Routledge.

Kossek, E. E. (1990). Diversity in child care assistence needs: Employee problems, prefrences and, workrelated outcomes. Personnel Psychology, 43 (4), 769-791.

Kossek, E. E., Jason, A. C. \& Noe, R. A. (2001). Caregiving Decisions, Well-Being, and Performance: The Effects of Place and Provider as a Function of Dependent Type and Work-Family Climates. The Academy of Management Journal, 44 (1), 29-44.

Kraler, A., Kofman, E., Kohli, M. \& Schmoll, C. (2011). Gender, Generations and the Family in International Migration. Amsterdam: Amsterdam University Press.

Lapierre, L. M. \& Allen, T. D. (2006). Work-supportive family, family-supportive supervision, use of organizational benefits, and problem-focused coping: Implications for work-family conflict and employee well-being. Journal of Occupational Health Psychology, 11 (2), 169-181.

Larsen, R. J., Diener, E. \& Emmons, R. A. (1985). An evaluation of subjective well-being measures. Social Indicators Research, 17 (1), 1-17.

Leerkes, A. \& Kulu-Glasgow, I. (2011). Playing hard(er) to get. The State, International Couples, and the Income Requirement. European Journal of Migration and Law, 13, 95-121.

Leifsen, E. \& Tymczuk, A. (2012). Care at a Distance: Ukrainian and Ecuadorian Transnational Parenthood from Spain. Journal of Ethnic and Migration Studies, 38 (2), 219-236.

Levitt, P. (2003). Keeping feet in both worlds: transnational practices and immigrant incorporation in the United States. In C. Joppke \& E. Morawska (Eds.), Towards assimilation and citizenship: immigrants in liberal nation-states (pp. 177-194). Basingstoke, New York: Palgrave Macmillan.

Levitt, P. \& Jaworsky, N. (2007). Transnational migration studies: Past developments and future trends. Annual Review of Sociology, 33 (1), 129-156.

Levitt, P. \& Waters, M. C. (2002). Introduction. In P. Levitt \& M. C. Waters (Eds.), The Changing Face of Home: The Transnational Lives of the Second Generation. New York: Russel Sage Foundation. 
Lyubomirsky, S., King, L. \& Diener, E. (2005). The Benefits of Frequent Positive Affect: Does Happiness Lead to Success? Psychological Bulletin, 131 (6), 803-855.

MacKinnon, D. P., Lockwood, C. M., Hoffman, J. M., West, S. G. \& Sheets, V. (2002). A comparison of methods to test mediation and other intervening variable effects. Psychol Methods, 7 (1), 83-104.

Madianou, M. \& Miller, D. (2011). Mobile phone parenting: Reconfiguring relationships between Filipina migrant mothers and their left-behind children. New Media \& Society, 13 (3), 457-470.

Madianou, M. \& Miller, D. (2012). Migration and New Media: Transnational Families and Polymedia. Abingdon and New York: Routledge.

Mason, J. (2004). Managing Kinship over Long Distances: The Significance of 'The Visit'. Social Policy and Society, 3 (04), 421-429.

Mazzucato, V. (2008). The Double Engagement: Transnationalism and Integration. Ghanaian Migrants, Äô Lives Between Ghana and The Netherlands. Journal of Ethnic and Migration Studies, 34 (2), 199-216.

Mazzucato, V. (2009a). Bridging boundaries with a transnational research approach: a simultaneous matched sample methodology. In M. Falzon (Ed.), Multi-sited ethnography (pp. 215-232). Farnham: Ashgate.

Mazzucato, V. (2009b). Effects of transnational child-raising arrangements on life-chances of children, migrant parents and caregivers between Africa and Europe (TCRAf-Eu): NORFACE Grant number 315. Retrievable from http://www.tcra.nl.

Mazzucato, V. (2011). Reverse remittances in the migration-development nexus: two-way flows between Ghana and the Netherlands. Population, Space and Place, 17 (5), 454-468.

Mazzucato, V. (2013a). Child Well-Being and Transnational Families. In A. C. Michalos (Ed.), Encyclopedia of Quality of Life Research. Dordrecht: Springer Netherlands.

Mazzucato, V. (2013b). Transnational families, research and scholarship The Encyclopedia of Global Human Migration: Blackwell Publishing Ltd.

Mazzucato, V., Cebotari, V, Veale, A., White, A., Grassi, M. \& Vivet, J. (2013). Transnational migration and the emotional well-being of children in Ghana, Angola, and Nigeria. Paper presented at the Conference on Transnational Families: Multi-sited, mixed method and comparative research approaches, Maastricht.

Mazzucato, V. \& Schans, D. (2011). Transnational Families and the Well-Being of Children: Conceptual and Methodological Challenges. Journal of Marriage and Family, 73 (4), 704-712.

Mazzucato, V. van Dijk, R., Horst, C. \& de Vries, P. (2004). Transcending the nation: Explorations of transnationalism as a concept and phenomenon. In D. Kalb, W. Pansters \& H. Siebers (Eds.), Globalization \& Development. Themes and Concepts in Current Research (pp. 131-162). Dordrecht: Kluwer Academic Publishers.

McDaniel, A. \& Zulu, E. (1996). Mothers, fathers, and children: Regional patterns in child-parent residence in sub-Saharan Africa. African Population Studies, 11 (1), 1-28.

McLanahan, S. \& Adams, J. (1987). Parenthood and Psychological Well-being. Annual Review of Sociology, 13, 237-257.

Menjívar, C. (2012). Transnational Parenting and Immigration Law: Central Americans in the United States. Journal of Ethnic and Migration Studies, 38 (2), 301-322.

Monaghan, J. \& Just, P. (2000). Social \& Cultural Anthropology: A very short introduction. New York: Oxford University Press.

Muus, P. (2001). International Migration and the European Union, Trends and Consequences. European Journal on Criminal Policy and Research, 9 (1), 31-49.

Nakano Glenn, E. (1983). Split household, small producer and dual wage earner: An analysis of ChineseAmerican family strategies. Journal of Marriage and the Family, 45 (February), 35-46.

NDHS (2008). Nigeria Demographic and Health Survey 2008.

Nobles, J. (2011). Parenting From Abroad: Migration, Nonresident Father Involvement, and Children's Education in Mexico. Journal of Marriage and Family, 73 (4), 729-746.

Nzatuzola, J. B. L. (2006). Gender and Family life in Angola: Some aspects of the post-war conflict concerning displaced persons. African sociological review, 9 (2), 106-133. 
Obdeijn, H. \& Schover, M. (2008). Komen en gaan. Immigratie en emigratie in Nederland vanaf 1550. Amsterdam: Bert Bakker.

OECD. (2008). A profile of immigrant populations in the 21st Century: Data from OECD countries.

Øien, C. (2006). Transnational networks of care: Angolan children in fosterage in Portugal. Ethnic and Racial Studies, 29 (6), 1104-1117.

Olde Monnikhof, M. \& Tillaart van den, H. (2003). Alleenstaande minderjarige asielzoekers in Nederland. ITS, Stichting Katholieke Universiteit te Nijmegen.

Parreñas, R. S. (2000). Migrant Filipina domestic workers and the international division of reproductive labor. Gender \& Society, 14 (4), 560-580.

Parreñas, R. S. (2001). Mothering from a distance: Emotions, gender, and intergenerational relations in Filipino transnational families. Feminist Studies, 27 (2), 361-390.

Parreñas, R. S. (2005). Long distance intimacy: class, gender and intergenerational relations between mothers and children in Filipino transnational families. Global Networks-a Journal of Transnational Affairs, 5 (4), 317-336.

Parreñas, R. S. (2008). Transnational fathering: Gendered conflicts, distant disciplining and emotional gaps. Journal of Ethnic and Migration Studies, 34 (7), 1057-1072.

Pavot, W. \& Diener, E. (2008). The Satisfaction With Life Scale and the emerging construct of life satisfaction. The Journal of Positive Psychology, 3 (2), 137-152.

Pearlin, L. I., Menaghan, E. G., Lieberman, M. A. \& Mullan, J. T. (1981). The Stress Process. Journal of Health and Social Behavior, 22 (4), 337-356.

Pelled, L. H. \& Xin, K. R. (1999). Down and Out: An Investigation of the Relationship between Mood and Employee Withdrawal Behavior. Journal of Management, 25 (6), 875-895.

Poeze, M. \& Mazzucato, V. (2012). Transnational fathering between Ghana and the Netherlands: Fathers' perceptions, obstacles and opportunities. Paper presented at the Conference 'Rethinking care: Anthropological perspectives on life courses, kin-work and their trans-local entanglements', 6-7 December 2012, Humboldt Universitat Berlin.

Poeze, M. \& Mazzucato, V. (2013). African transnational families: Child fostering of Ghanaian youths when mothers and fathers migrate to the global North. In L. Baldassar \& L. Merla (Eds.), Transnational families, migration and kin-work: From care chains to care circulation. (pp. 149-169): Routledge Transnationalism Series.

Portes, A., Guarnizo, L. E. \& Landolt, P. (1999). The study of transnationalism: pitfalls and promise of an emergent research field. Ethnic and Racial Studies, 22 (2), 217-237.

Portes, A., \& Rumbaut, R. (2001). Legacies: The Story of the Immigrant Second Generation. Berkeley: University of Caliornia Press.

Preacher, K. J. \& Hayes, A. F. (2008). Asymptotic and resampling strategies for assessing and comparing indirect effects in multiple mediator models. Behavior Research Methods, 40 (3), 879-891.

Pribilsky, J. (2004). 'Aprendemos a convivir': conjugal relations, co-parenting, and family life among Ecuadorian transnational migrants in New York City and the Ecuadorian Andes. Global Networks-a Journal of Transnational Affairs, 4 (3), 313-334.

Prilleltensky, I. (2008). Migrant Well-Being is a Multilevel, Dynamic, Value Dependent Phenomenon. American Journal of Community Psychology, 42 (3-4), 359-364.

Rask, E., Warsame, M. \& Borell, K. (2014). Gendered family roles and expectations in transnational somali refugee families: an exploratory multiple-site study. International Journal of Child, Youth and Family Studies, 5 (2), 296-307.

Rechel, B., Mladovsky, P., Ingleby, D., Mackenbach, J. P. \& McKee, M. (2013). Migration and health in an increasingly diverse Europe. The Lancet, 381 (9873), 1235-1245.

Reynolds, T. \& Zontini, E. (2006). A Comparative Study of Care and Provision Across Caribbean and Italian Transnational Families. Families \& Social Capital ESRC Research Group Working Paper. London South Bank University.

Rosenfeld, R. A. (1992). Job Mobility and Career Processes. Annual Review of Sociology, 18, 39-61. 
Safi, M. (2010). Immigrants' Life Satisfaction in Europe: Between Assimilation and Discrimination. European Sociological Review, 26 (2), 159-176.

Salaff, J. W. \& Greve, A. (2004). Can women's social networks migrate? Women's studies international forum, 27 (2), 149-162.

Salah, M. A. (2008). The Impacts of Migration on Children in Moldova. In UNICEF (Ed.). New York: UNICEF. Save the Children. (2006). Left behind, left out. The impact on Children and Families of Mothers Migrating for Work Abroad. Colombo: Save the Children in Sri Lanka.

Schans, D. (2009). Transnational family ties of immigrants in the Netherlands. Ethnic and Racial Studies, 32 (7), 1164-1182.

Schmalzbauer, L. (2004). Searching for Wages and Mothering from Afar: The Case of Honduran Transnational Families. Journal of Marriage and Family, 66 (5), 1317-1331.

Schmalzbauer, L. (2008). Family divided: the class formation of Honduran transnational families. Global Networks, 8 (3), 329-346.

Sicherman, N. \& Galor, O. (1990). A Theory of Career Mobility. Journal of Political Economy, 98 (1), 169-192.

Simon, D. (2001). The bitter harvest of war: continuing social \& humanitarian dislocation in Angola. Review of African Political Economy, 28 (90), 503-520.

Smith, R. C. (2006). Mexican New York: Transnational lives of new immigrants. Berkely, CA: University of California Press.

Snel, E., Engbersen, G. \& Leerkes, A. (2006). Transnational involvement and social integration. Global Networks-a Journal of Transnational Affairs, 6 (3), 285-308.

Spitzer, D., Neufeld, A., Harrison, M., Hughes, K. \& Stewart, M. (2003). Caregiving in transnational context "My wings have been cut; where can I fly?". Gender \& Society, 17 (2), 267-286.

Stack, S. \& Eshleman, J. R. (1998). Marital Status and Happiness: A 17-Nation Study. Journal of Marriage and Family, 60 (2), 527-536.

Staw, B. M., Sutton, R. I. \& Pelled, L. H. (1994). Employee Positive Emotion and Favorable Outcomes at the Workplace. Organization Science, 5 (1), 51-71.

Strik, T., De Hart, B. \& Nissen, E. (2013). Family reunification: a barrier or facilitator of integration? A comparative study. HW Oisterwijk: Wolf Legal Publishers.

Suarez-Orozco, C., Todorova, I. L. G., \& Louie, J. (2002). Making up for lost time: The experience of separation and reunification among immigrant families. Family Process, 41 (4), 625-643.

Sudano, J. J., \& Baker, D. W. (2006). Explaining US racial/ethnic disparities in health declines and mortality in late middle age: The roles of socioeconomic status, health behaviors, and health insurance. Social Science \& Medicine, 62 (4), 909-922.

Thomas, L. T. \& Ganster, D. C. (1995). Impact of family-supportive work variables on work-family conflict and strain: A control perspective. Journal of Applied Psychology, 80 (1), 6-15.

Thomas, W.I. \& Znaniecki, F. (1927). The Polish peasant in Europe and America. New York: Knopf.

Thompson, C. A., Beauvais, L. L., \& Lyness, K. S. (1999). When Work-Family Benefits Are Not Enough: The Influence of Work-Family Culture on Benefit Utilization, Organizational Attachment, and WorkFamily Conflict. Journal of Vocational Behavior, 54 (3), 392-415.

Tizard, B. (1991). Employed Mothers and the Care of Young Children. In A. Phoenix, A. Woollet \& E. Lloyd (Eds.), Motherhood: Meaning, Practices and Ideologies (pp. 178-194). London: Sage.

Trask, B. S. (2010). Globalization and Families. Accelerated Systemic Social Change.: Springer New York.

Umberson, D. (1989). Relationships with Children: Explaining Parents' Psychological Well-Being. Journal of Marriage and Family, 51 (4), 999-1012.

UNHCR. (2002). UNHCR Statistical Yearbook.

Vega, W. A. \& Rumbaut, R. G. (1991). Ethnic-Minorities and Mental-Health. Annual Review of Sociology, 17, 351-383.

Voydanoff, P. (2002). Linkages Between the Work-family Interface and Work, Family, and Individual Outcomes: An Integrative Model. Journal of Family Issues, 23 (1), 138-164. 
Waldinger, R. \& Fitzgerald, D. (2004). Transnationalism in question. American Journal of Sociology, 109 (5), 1177-1195.

Walsum van, S. (2003). Comment on the Sen Case. How Wide is the Margin of Appreciation Regarding the Admission of Children for Purposes of Family Reunification? European Journal of Migration and Law, 4, 511-520.

Warmerdam, J. \& van den Tillaart, H. (2002). Arbeidspotentieel en arbeidsmarktloopbanen van vluchtelingen en asielgerechtigden; een verkennend onderzoek naar ervaringen van nieuwkomers op de Nederlandse arbeidsmarkt. Nijmegen: ITS.

Waters, J. L. (2009). Becoming a father, missing a wife: Chinese transnational families and the male experience of lone parenting in Canada. Population, Space and Place, 16 (1), 63-74.

Waters, J. L. (2011). Time and Transnationalism: A Longitudinal Study of Immigration, Endurance and Settlement in Canada. Journal of Ethnic and Migration Studies, 37 (7), 1119-1135.

Watson, J. (1977). Between two cultures: Migrants and Minorities in Britain. Oxford: Basil Blackwell.

Wen, M. \& Lin, D. (2012). Child Development in Rural China: Children Left Behind by Their Migrant Parents and Children of Nonmigrant Families. Child Development, 83 (1), 120-136.

Whitehouse, B. (2009). Transnational childrearing and the preservation of transnational identity in Brazzaville, Congo. Global Networks-a Journal of Transnational Affairs, 9 (1), 82-99.

Wijk van, J. (2007). Luanda-Holanda : irreguliere (asiel)migratie van Angola naar Nederland. Nijmegen: Wolf Legal Publishers.

Wijk van, J. (2008). Luanda-Holanda: Irregular Migration from Angola to the Netherlands. International Migration, 48 (2), 1-30.

Wiley, D. L. (1987). The Relationship Between Work/Nonwork Role Conflict and Job-Related Outcomes: Some Unanticipated Findings. Journal of Management, 13 (3), 467.

WODC. (2009). Migratie naar en vanuit Nederland. Een eerste proeve van de Migratiekaart. The Hague: Minsterie van Justitie.

Wong, M. (2006). The Gendered Politics of Remittances in Ghanaian Transnational Families. Economic Geography, 82 (4), 355-381.

Wright, K. (2011). Constructing Migrant Wellbeing: An Exploration of Life Satisfaction Amongst Peruvian Migrants in London. Journal of Ethnic and Migration Studies, 37 (9), 1459-1475.

Wright, T. A. \& Cropanzano, R. (1998). Emotional exhaustion as a predictor of job performance and voluntary turnover. Journal of Applied Psychology, 83 (3), 486-493.

Wright, T. A., Cropanzano, R. \& Bonett, D. G. (2007). The moderating role of employee positive well being on the relation between job satisfaction and job performance. Journal of Occupational Health Psychology, $12(2), 93-104$.

Wright, T. A., Cropanzano, R., Denney, P. J. \& Moline, G. L. (2002). When a happy worker is a productive worker: A preliminary examination of three models. Canadian Journal of Behavioural Science/Revue canadienne des sciences du comportement, 34 (3), 146-150.

Wright, T. A. \& Staw, B. M. (1999). Affect and favorable work outcomes: two longitudinal tests of the happyproductive worker thesis. Journal of Organizational Behavior, 20 (1), 1-23.

Zentgraf, K. M. \& Chinchilla, N. S. (2012). Transnational Family Separation: A Framework for Analysis. Journal of Ethnic and Migration Studies, 38 (2), 345-366.

Zill, N., Morrison, D. R. \& Coiro, M. J. (1993). Long-term effects of parental divorce on parent-child relationships, adjustment, and achievement in young adulthood. Journal of Family Psychology, 7 (1), 91-103.

Zimmerman, F. J. (2003). Cinderella Goes to School. Journal of Human Resources, 38 (3), 557-590.

Zlotnik, H. (1995). Migration and the family: the female perspective. Asian and Pacific Migration Journal, 4 (2-3), 253-271.

Zontini, E. (2004). Immigrant women in Barcelona: Coping with the consequences of transnational lives. Journal of Ethnic and Migration Studies, 30 (6), 1113-1144.

Zontini, E. (2010). Transnational Families, Migration, and Gender: Moroccan and Filipino Women in Bologna and Barcelona. New York and Oxford: Berghahn Books. 
Nederlandse samenvatting (summary in Dutch) 

Zogeheten transnationale gezinnen, gezinnen waarvan de leden in verschillende landen woonachtig zijn, zijn het onderwerp van deze studie. Deze dissertatie richt zich specifiek op gezinnen waarin één of beide ouders, in deze studie van Angolese en Nigeriaanse afkomst, naar Nederland migreren maar waarvan het kind (nog) in het land van herkomst woont. De zorg voor het kind wordt toevertrouwd aan een verzorger die bijvoorbeeld de andere ouder kan zijn, een grootouder, tante, oom, of in enkele gevallen iemand buiten de grootfamilie. Er zijn verscheidene redenen voor deze scheiding van ouder en kind. Sommige ouders migreren om in het onderhoud van hun kinderen te voorzien en nemen hun kinderen bewust niet mee omdat migratie hoge kosten met zich meebrengt voor kinderen, zowel economisch als sociaal. Denk bijvoorbeeld aan ouders die het onderwijs van kinderen niet willen verstoren of ouders die willen dat kinderen opgroeien in de aanwezigheid van de grootfamilie. Andere scheidingen zijn ongewild en kunnen bijvoorbeeld voortkomen uit rigide migratiebeleid. Deze dissertatie richt zich op de migrantenouders in deze gezinnen en op de effecten die deze scheiding op hun leven heeft.

Alhoewel transnationale gezinnen al eeuwen bestaan, zijn toenemende mondialisering en wereldwijde economische integratie van grote invloed geweest op het ontstaan en opereren van deze familievorm. Sommige wetenschappers stellen dat de komst van de informatiesamenleving met moderne technologieën, toenemende internationale arbeidsdeling en internationale migratie het aantal transnationale gezinnen heeft doen groeien. Hoewel er alleen maar schattingen zijn en het exacte aantal transnationale gezinnen onbekend is, is wel zeker dat deze gezinnen in totaal andere omstandigheden opereren dan enkele decennia geleden. Enerzijds hebben nieuwe informatie en communicatie technologieën en snellere en goedkopere manieren van vervoer de mogelijkheden tot internationaal contact verbeterd. Anderzijds hebben de grotere afstanden die worden afgelegd en streng migratiebeleid geresulteerd in langdurige gezinsscheidingen.

Deze transnationale scheiding kan effecten hebben op het functioneren van de ouder in het vestigingsland. Onderzoek toont bijvoorbeeld aan dat de relatie tussen ouder en kind kan verslechteren ten gevolge van verminderd fysiek contact. Dit kan resulteren in een verhoogd stressniveau bij ouders en in sommige gevallen zelfs tot depressie. Eenzaamheid, schuldgevoelens en het gevoel de ouderlijke autoriteit te verliezen dragen hieraan bij. Vooral crisissituaties, bijvoorbeeld wanneer het kind ziek is, kunnen leiden tot gevoelens van machteloosheid en in verminderd emotioneel welzijn resulteren. Dit zou tot gevolg kunnen hebben dat ouders gericht blijven op het thuisland en minder goed presteren in hun werk en in de samenleving van het vestigingsland. Deze dissertatie heeft tot doel de kennis over de effecten van transnationale scheiding te bevorderen en te onderzoeken of transnationale scheiding tussen ouder en kind van invloed is op het leven van de migrantenouder. 
Voor deze dissertatie maak ik gebruik van survey data waarin ook niet transnationale ouders zijn opgenomen. Met deze data is het mogelijk de relatie tussen transnationale gezinsscheiding en ouderlijk welzijn te testen en te bestuderen, te controleren voor verstorende factoren, mediatie en moderatie effecten te bestuderen, en te onderzoeken welke condities van speciaal belang zijn voor het welzijn van transnationale ouders. Daarnaast worden in deze dissertatie verschillende aspecten van ouderlijk welzijn belicht, namelijk de kwaliteit van de relatie tussen transnationale ouder en kind, ervaren of subjectief welzijn en gezondheid en arbeidsparticipatie. Deze associaties worden bestudeerd onder Angolese en Nigeriaanse ouders in Nederland. Dit vergelijkend perspectief biedt inzicht in de contextuele factoren die een rol spelen in de formatie van transnationale gezinnen en de gevolgen op ouderlijk welzijn. Ik richt me nu de belangrijkste bevindingen van dit onderzoek.

\section{Resultaten}

Deze dissertatie begon met een beschrijvend hoofdstuk waarin de twee groepen deel van deze studie besproken werden. Dit hoofdstuk wees uit dat er belangrijke verschillen bestaan in de migratie van Angolezen en Nigerianen naar Nederland. Nigerianen zijn voornamelijk als arbeidsmigranten of gezinsmigranten naar Nederland gekomen. Angolezen, in tegenstelling, zijn hoofdzakelijk als asielzoekers Nederland binnengekomen. Als gevolg hebben Angolezen over het algemeen een hogere sociaaleconomische status, vaker de Nederlandse nationaliteit, en zijn vaker de Nederlandse taal vaardig. Nigerianen zijn daarentegen hoger opgeleid, al worden hun kwalificaties vaak niet erkend, en zijn vaker ongedocumenteerd. Deze karakteristieken, zo blijkt in deze dissertatie, zijn cruciaal voor het opereren van transnationale gezinnen. Eén van de belangrijkste bevindingen is namelijk dat de intersectie van transnationaal gezinsleven, sociaaleconomische status en de rechtspositie van een migrant belangrijke verklarende factoren zijn voor het verminderd welzijn van ouders. De onderzoeksgegevens tonen bijvoorbeeld dat Nigeriaanse transnationale ouders vaker ongedocumenteerd, werkloos, en van lagere sociaaleconomische status zijn dan niet-transnationale Nigeriaanse ouders.

Het eerste empirische hoofdstuk, hoofdstuk 4, onderzocht de kwaliteit van de transnationale ouder-kind relatie. Alhoewel de literatuur aangeeft dat de relatie tussen ouder en kind op den duur verslechterd, rapporteerden de meeste transnationale ouders een goede relatie met hun kind. Toch zijn de relaties tussen ouder en kind minder goed in transnationale gezinnen dan in niet-transnationale gezinnen. We vonden dat verschillende factoren van invloed waren op deze relatie in transnationale gezinnen. Ten eerste rapporteren migrantenouders wiens kinderen verblijven bij hun ex-partner vaker een slechtere relatie met hun kind. Deze ex-partners hebben waarschijnlijk vaker een moeizame relatie met de verzorger en daarom zijn verzorgers minder bereid om de relatie tussen migrantenouder en kind te faciliteren dan verzorgers met wie de relatie 
met de migrantenouder beter is. Dit blijkt ook uit de bevinding dat als de migrantenouder de zorg door de verzorger slecht vind de ouder-kind relatie ook vaak slecht is. De belangrijkste verklarende factor voor verminderde kwaliteit van de relatie tussen ouder en kind is de mate van contact tussen ouder en kind. Regelmatig contact heeft een significant betere ouder-kind relatie tot gevolg. Ten slotte zijn er belangrijke verschillen tussen Angolezen en Nigerianen. Angolese transnationale ouders hebben een significant slechtere relatie met hun kinderen dan Nigerianen. Ook de tijdsduur van de scheiding, het hebben van jonge kinderen en de leeftijd bij scheiding zijn alleen verbonden aan de ouder-kind relatie bij Angolezen.

Hoofdstuk vijf onderzocht de ervaren of het subjectieve welzijn van transnationale ouders en toonde aan dat structurele factoren belangrijke verklaringsfactoren zijn voor het verminderd ervaren welzijn van transnationale ouders. Hoewel transnationale ouders op het eerste gezicht een lager welzijnsniveau toonden op het vlak van fysieke gezondheid, mentaal welzijn, geluk en levenstevredenheid, verminderde en in sommige gevallen verdween het verschil tussen transnationale en niet-transnationale ouders op het moment dat sociaaleconomische status, rechtspositie van de migrant en de ouderkind relatie werden opgenomen in de analyse. Deze bevinding nuanceert de resultaten van andere (etnografische) transnationale gezinsstudies die veelal op de negatieve effecten van transnationale scheiding wijzen. Deze studie toont aan dat deze scheiding inderdaad tot een lager welzijn kan leiden, maar dat we de effecten van transnationaal ouderschap niet in afzondering moeten bestuderen. Immers contextuele factoren kunnen het lager welzijn in sommige gevallen verklaren. Bijvoorbeeld het feit dat Nigeriaanse transnationale ouders vaker ongedocumenteerd zijn en een lage sociaaleconomische status hebben verklaard hun verminderd mentaal welzijn, niet de transnationale scheiding op zichzelf.

Gevolgen van transnationale scheiding op arbeidsdeelname stonden centraal in hoofdstuk 6. In dit hoofdstuk werden grote verschillen gevonden tussen Angolezen en Nigerianen. In tegensstelling tot Nigeriaanse ouders verschillen Angolese transnationale ouders significant van niet-transnationale ouders in hun arbeidsdeelname. Angolese transnationale ouders ervaren vaker dat werk en familieleven met elkaar in conflict staan en veranderen vaker van baan (arbeidsinstabiliteit). Deze laatste relatie wordt deels gemedieerd door het feit dat Angolese transnationale ouders aangeven minder gelukkig te zijn. Een mogelijke verklaring voor de bevinding dat Angolese transnationale ouders verhoogde arbeidsinstabiliteit tonen is dat Angolese ouders minder vaak contact opnemen met hun kinderen in het land van herkomst en analyses tonen aan dat dit weer is verbonden aan arbeidsinstabiliteit. Daarom werd geconcludeerd dat transnationale gezinsscheiding op zich niet tot verminderde arbeidsparticipatie leidt, maar alleen als het transnationale gezin gebrekkig functioneert door bijvoorbeeld verminderd contact. 
Eén van de belangrijkste bevindingen van deze dissertatie is dat structurele factoren cruciaal zijn in de studie naar transnationale gezinnen. Hoofdstuk drie heeft aangetoond dat transnationale ouders lagere sociaaleconomische status hebben, vaker ongedocumenteerd zijn en vaker werkloos zijn. Dit toont aan dat het transnationale gezinsleven verbonden is aan andere factoren. Zowel lage sociaaleconomische status als het niet hebben van verblijfsvergunningen beletten fysiek contact en gezinshereniging en kunnen tot verlengde transnationale scheidingen leidden. Daarom tonen de analyses in hoofdstuk vijf aan dat transnationale ouder-kind scheiding geassocieerd is met een lager welzijn, maar dat sommige associaties verdwijnen als sociaaleconomische status en rechtsstatus worden opgenomen. Andere structurele factoren komen naar voren wanneer de Angolezen en Nigerianen worden vergeleken. Sociaaleconomische en rechtsstatus waren vooral belangrijke verklarende factoren voor Nigerianen die als arbeidsmigranten naar Nederland kwamen, maar niet voor Angolezen die als asielzoekers naar Nederland kwamen. Alle hoofdstukken indiceren dat de post-conflict setting in Angola belangrijk is als verklarende factor voor het lagere welzijn van transnationale Angolezen. Ten eerste kan de post-conflict setting en het feit dat asielzoekers niet mogen werken ouders beletten geregeld contact op te nemen met hun kinderen in Angola en zoals hoofdstuk vier aantoonde kan dit de ouder-kind relatie aantasten. Ten tweede is aannemelijk dat een kind achterlaten in een (post) conflict setting extra moeilijk is en dit het negatieve effect van de ouder-kind scheiding kan vergroten.

Concluderend kan worden gezegd dat transnationale scheiding van ouder en kind het welzijn van ouders kan beslechten. Deze studie heeft aangetoond dat een transnationaal gezinsleven voor sommige dimensies van ouderlijk welzijn, zoals geluk voor Nigerianen en mentaal welzijn voor Angolezen, een negatief effect heeft. Ook ouder-kind relaties zijn minder goed in transnationale families en Angolese transnationale ouders vertonen verhoogde arbeidsinstabiliteit. Echter, wat de verschillende hoofdstukken ook aangeven is dat als er goede regelingen zijn getroffen in het transnationale gezinsleven, zoals frequent contact of een goede relatie met de verzorger, transnationale scheiding niet problematisch hoeft te zijn. Bovendien, zoals boven al herhaaldelijk is aangegeven, hangt het functioneren van deze families nauw samen met de context van migratie en vestiging in Nederland. Daarom zou beleid in zowel het land van herkomst als vestiging zich kunnen richten op het verbeteren van de stabiliteit van deze families. Daar zijn verschillende mogelijkheden voor. Zoals dit en ander onderzoek aantoont is contact cruciaal is voor het functioneren van deze gezinnen. Huidig migratiebeleid leidt tot verlengde scheidingen en de hoge visakosten en eisen die gesteld worden aan bezoek maken het moeilijk voor ouders en kinderen om elkaar vaker fysiek te treffen. Voor migranten met een lage sociaaleconomische status en ongedocumenteerden is dit al helemaal onmogelijk. Circulaire migratie, tijdelijke werkvergunningen voor ouders en 
speciale verblijfsvergunningen voor kinderen zouden dit fysieke contact kunnen bevorderen en leiden tot beter welzijn van ouders. Bovendien moet bij beleidsontwikkeling worden stilgestaan bij het feit dat migratiebeleid in het vestigingsland niet alleen effect heeft op migranten in het land van vestiging, maar ook op hun families in het land van herkomst. 

Valorisation addendum 

This dissertation tried to advance our understanding of the effects transnational parentchild separation has on migrant parents' lives. As discussed in the introduction and conclusion, one thing that various studies, including my own, have shown is that transnational families do not exist in a vacuum. They are affected by conditions in the origin and host country; conditions that are shaped by policies and society as a whole. Therefore, it is of crucial importance to understand how these policies shape the lives of these migrants and their family members in the country of origin. Yet not only is it important to look at the effects the conditions in both host and origin countries have on these families, but also at the implications the functioning of these families have for the host and origin country. For example, migrants that have good emotional health and perform well at their jobs contribute more to the economies of the host societies than those who feel emotionally instable. This chapter addresses some of these issues and has as its aim to direct policy makers and other authorities to important factors affecting the functioning of transnational families and give recommendations for policy development. The second part of this chapter summarizes how the project tried to disseminate the results of our research to policy makers, respondents and society as a whole.

\section{$1 \quad$ Policy implications}

First, as already mentioned in the conclusion, research in The Netherlands is predominantly focused on the 'traditional' migrant groups, even though the number of migrants from the 'new' immigrant groups is steadily increasing (Grillo \& Mazzucato, 2008; Wijk van, 2007). Yet, as this dissertation has demonstrated, the conditions these 'new' migrant groups face upon entry and the receiving context are different than for the 'traditional' migrant groups. Therefore it is important to pay particular attention to these new immigrant groups in policy development. For example, the reception by the Dutch government and Dutch society has become more hostile. Consequently, the migration and family reunification policies have become much stricter since the 1970s, which has affected the family life of these 'new' immigrant groups. As this dissertation has shown, one of the challenges that these 'new' immigrant groups face is how to live transnational family life. While in the 'old' migrant groups transnational families were also existent, many of the families had the ability to reunite in The Netherlands through family reunification and formation. Yet, the migration policies in place make this much more difficult for the 'new' immigrant groups. Hence, future policies should be based on the needs and issues that the 'new' immigrant groups face and not only on migrant groups who migrated to The Netherlands three generations ago because these groups face different challenges (Mazzucato, 2008).

Second, in this dissertation I have argued that when studying migrants it is important to take a transnational approach. As discussed in the conclusion, this has some implications for policy development. Governments in the North have regarded transna- 
tional activities as synonymous with limited loyalty to the new country of residence or as a threat to national unity (Bryceson \& Vuorela, 2002; Waldinger \& Fitzgerald, 2004). It is argued that, if time and interests were invested in the host country, this would greatly help immigrants incorporate into the new society (Guarnizo, Portes, \& Haller, 2003; Levitt, 2003). Yet, transnationalism does not necessarily hinder integration. The two are not mutually exclusive (Guarnizo et al., 2003; Levitt \& Jaworsky, 2007; Mazzucato, 2008; Portes et al., 1999; Snel, Engbersen, \& Leerkes, 2006). This dissertation has shown that these transnational activities are of importance for the lives of migrants in the host country.

For instance, what my research has shown is that, for transnational parents, contact with family in the country of origin is key for maintenance of good transnational parent-child relationships and is also of importance for parents' job outcomes in the host country. In addition, good parent-child relationships are found to be consistently associated with improved subjective well-being. In other words, the findings imply that maintaining transnational ties is of crucial importance for the well-being of the parent in the host country. Furthermore, these transnational activities are not only necessary to maintain active family bonds and for improving the well-being of the migrants themselves but are also of vital importance for the emotional and financial well-being of the family members back home. Although not included in this study, research indicates that visits and face-to-face contact are crucial in maintaining affective family bonds. However, strict host country migration policies often prohibit the visits of family members. In conclusion, many migrants will remain engaged both 'here' and 'there', especially where family life is concerned. Therefore, migration and integration policies should not stand in the way of these double engagements, especially because they can better the lives of migrants and their families.

Third, authorities in both the origin and host country should be pointed to the existence of transnational families and the impacts this can have on the well-being of parents and children. However, while various family forms are now recognized in research and policy, such as same-sex marriages, adoption and single parenthood, transnational families have often been neglected. This is exemplified in the feitelijke gezinsband (effective family bond) the Dutch introduced in in 1986. Although this policy has been abolished for over 10 years it does signify how the Dutch long thought about the family as a unit. In short, as explained in chapter 2, the feitelijke gezinsband prescribed that parents who had been separated from their children for an extended period of time lost their right to family reunification. Also, if others besides the parents cared for the child and did not financially support the child, family ties were considered to be broken (Bonjour, 2009). Yet, as this study has shown, physical proximity is not a precondition for family life. Parents actively keep parenting across borders and are therefore an important form of family life. In addition, some parents migrate with the intention to reunite with the family once settled in the host country. However, often- 
times economic and administrative hurdles migrants have to overcome elongate separations, consequently loosing their right to family reunification if the feitelijke gezinsband would be in place. Moreover, restrictive policies of family reunification have not advanced integration (Strik, De Hart, \& Nissen, 2013). Although, by ruling of the European court, the feitelijke gezinsband was abolished in 2006, we should guard that similar policies are not implemented.

Fourth, although transnational family separation is not necessarily problematic this dissertation has also proven that family separation can impede well-being and integration if transnational child raising arrangements do not work well. Policy is crucial here. For example, in the empirical chapters it was established that contact with the children in the country of origin is not only of importance for the maintenance of a good parentchild relationship, but that this can impact emotional well-being and job instability of migrant parents as well and hence the functioning of the migrant in the host society. Although not taken up in the analyses of this dissertation, results of the TCRA projects have shown that visits are of key importance for the well-being of all members of the family and for parent-child relations. European visa policy should allow for easier border crossings of these families, for instance by allowing circular migration through for example temporary work visas or by allowing children to visit their parents through special visas. At present, it is very costly and time consuming to get a visa for these children to visit.

A final lesson to be drawn is the importance of the context of migration. Because of their migration trajectory Nigerians are more often found in a precarious position in The Netherlands, with a large share of undocumented migrants and migrants of low socio-economic status. While for documented parents visits are costly and can be difficult, for many undocumented parents visits are impossible. These parents have nor the resources nor the required papers to cross borders or let their children visit them. In addition, as for parents with low socio-economic status, undocumented parents are not eligible for family reunification leading to elongated separations. Furthermore, these poor and undocumented parents often have difficulty to meet the needs of their families in the country of origin. Therefore, socio-economic and undocumented status stand out in explaining some of the differences found between the well-being of transnational and non-transnational parents. European governments should be aware that their migration policies have these adverse effects not only for migrants but also the family members back home. In addition, it seems that the post-conflict setting in Angola has intensified the effect transnational family separation has on the well-being of these parents. Authorities, such as health workers, should pay special attention to these precarious groups. They should recognize that low socio-economic and undocumented status and trauma from war can interact with other factors and can have a significant impact on the functioning of these families. 
To make my research available to a larger and non-scientific audience, the results of my dissertation have been translated in various forms. This $\mathrm{PhD}$ is based in a larger project in which multiple actions have been undertaken to reach a non-scientific audience. First, the TCRAf-Eu project has its own website ${ }^{14}$ which is aimed at academics, policy makers and the respondents who were part of our research. Academics can find information on our project and links to our publications. In addition, policy makers can find policy briefs. Respondents have their own section which contains important information on the project and some findings. The website further contains information on the researchers, program leaflets with important information, writings of students who participated in a writing workshop, a TV and radio broadcast in which Ghanaian transnational parents were interviewed, and photos and videos that were taken during the course of our project. Also, the site contains an option to contact the project's researchers. Finally, the site contains the questionnaires used and a codebook and researchers can request the dataset through the website.

Second, at the closing conference we have held a policy roundtable in which NGOs, government bodies and media discussed the findings and implications of our project. For this policy round table a document was created to report our main findings. Third, we have written two policy briefs ${ }^{15}$ to communicate our results to policy makers. Fourth, a piece was written by the Principle Investigator for the Internationale Spectator, a magazine for international politics and international relations (Mazzucato, 2013) ${ }^{16}$. Fourth, a newspaper article appeared in the Volkskrant reflecting some of our findings (Bolwijn, 2013) ${ }^{17}$. Finally, I have written two pieces to share my findings with a larger and non-scientific audience. One piece for versvak.nl, a Dutch platform to make science accessible for a non-academic audience (Haagsman, 2014b) ${ }^{18}$, and one piece for NORFACE Compact series (Haagsman, 2014a) ${ }^{19}$, the research programme on migration that funded our project. All these written pieces are available on Internet and through the project website.

\footnotetext{
${ }^{14}$ See www.tcra.nl

${ }^{15}$ See http://fasos-research.nl/tcra/files/2013/05/TCRA-POLICY-BRIEF_def.pdf

${ }^{16}$ See http://fasos-research.nl/tcra/files/2013/05/20130300_internat-spectator_art_mazzucato.pdf

${ }^{17}$ See http://fasos-research.nl/tcra/files/2013/07/Artikel-Marjon-Bolwijn1.pdf

${ }^{18}$ See http://www.versvak.nl/karlijnh/

${ }^{19}$ See http://issuu.com/creamucl/docs/norface2014_migration-paths_of_expl/15?e=4447956/8272800
} 
Curriculum Vitae 

Karlijn Haagsman was born June 1, 1984 in Odijk (The Netherlands). In 2007 she obtained a Master's degree in Cultural Anthropology and Development Studies at the Radboud University Nijmegen. Here she developed a growing interest in transnational migration research, which led her to study return migration to Tonga, an island kingdom in West-Polynesia, for her Master thesis. This interest led her to enroll in the Research Master 'Migration, Ethnic Relations and Multiculturalism' at Utrecht University, which she completed in 2009. The thesis she wrote for this Master focused on the association between intergroup contact and intergroup attitudes in the Russian Federation, and the differences in this association between majority and minority status groups.

In January 2010, Karlijn participated as a Ph. D. researcher in the TCRAf-Eu project focusing on the effects of transnational child-raising arrangements on lifechances of children, migrant parents and caregivers between Africa and Europe, of which this dissertation is the result. During her Ph. D. research Karlijn was a member of CERES, the national research school for Resource Studies of Development in the field of International Development Studies, which is focused at understanding social transformation in light of global interconnectedness and interdependence. At present, Karlijn is employed as a lecturer of Globalization and Development at the Faculty of Arts and Social Sciences of Maastricht University. 


\section{Parenting across borders}

\section{Effects of transnational parenting on the lives of Angolan and Nigerian migrant parents in The Netherlands}

This dissertation is about migrant parents in transnational families, i.e. families whose members live in two or more nation-states and whose kinship ties, as a result, extend across national borders. Although multi-local families have existed for centuries, increased global connections and strict family migration policies have changed the nature and scope of these families. On the one hand, communication technologies and cheaper travel have facilitated better contact across great distances. On the other hand, the greater distances travelled and strict migration policies have created obstacles for reunification and have resulted in protracted separations. The relatively new but burgeoning field of transnational family studies has shown that migrant parents part of transnational families face many challenges and that parent-child separation can have negative consequences for the well-being of migrant parents. This dissertation contributes to this literature by investigating the effects of transnational parenting on the lives of Angolan and Nigerian migrant parents in The Netherlands.

By building on the mainly ethnographic body of transnational family literature, this dissertation tries to advance our understanding of the effects of transnational separation by utilizing survey data that allowed the analysis of various factors identified by previous studies simultaneously. By using survey data and including a group of non-transnational parents, I study the association between transnational parent-child separation and parental well-being, control for confounding factors, investigate specific moderation and mediation effects, and reveal which conditions are of special importance for the well-being of transnational parents. Finally, this study focuses on different aspects of transnational parents' well-being, not all of which have been explored before. Three aspects of parental well-being are investigated that are intrinsically related to each other, namely, the quality of the transnational parent-child relationship, parents' subjective well-being and health, and job outcomes. 